\title{
Galvanic-induced body sway
}

Citation for published version (APA):

Balter, S. G. T. (2004). Galvanic-induced body sway. [Doctoral Thesis, Maastricht University]. Datawyse / Universitaire Pers Maastricht. https://doi.org/10.26481/dis.20040917sb

Document status and date:

Published: 01/01/2004

DOI:

10.26481/dis.20040917sb

Document Version:

Publisher's PDF, also known as Version of record

\section{Please check the document version of this publication:}

- A submitted manuscript is the version of the article upon submission and before peer-review. There can be important differences between the submitted version and the official published version of record.

People interested in the research are advised to contact the author for the final version of the publication, or visit the DOI to the publisher's website.

- The final author version and the galley proof are versions of the publication after peer review.

- The final published version features the final layout of the paper including the volume, issue and page numbers.

Link to publication

\footnotetext{
General rights rights.

- You may freely distribute the URL identifying the publication in the public portal. please follow below link for the End User Agreement:

www.umlib.nl/taverne-license

Take down policy

If you believe that this document breaches copyright please contact us at:

repository@maastrichtuniversity.nl

providing details and we will investigate your claim.
}

Copyright and moral rights for the publications made accessible in the public portal are retained by the authors and/or other copyright owners and it is a condition of accessing publications that users recognise and abide by the legal requirements associated with these

- Users may download and print one copy of any publication from the public portal for the purpose of private study or research.

- You may not further distribute the material or use it for any profit-making activity or commercial gain

If the publication is distributed under the terms of Article $25 \mathrm{fa}$ of the Dutch Copyright Act, indicated by the "Taverne" license above, 
Galvanic-induced Body Sway 
Cover-design: G. van Zonneveld

Printed by: $\quad$ Datawyse BV, Maastricht

ISBN 90-5278-415-9

(c) S. G.T. Balter, Maastricht 2004 


\section{Galvanic-induced Body Sway}

\section{PROEFSCHRIFT}

ter verkrijging van de graad van doctor aan de Universiteit Maastricht, op gezag van de Rector Magnificus, Prof. mr. G.P.M.F. Mols,

volgens het besluit van het College van Decanen, in het openbaar te verdedigen op vrijdag 17 september 2004 om 12.00 uur

door

Susanne Gezina Theodora Balter

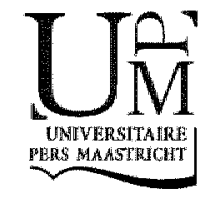


Promotor:

Prof dr. H. Kingma

Compromotor:

Dr. R.J. Stokroos

Beoordelingscommissie:

Prof. dr. H.W.M. Steinbusch (voorzitter)

Dr. L.J.J.M. Boumans (Erasmus Universiteit Rotterdam)

Prof. dr. M. Limburg

Prof. dr. M. Magnusson (University Hospital Lund, Sweden)

Prof dr. J.S.H. Vles

Publication of this thesis was financially supported by:

Entermed, Glaxo Wellcome, Hall Allergy, Mediprof Medical Products, Mestrini, Tefa-Portanje, Schering-Plough, Streukens 


\section{CONTENTS}

List of Abbreviations

Chapter 1: General introduction 7

Chapter 2: Background on methods of stimulation in galvanic-induced body sway in young healthy adults

Chapter 3: Frequency dependence of galvanic vestibular stimulation

Chapter 4: Habituation to galvanic vestibular stimulation

Chapter 5: Habituation to galvanic vestibular stimulation for analysis of susceptibility to carsickness

Chapter 6: Habituation to galvanic vestibular stimulation for analysis of postural control abilities in gymnasts

Chapter 7: Galvanic-induced body sway in vestibular schwannoma patients: evidence for stimulation of the central vestibular system

Chapter 8: Summary and general discussion

Chapter 9: Samenvatting

Acknowledgements

Curriculum Vitae 


\section{LIST OF ABBREVIATIONS}

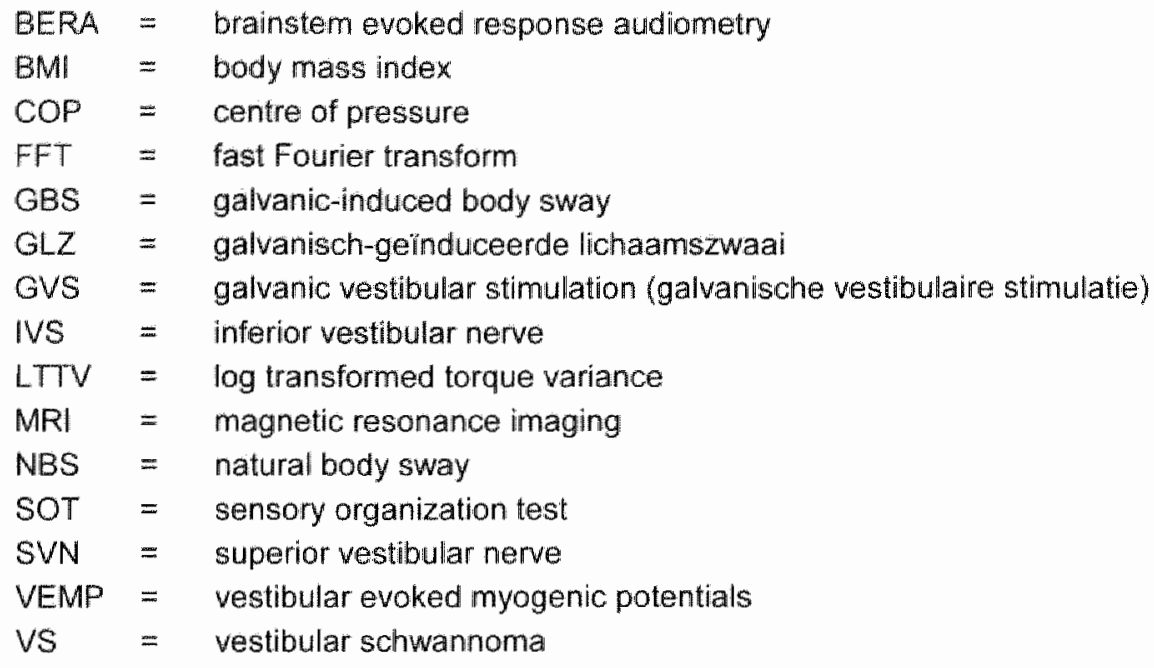


Chapter 1

General introduction 


\section{INTRODUCTION}

This thesis focuses on galvanic (i.e. electrical) vestibular stimulation (GVS), which is a frequently mentioned technique to explore vestibular function. GVS has been used since its discovery by Purkinje in 1820 , but has never become a widely accepted routine clinical measure. GVS is an interesting test procedure as it has been promoted to assess the unilateral peripheral vestibular function and because it is suggested that it discriminates between labyrinthine and retro-labyrinthine function disturbances (1-5). At current, the most frequently mentioned techniques to stimulate the vestibular system are:

\begin{tabular}{|c|c|c|c|c|}
\hline & unilateral & bilateral & canals & statolittus \\
\hline Caloric stimulation & $x$ & & $x$ & \\
\hline Slow angular accelerration & & $x$ & $x$ & $x$ \\
\hline Fast angular acceleration & $x$ & $x$ & $x$ & $x$ \\
\hline Linear acceleration & & $x$ & & $x$ \\
\hline Head roll and thte & & $x$ & $x$ & $x$ \\
\hline Centrifugation & $\times$ & $\mathrm{x}$ & & * \\
\hline Loud sounds (VEMP) & $x$ & & & x \\
\hline Galvanic stimulation & $x$ & $x$ & ? & ? \\
\hline
\end{tabular}

Each of these stimulation techniques has its limitations and disadvantages. All techniques, galvanic stimulation excluded, are believed to stimulate solely labyrinthine structures within the vestibular system. Caloric irrigation of the external auditory canal forms an ipsilateral stimulus of the horizontal canal predominantly allowing quantification of side differences $(6,7)$. Slow to moderate angular acceleration stimulates both canals and statolith organs and does not allow unilateral assessments. Fast head rotations (head impulses) are reported to allow objectivation of side differences of horizontal and vertical canals (8-10). Linear accelerations, rolls and tilts stimulate both labyrinths simultaneously which hamper objectivation of side differences. Only use of an advanced rotatory device equipped with a linear sled allows unilateral centrifugation and a unilateral evaluation of utricular function (11). Statolith organs are unable to discriminate between linear accelerations and rols and tits (12-14). In case of vestibular evoked myogenic potentials (VEMP), the loud clicks or tones are believed to stimulate each sacculus separately (15, 16).

In short, detection of side differences in canal, utricular and saccular function seems to be possible, however unfortunately to our experience all with limited sensitivity. According to the literature (17), galvanic stimulation seems to be the only candidate to localize side differences and discriminate between labyrinthine and retro-labyrinthine disorders (2).

\section{Galvanic vestibular stimulation}

In GVS anodal and cathodal polarizing currents are applied to the mastoids; an electrical current is transmitted through the soft and bony tissues to peripheral neurones in the vicinity of the labyrinth (including Scarpa's ganglion) affecting the neuronal electrical ac- 
tivity locally (Fig. 1) (18-20). Three major factors determine which strucures are located in the electrical field generated and the strength of the electrical field these structures are subjected to: stimulus amplitude and frequency, size and position of the electrodes, and conductivity of the various tissues.

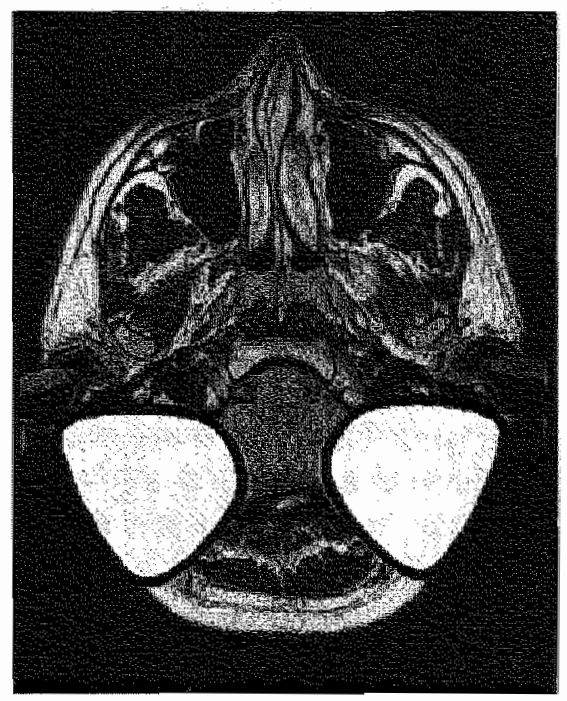

Figure 1: MRI-scan with supposed generated electrical field

The responses described most frequently are eye movements (e.g. nystagmus), body sway, facial muscle activation and subjective sensations (e.g. movement, dizziness, nausea, tingling of the skin at the site of stimulation, taste sensations, light flashes in the temporal visual field) $(1,21-30)$. Previous research and clinical applications have been limited by the requirement for relatively high, sometimes painful, electrical currents to produce recordable horizontal eye mowements (31). More recent studies using lower intensity currents while recording non-horizontal (i.e. torsional) eye movements (2, 32) or posturall movements (22) have led to renewed interest in this technique. However, all llow and convenient stimulus intensities galvanic-induced eye movements are very small and need special patient unfriendly equipment to be detected (search coil technique) (33). Therefore, our study was designed to investigate galvanic-induced body sway (GBS), which shows relatively easy to measure responses at low stimulus intensities. Several papers on GBS investigate the mechanisims and pathways of the glalvanic response (19. 21, 34-41). GBS is typically towards the side of positive (anodal) stimulation and away from the side of negative (cathodal) stimulation $(21-24,30,35,42-44)$. The direction of postural response induced by GVS depends on the head and trunk position, which is however a complicated mechanism $(23,42,45-48)$. It is not certain which parts of the vestibular system are responsible for the postural movements induced by the galvanic stimulus. Literature describes that the most likely site of primary excitation is thought to 
be Scarpa's ganglion, where a positive current is believed to decrease the spontaneous neuronal firing rate and a negatwe current increases it $(18,19,38)$. It is not unlikely that the electrical current is exciting the vestibular nerve (including Scarpa's ganglion) and also more centrally located vestibular structures (vestibular nuclei, cortical areas) directly. The actual conduction course of GVS thus remains uncertain.

Stimulation of the vestibular nerve involves the utriculo-ampular and the sacculoampular nerve. The utriculo-ampullar nerve (superior vestibular nerve) originates in the cristae of the utricle and in the superior and horizontal semi-circular canals. The three bundles thus formed unite and join the sacculo-ampullar nerve (inferior vestibular nerve) that originates in the cristae of the saccule and the inferior semi-circular canals. Then both nerves proceed lo Scarpa's westibular ganglion. From here the superior and inferior vestibular nerve pass through the internal auditory canal together with the cochlear and facial nerve. In the further course at the level of the medulla oblongata the vestibular nerve and its nuclei lie slightly dorsal to the cochlear nerve and its nuclei.

in GVS nystagmus, body sway and subjective sensations (e.g. movement, dizziness, and nausea) can be explained by stimulation of the vestibular system, which is contained in the electrical field. The same holds for facial muscle activation, which can be elicited by direct stimulation of the facial nerve. Tingling at the side of stimulation can be explained by stimulation of the greater auricular nerve, together with branches of the lesser occipital nerve. No auditory sensations are mentioned in literature, which may be explained by the fact that the auditory system mainly reacts to higher frequency stimulation than the one generally used in GVS $(<10 \mathrm{~Hz})$.

\section{Future aspects for GVS application}

Until now some basic problems hindered a wide clinical application of GVS. First, an increase of the stimulation threshold has been mentioned to point to a partial nerve lesilon but also to a normall high basic electrical resistance of the temporal bone (4). Second, response decline that occurs upon repetitive GVS (49) could hamper clinical evaluations on the long term.

Concluding, no standardized procedures with respect to galvanic stimulation and analysis of response have been established so far. In this thesis development of a standardized procedure for a reproducible quantification of GBS is described. Basically, the side and localization of galvanic stimulation is explored in detail to evaluate its possible clinical relevance. The possible clinical applications of the test-procediure introduced are evaluated by testing healthy subjects and various sub-populations including subjects suffering from carsickness, professional gymnasts and vestibular schwannoma-patients. 


\section{CONTENTS OF THIS THESIS}

This thesis contains six chapters that were originally written as separate manuscripts. Below a brief description of the contents of each chapter is given.

Chapter 2: Background on methods of stimulation in galvanic-induced body sway in young healthy adults

The development of a standardized procedure for a reproducible quantification of GBS is described. Sixty subjects undergo computer controlled GVS using a 1-cosinusoidal stimulation of $0.5 \mathrm{~Hz}$ and $2 \mathrm{~mA}$. Short-term habituation and reproducibility are evaluated.

Chapter 3: Frequency dependence of galvanic vestibular stimulation

In twelwe healthy subjects the GBS is studied as a function of the stimulus frequency and amplitude to define the optimal stimulus conditions for further exploration of the GBS.

Chapter 4: Habituation to gavanic vestibular stimulation

In this study we evaluate possible long-term habituation to repetitive GVS that might hamper clinical evaluations on long term. GBS is quantified in forty subjects at five consecutive moments. Subjects are subdivided in four groups (each group containing ten subjects) and tested with four different time-intervals between the five measurements, ranging from one day to two weeks.

Chapter 5: Habituation to galvanic vestibular stimulation for analysis of susceptibility to carsickness

In this study the possible correlation between the degree of short-term habituation to GVS and susceptibility to carsickness is evaluated. Twelve healthy female subjects versus twelve female subjects suffering from carsickness are tested using a five-time repetition of a binaural 1-cosinusoidal stimulus of $0.5 \mathrm{~Hz}$ and $1 \mathrm{~mA}$. Sensitivity to and habituation of the GBS in these two populations are compared.

Chapter 6: Habituation to gatvanic vestibular stimulation for analysis of postural control abilities in gymnasts

In this study the passible correlation between postural control abilities in gymnasts and the sensitivity for and the degree of short-term habituation to GWS is studied. Seven balance trained young girls versus seven non-trained girls and twenty-five women undergo GVS, according to protocol (monaural continuous 1-cosinusoidal stimulus of 0.5 $\mathrm{Hz}$ and $2 \mathrm{~mA}$, repeated three times on each side). Sensitivity to and habituation of the GBS in these three populations are compared.

Chapter 7: Galvanic-induced body sway in vestibular schwannoma patients: evidence for stimulation of the central vestibular system

Twenty-three vestibular schwannoma-patients are tested before and twelve patients after surgical intervention (extirpation of tumour with concomitant vestibular neurectomy) versus forty-seven healthy subjects. The impact of the presence of a vestibular schwan- 
noma and the surgical intervention upon GBS is analyzed to identify possible sites of excitation by the galvanic stimulus.

Chapter 8: Summary and general discussion

In this chapter the results of research described in this thesis are summarized and discussed in general terms.

Chapter 9: Summary in Dutch 


\section{REFERENCES}

1. Watanabe $Y$, Mizukoshi $K$, Oni $H$, Yasuda $K$, Onasi $N$, Kobayashi $H$. Retro-labyrinthine disorders detected by galvanic body sway response in routine equilibrium examinations. Acta Otom Laryngol. Suppl. 1989;468:343-348.

2. Schneider $E$, Glasauer $S$, Dieterich M. Central processing of human ocular torsion analyzed by galvanic vestibular stimulation. Neuroreport 2000;11(7):1559-63.

3. Brackmanm $T$, Ranft $U$. Zum stellenwert der galvanischen gleichgewichtsprüung. HNO 1989;37:174-178.

4. Pfaltz CR. [Proceedings: Studies on the diagnostic significance of the galvanic test in acoustic neurinoma]. Arch Klin Exp Ohren Nasen Kehlkopfheilkd 1973;205(2):130-4.

5. Pfaltz $C R$, Koike Y. Galvanic test in central vestibular lesions. Acta Otolaryngol $1968 ; 65(1): 161$ 8.

6. Bohmer $A$, Straumann $D$, Kawachi $N$, Arai $Y$, Henn $V$. Three-dimensional analysis of caloric nystagmus in the rhesus monkey. Acta Otolaryngol 1992;112(6):916-26

7. Poilici I, Crighel E. Polygraphic method of investigation of the complex reactivity to slight caloric vestibular stimulation. Electroencephalogr Clin Neurophysial 1969;27(6):638-9.

8. Halmagyi GM. Aw ST, Cremer PD, Curthoys IS. Todid MJ. Impulsive testing of individual semicircular canal function. Ann N Y Acad Sci 2001;942:192-200.

9. Halmagyi GM, Black RA, Thurtell MJ "Curthoys IS. The human horizontal vestibulo-ocular reflex in response to active and passive head impulses after unilateral vestibular deafferentation. Ann NY Aciad Sci 2003;1004:325-36.

10. Cremer PD, Halmagyi GM, Aw ST, Curthoys IS, McGarvie LA, Todd MJ, et al. Semicircular canal plane head impulses detect absent function of individual semicircular canals. Brain 1998;121 (Pt 4):699-716.

11. Clarke $\mathrm{AH}_{\mathrm{v}}$ Engelhorn $\mathrm{A}$. Unilateral testing of utricular function. Exp Brain Res 1998;121(4):457 64.

12. Angelaki DE, Wei $M$, Merfeld DM. Vestibular discrinination of gravity and translational acceleration. Ann N Y Acad Sci 2001;942:114-27.

13. Groen $E$, Bos $、 \mathbb{E}$, de Graaf $B$. Contribution of the otoliths to the human torsional vestibulomacular reflex. J Vestib Res 1999;9(1):27-36.

14. Groen $E$, Bos J, de Graaf $B$, Bles W. Otolith signal processing and motion sickness. Ann $N Y$ Acad Sci 1999;871:406-9.

15. Bacsi AM, Watson SR, Colebatch $J G$. Galvanic and acoustic vestibular stimulation activate different populations of vestibular afferents. Clin Neurophysial 2003;114(2);359-65.

16. Welgampola MS, Rosengren SM. Halmagyi GM, Colebatch JG. Vestibular activation by bone conducted sound. J Neurol Neurosurg Psychiatry 2003; 74(6);771-8.

17. Tsutsumi T, Komatsuzaki A. An adequate parameter evaluating the galvanic body sway test: comparison with the caloric test in patients with vestibular schwannomas. The Journal of Laryngology and otology 1999;113:118-121. 
18. Goldberg JM, Smith CE. Fenandez C. Relation between discharge regularity and responses to externally applied galvanic currents in vestibular nerve afferents of the squirrel monkey. $J$ Neurophystol 1984:51(6):1236-56.

19. Courjon JH. W. P. D.W. S. Vestibular nerve and nuclei unit responses and eye movement responses to repetitive galvanic stimulation in the labyrinth in the rat. Exp Brain Res $1987 ; 66: 41-8$.

20. Watson $S R$, Colebatch JG. EMG responses in the soleus muscles evoked by unipolar gatwanic vestibular stimulation. Electroencephallogr Clin Neurophysiol 1997;105(6):476-83.

21. Britton TC, Day BL. Brown P, Rothwell JC. Thompson PD, Marsden CD. Pastural electromyographic responses in the arm and leg following galvanic vestibular stimulation in man. Exp Brain Res 1993;94(1):443-51

22. Cass SP, Redfern MS, Furman JM, DiPasquale JJ. Galvanic -Induced posturall movements as a test of vestibular function in humans. Laryngoscope 1996:106:423-430.

23. Lund $S$, Broberg $C$. Effects of different head positions on postural sway in man induced by a reproducible vestibular error signal. Acta Physiol. Scand. 1983,117:307-309.

24. Coats AC. Effect of varying stimulus parameters on the galvanic body-sway response. Ann Otol Rhinol Laryngol 1973;82(1):96-102.

25. Coals AC. Limit of normal of the galvanic body-sway test. Ann. Otol. 1972;81:410-416.

26. Sekitani T. Differential diagnosis of vertigo-combined galvanic test and MRI. Acta Otalaryngol Suppl 1988;458:113-9.

27. Tokita T, Ito $Y$. Takagi K. Modulation by head and trunk positions of the vestibulo-spinal reflexes evoked by galvanic stimulation of the labyrinth. Observations by labyrinthine evoked EMIG. Acta Otolaryngial 1989; 107(5-6):327-32.

28. MacDougall HG, Brizuela AE, Burgess AM, Curthoys IS. Between-subject variability and withinsubject reliability of the human eye-movement response to bilateral galvanic (DC) vestibular stimulation. Exp Brain Res 2002;144(1):69-78.

29. Brantberg K. Magnusson M. Galvanically induced asymmetric optokinetic after-nystagmus. Acta Otolaryngoll 1990;110(3-4):189-95.

30. Okami K, Sekitani T, Ogata M, Matsuda $Y$, Ogata $Y$, Kanaya $K_{*}$ et al. GABA distribution in the central vestibular system after retroauricular galvanic stimulation. An immunohistochemical study. Acta Otolaryngol Suppl 1991:481:150-2

31. Moore DM, Hotfman LF, Beykirch K, Honrubia V, Baloh RW. The electrically evoked vestibulo. ocular reflex: I. Normal subjects. Otolaryngol Head Neck Surg 1991;104(2):219-24.

32. Kleine JF, Guldin WO, Clarke AH. Variable otolith contribution to the galvanically induced vestibulo-ocular reflex. Neuroreport 1999;10(5):1143-8.

33. Severac Cauquil A, Faldon M, Popov K, Day BL, Bronstein AM. Short-latency eye movements evoked by near-threshold galvanic vestibular stimulation. Exp Brain Res 2003;148(3):414-8.

34. Day BL, Pastor MA, Bartolomei L, Bonato $C$. Influence of conflicting sensory information on vestibular-induced postural adjustments in man. Jpn I Physiol 1995;45(2):\$333.

35. Day BL. Severac Cauquil A, Bartolomei L, Pastor MA, Lyon IN. Human body-segment tilts induced by galwanic stimulation: a vestibularly driven balance protection mechanism. $₫$ Physiol 1997;500 ( Pt 3):661-72. 
36. Johansson R, Magnusson M. Fransson PA. Galvanic vestibular stimulation for analysis of pos: tural adaptation and stability. IEEE Trans Biomed Eng 1995; $42(3), 282-92$.

37. Coats AC. The sinusoidal galvanic body-sway response. Acta Otolaryngol 1972;74(3):155-62.

38. Lowenstein OJ. The effect of galvanic polarization on the impuse discharge from sense endings in the isolated labyrinth of the thomback ray (raja clawiata). Physiol 1955:127:104 17.

39. Goldberg $J M$, Fernandez $C$, Smith $C E$. Responses of vestibular-nerve afferents in the squirrel monkey to externally applied galvanic currents. Brain Res $1982 ; 252(1): 156-60$.

40. Inglis IT, Shupert CL, Hlavacka F, Horak FB. Effect of galvanic vestibular stimulation on human postural responses during support surface translations. I Neurophysiol 1995:73(2):896-901

41. Petersen H, Magnusson M. Fransson PA, Johansson R. Vestibular stimulation perturbs human stance also at higher frequencies. Acta Otolaryngol Suppl 1995:520 Pt 2:443-6.

42. Nashner $L M_{0}$ Wolfson $P$. Influence of head position and proprioceptive cues on short latency postural reflexes evoked by galvanic stimulation of the human labyrinth. Brain Res. $1974 ; 67(2): 255-68$

43. Fitzpatrick R, Burke D, Gandevia SC. Task-dependent reflex responses and movement illusions evoked by galvanic vestibular stimulation in standing humans. J Physiol 1994:478 (Pt 2):36372.

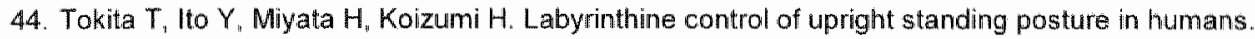
Prog Brain Res 1988;76:291-5.

45. Pastor MA, Day BL. Marsden CD. Vestibular induced postural responses in Parkinson's disease. Brain 1993;116 ( Pt 5): 1177-90.

46. Fransson PA, Karlberg M. Sterner T, Magnusson M. Direction of galvanically-induced vestibullopostural responses during active and passive neck torsion. Acta Otolaryngol 2000;120(4):500-3.

47. Hlavacka F, Njiokiktjien C. Postural responses evoked by sinusoidal galvanic stimulation of the labyrinth. Influence of head position. Acta Otolaryngol 1985;99(1-2):107-12.

48. Noda T, Nakajima $S$, Sasano T, Shigeno K. Importance of cervical muscles in galvanic body sway test. Acta Otolaryngol Suppl 1993;503:191-3.

49. Hlavacka $F$. Njiokiktijien $C$. Sinusoidal galvanic stimulation of the labyrinths and postural responses. Physiol Bohemostow 1986;35(1):63-70. 



\section{Chapter 2}

\section{Background on methods of stimulation in galvanic-induced body sway in young healthy adults}

Susanne G.T. Balter, Robert J. Stokroos, Iwan De Jong "Rob Boumans, Maikel Van De Laar, Herman Kingma

Acta Otolaryngol 2004:124(3):262-71 


\section{ABSTRACT}

The aim of this study was to develop a standardized procedure for a reproducible quantification of galvanic-induced body sway (GBS). This was a prospective experimental study conducted in a tertiary referral centre. An exploratory study was first conducted to define the galvanic vestibular stimulation (GVS) method that resulted in the best reproducible responses. Ten subjects underwent computer-controlled GVS using 5 different types of monaural and binaural stimulation with 2-mA currents. Cosinusoidal stimulation gave the most reproducible responses. The frequency and current variability of this stimulus type were then tested in the same 10 subjects. A monaural continuous 1 cosinusoidal current of $0.5 \mathrm{~Hz}$ and $2 \mathrm{~mA}$ gave the most reproducible responses $<20 \%$ testmetest variation) and the largest GBS amplitude. The other (sinusoidal) stimuli resulted in variabilities exceeding $50 \%$. This stimulus was thus used for further testing in our normative study. In this study we measured GBS amplitude at $0.5 \mathrm{~Hz}$ in 60 subjects, with eyes closed and an inter-feet distance of $0 \mathrm{~cm}$, using a force platform. In addition to body sway, responses included slight dizziness, taste sensations and a tingling sensation at the site of stimulation. Habituation to the applied stimulus was seen. Binaural prestimulation, performed in 50/60 test subjects, is necessary to reduce habituation and achieve optimal reproducibility in order to be able to compare the sensitivity of the left and right vestibular systems. The test-retest variability was determined in detail in 12 additional subjects. Prestimulation reduced habituation, but improved the sensitivity of the method; some test-retest variability persisted $(<20 \%)$.

Key wards: galvanic vestibular stimulation, prospective study, standardized procedure, habiluation

\section{INTRODUCTION}

As early as 1820, Purkinje applied a small direct current to humans and animals through the mastoid and observed symptoms of dizziness and imbalance, pointing to a stimulation of the vestibular system. Bárány confirmed these abservations (1). The responses described most frequently are nystagmus, body sway, facial muscle activation and subjective sensations (e.g. movernent, dizziness, nausea and tingling of the skin at the site of stimulation) (1-7). The mechanisms and pathways of the galvanic response have been investigated in several papers on galvanic-induced body sway (GBS) (4, 8-14). In general, the electrical current is transmitted through the soft and bony tissues to peripheral neurones in the vicinity of the labyrinth (including Scarpa's ganglion) that affect the neuronal electrical activity locally (8). The most likely site of primary excitation is thought to be Scarpa's ganglion, where a positive current is believed to decrease the spontaneous neuronal firing rate and a negative current to increase it $(8,13,15)$. GBS is typically towards the side of positive (anodal) stimulation and away from the side of negative (cathodal) stimulation $(1,3-5,16)$. The direction of postural response induced by GVS depends on the head and trunk position, which is, however, a complicated mechanism ( 3 , 
16-18). Sway amplitude increases with increasing stimulus amplitude $(5,9)$, if body stability is decreased (for example by putting the feet together). proprioceptive input reduced (standing on foam rubber) or visual orientation reduced (eyes closed) $(9,11,16)$. When a sinusoidal stimulus is applied the maximum GBS is seen at frequencies between $0.025-0.2 \mathrm{~Hz}$ (12). The stimulus has been proven to bypass the labyrinth and might therefore be used to discriminate between end-organ lesions and vestibular nerve lesions $(2,8)$. However, a basic problem has hindered a wide clinical application of the technique: an uncrease of the stimulation threshold might point to a partial neve lesion but also to a normal high basic electrical resistance of the temporal bone. No standardized procedures have been established so far with respect to stimulation and analysis of response. The following aspects may have hindered standardization and broad clinicall acceptance. First, the responses seem to vary considerably between healthy subjects, which results in normative data with large variability $(3,6,19)$. Second, the exact site at which stimulation occurs and the pathways inwolved in the evoked responses are not fully understood, which complicates clinical interpretation of absent or abnomal responses $(4,9)$. Third, GVS with currents exceeding $1-2 \mathrm{~mA}$, which are needed to ellicit a nystagmus, is known to be painful or to induce skin tingling $(1,5,9,10)$. Finally, GVS is known for its decline in response during repetitive measurements. Habituation to vestibular stimulation is a well-known phenomenon, observed for example during repeated velocity step experiments (20) and repeated caloric irrigation (21). Single-neuron studies suggest that the decline in response is produced not only by inherent mechanisms in the end organs or vestibular nuclei but rather may involve more complicated neuronal reflex pathways situated downstream from the vestibular nuclei (22). The aims of this study were to find the most appropriate stimulus for inducing body sway and a reproducible GVS method to provide normative GBS data.

\section{MATERIALS AND METHODS - Exploratory study}

\section{Subjects}

Ten healthy subjects were tested ( 4 males, 6 females, mean age 26.1 years, range 20 33 years). Subjects with a history of better-than-average motor or balance skills (ballet dancers, gymnasts, and semi-professional sportsmenl and those with a history of vestibular, musculoskeletal or neurological complaints were excluded. Subjects did not use any medication that could affect the vestibular or musculloskeletal system. Alcohol consumption was prohibited for $24 \mathrm{~h}$ prior to testing.

\section{Materials}

A computer-controlled stimulator, built in our department and meeting the appropriate safety regulations. (IEC 601.1). generated the types of galvanic stimulus described be 
low. The stimulator is provided with a feedback mechanism so that an identical galvanic stimulus can be applied to every subject tested, irrespective of the electrical conductivity of skin and temporal bone. The electrodes measure $50 \times 35 \mathrm{~mm}^{2}$ and are composed of sillicon rubber, mixed with conducting carbon particles (CEFAR M Medical Products, Lund, Sweden). The electrodes were attached to the retro-auricular skin with electroconductive adhesive gel (Tac Gelrm). Movements of the centre of pressure (COP) were measured using a force platform

$\left(42 \times 35 \mathrm{~cm}^{2}\right.$; Jaeger-Toennies $\mathrm{GmbH}$, Wurzburg. Germany) equipped with four transducers, one at each corner. Data-acquisition ( $50 \mathrm{~Hz}$ sampling rate) and analysis were performed using a T-Post-Nystagliner computer system (Jaeger-Toennies GmbH).

\section{Procedure}

Prior to testing the retro-auricular skin was cleaned with petroleum-ether and Tac Gel ${ }^{\text {rm }}$ applied to three electrodes. The gell was allowed to dry for five min to improve adhesion to the skin. No subjective sensations were reported or significant GBS detected when the "active" electrodes were placed on the forehead, upper trunk or neck. We placed two electrodes at the mastoid, one behind each ear. A third electrodle was placed on the meck at the $\mathrm{C} 7$ vertebra (Fig. 1).
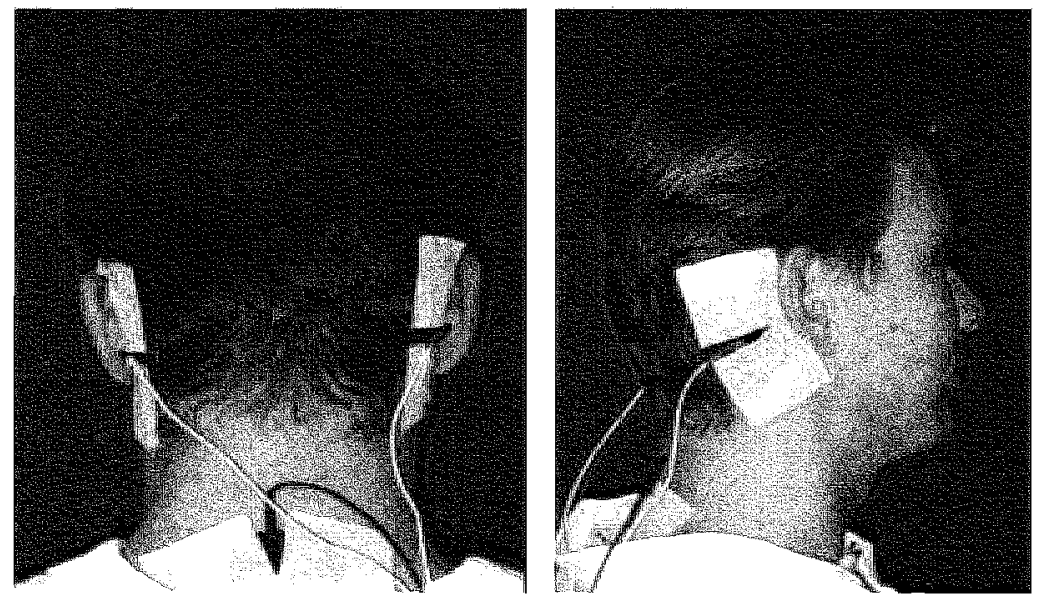

Figure 1: Position of the electrodes

In the case of monaural stimulation the retro-auricular electrodes were used as positive electrodes and the neck electrode as a negative electrode. The electrodes were fixed with adhesive tape (Mefix(B). In order to optimize retro-auricular stabilization of the electrodes and reduce auditory spatial orientation a headphone was worn by the sulbject. During each lest, lights in the test-cabin were dimmed and the subject's eyes closed to prevent any visual orientation. Each subject was instructed to stand upright with bare closed feet (inter-feet distance $5 \mathrm{~cm}$ ) on the force platform and with the arms crossed in front of the body ( $0 \mathrm{~cm}$ feet distance in the normative study). The test cabin was provided 
with a frame surrounding, which did not touch the subject, to prevent a fall in the case of severe imbalance. Using a questionnaire, all subjects were asked (in between the tests) to report possible test-related sensations, such as pain or tingling sensations at the eletrode positions, abnormal taste sensations, dizziness or sensation of movement. First the 5 test conditions (shown in Figs. 2-6) were completed (binaural and monaural test conditions 1-4 (Figs. 2-5) were repeated 20 times and the mean response amplitude calculated.

Next, test condition 5 (Fig. 6) was tested in detail in the 10 subjects. First, stimulus frequency variability was tested $(0.2 ; 0.5 ; 1.5 ; 2.0 ; 3.0$ and $4.0 \mathrm{~Hz})$. Following this, stimulus amplitude variability was tested $(0.2 ; 0.5 ; 0.7 ; 1.0 ; 1.5$ and $2.0 \mathrm{~mA})$.

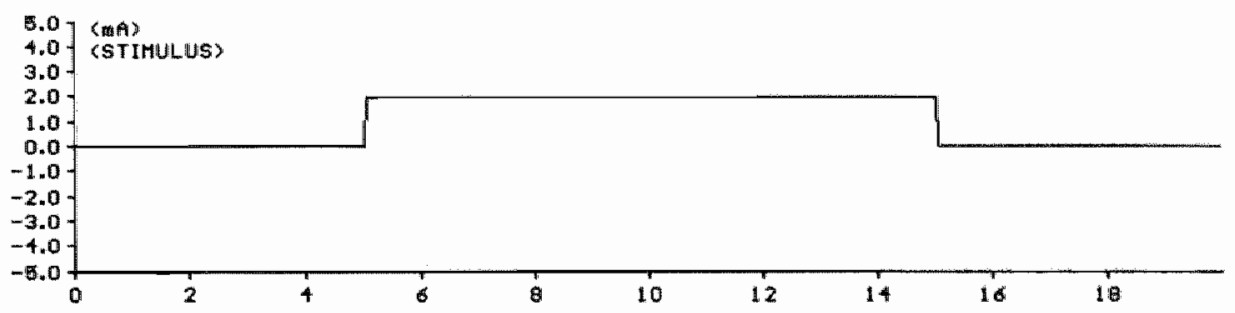

Figure 2: Test condition 1: block stimulation "duration of stimulus: $10 \mathrm{sec}_{\text {" stimulus interval: } 10}$ sec, rise and fall times: 20 msec, stimulus amplitude: $2 m A, 20$ stimuli.

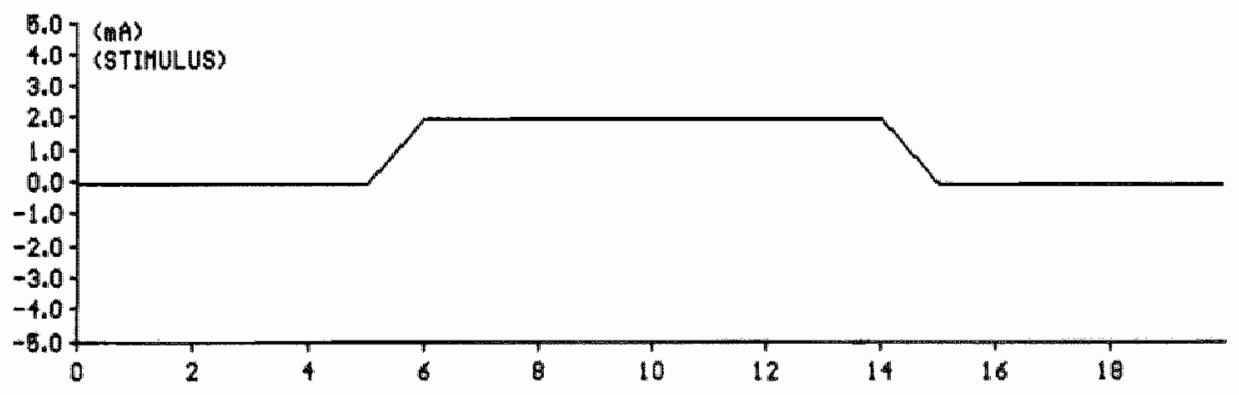

Figure 3: Test condition 2: trapezoidal stimullation, duration of stimulus: 10 sec, stimulus interval: 10 sec. rise and fall times: $1 \mathrm{sec}$. stimulus amplitude: $2 \mathrm{~mA}, 20$ stimuli.

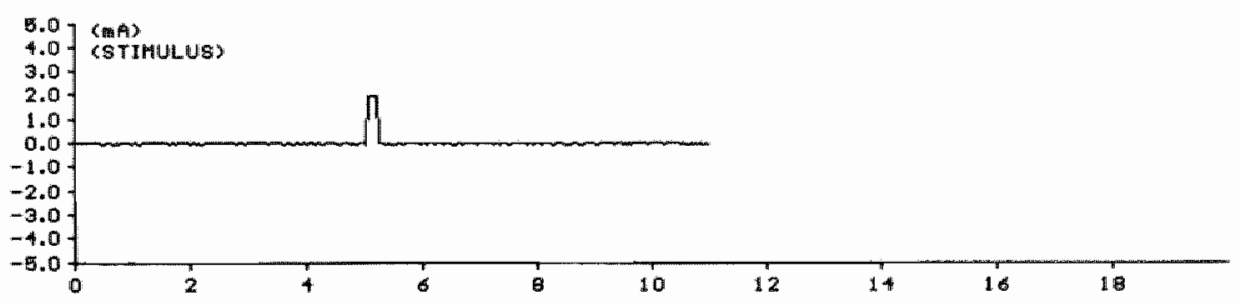

Figure 4: Test condition 3: short pulse stimulation, duration of stimulus: 200 msec, stimulus interval: $10 \mathrm{sec}$, rise and fall times: 20 msec, stimulus amplitude: $2 \mathrm{~mA}, 20$ stimuli. 


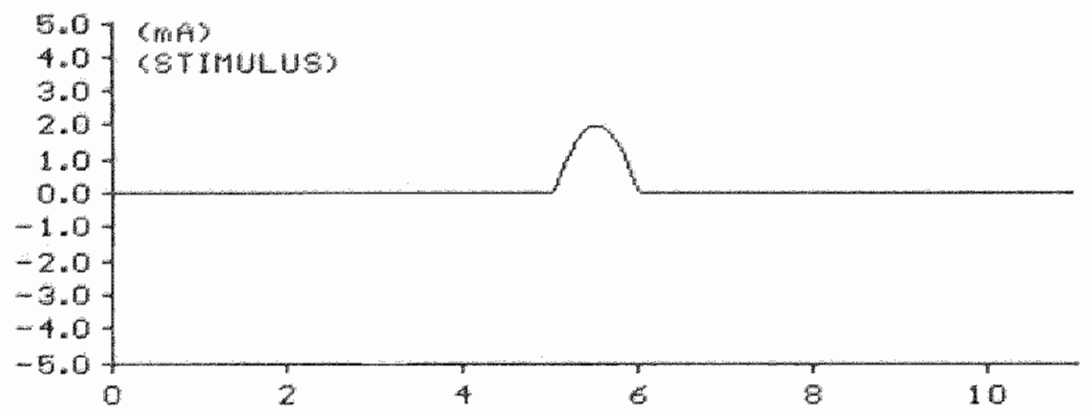

Figure 5: Test condition 4: 1-cosinusoidal stimulation (0.5 period) of $0.1 \mathrm{~Hz}, 0.2 \mathrm{~Hz}, 0.5 \mathrm{~Hz}$ and $1.0 \mathrm{~Hz}$ (example $=1.0 \mathrm{~Hz}$ ), duration of stimulus varies with frequency of stimulation. stimulus interval: $10 \mathrm{sec}$, stimulus amplitude: $2 \mathrm{~mA}, 20$ stimuli.

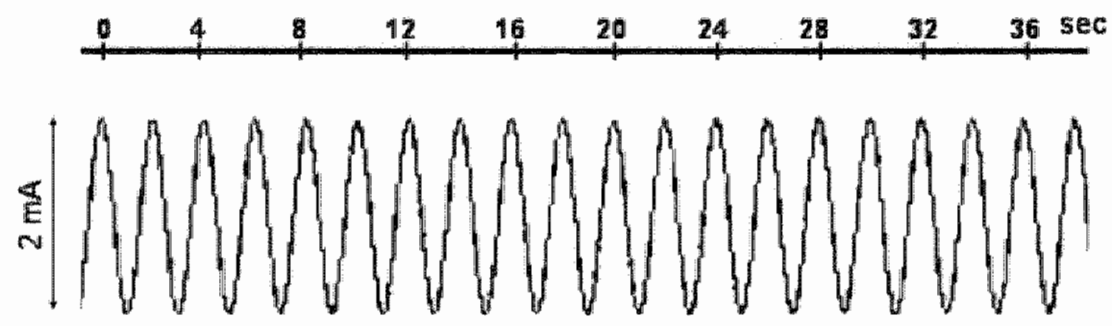

Figure 6: Test condition 5: continuous 1-cosinusoidal stimulation/ frequencies ranging from 0.2 . $4.0 \mathrm{~Hz}$, duration of stimulus: $40 \mathrm{sec}$, stimulus amplitude ranging from $0.2-2.0 \mathrm{~mA}$ (example $=0.5 \mathrm{~Hz}$ and $2 \mathrm{~mA}$ ).

\section{MATERIALS AND METHODS - Normative study}

\section{Subjects}

A total of 72 healthy subjects participated in the normative study after giving their informed consent. Ten healthy subjects were tested without prestimulation ( 5 males, 5 females, mean age 23.5 years, range $20-27$ years), and 50 healthy subjects with prestimulation (25 males, 25 females, mean age 26.0 years, range 20-62 years). Exclusion criteria were identical to those in the exploratory study.

Finally, another 12 healthy male subjects were tested binaurally (mean age 27.8 years, range 21-61 years) to study test-retest and inter-subject variability. 


\section{Materials}

The materials used were identical to those in the exploratory study.

\section{Procedure}

The pre-test procedure was identical to the exploratory study. Continuous 1-cosinusoidal stimulation at $0.5 \mathrm{~Hz}$ and $2 \mathrm{~mA}$ was selected for a detailed analysis of GBS in 60 healthy subjects, generating normative data.

The following test sequence is used in this sample:

First, the natural body sway (NBS) of each subject was measured without any stimulation for $40 \mathrm{~s}$ (zero reference). Next, 50 subjects received a prestimulus consisting of a 40-s continuous binaural sinusoidal $0.5-\mathrm{Hz}$ stimulation of $1 \mathrm{~mA}$. In the 10 remaining subjects no prestimulation was applied. Finally, all subjects $(n=60)$ were stimulated on the left and right sides alternately 3 times using a $40-\mathrm{s}$ continuous 1 -cosinusoidal $0.5-\mathrm{Hz}$ stimulus of $2 \mathrm{~mA}$. In the final study each subject $(\mathrm{n}=12)$ received a binaural prestimulus, followed by 2 binaural test stimuli. The lateral GBS was measured in each of these test sequences. In between sequences, subjects were asked for their subjective sensations (as mentioned above) in relation to GVS.

\section{Data analysis}

Anterior-posterior and lateral sway were expressed in degrees to normalize the displacement of the COP for body length:

$$
\text { Body sway }\left({ }^{\circ}\right)=\operatorname{cotan}[\operatorname{COP} /(0.56 \times \text { body length })]
$$

Here we assume that the centre of body mass is positioned on average at a point $56 \%$ along the length of the body (23). The frequency spectrum of the time series is calculated by fast Fourier transform (FFT) using a Hamming filter and 2048-point window. The frequency spectrum acquired with stimulation is then corrected for the background noise and NBS by subtracting the frequency spectrum acquired without stimulation. Subsequently, the average amplitude of the difference spectrum is calculated at the stimulus frequency (seven classes wide of the discrete Fourier spectrum), taken as the typical response and normalized relative to the stimulus amplitude (in milliamperes). The response is expressed in degrees per milliampere. The phase difference between stimulus and response was also calculated from the Fourier spectra (difference spectrum of the response compared to spectrum of the stimulus).

Statistical analysis (Mann-Whitney U-test and Wilcoxon signed pairs) was performed using SPSS software (version 9.0; SPSS inc., Cary, NC). 


\section{RESULTS}

\section{Placebo effect or non-vestibular responses}

The "reference" electrode was always placed on the neck at the $C 7$ vertebra. No subjective sensations were reported or significant GBS detected when the "active" electrodes were placed on the forehead, upper trunk or neck. GBS was only observed when the active electrodes were placed on the retro-auricular skin and was always directed towards the positive electrode.

\section{Optimal stimulus}

The different types of stimulation (test conditions 1-5) resulted in typical responses as displayed in Figs. 7-12.

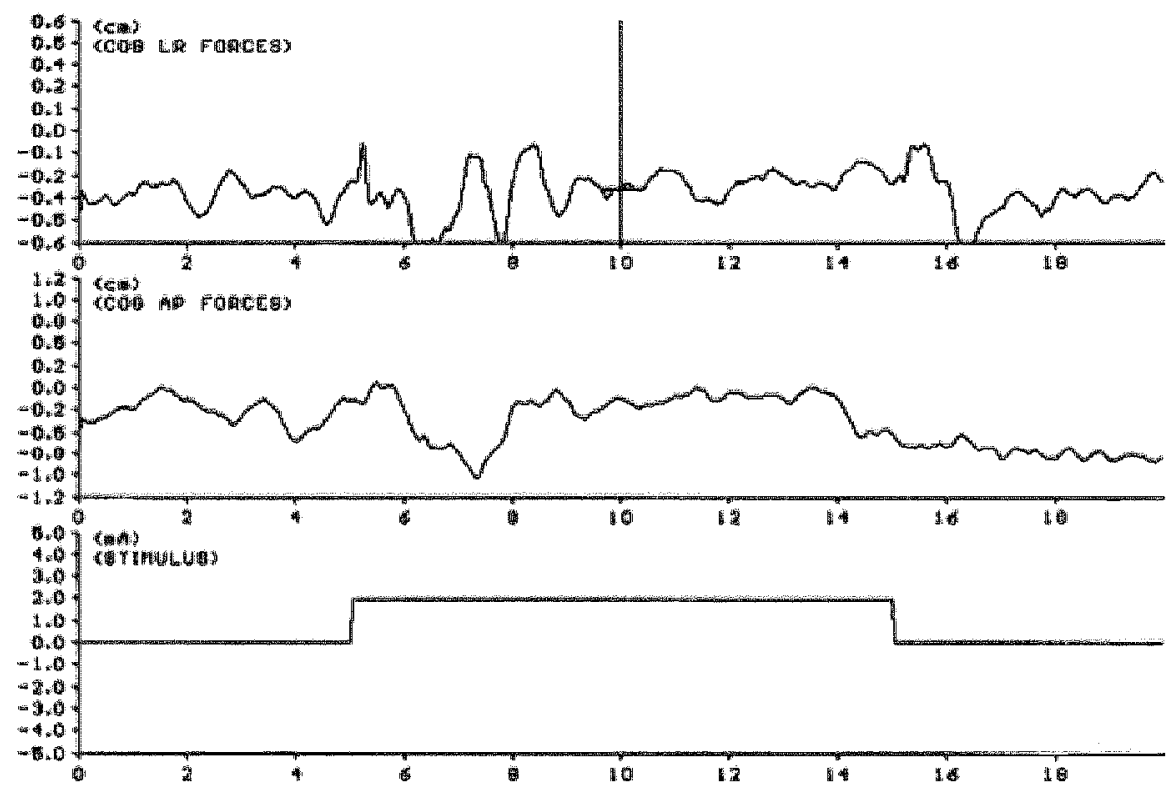

Figure 7: Response block stimulation 


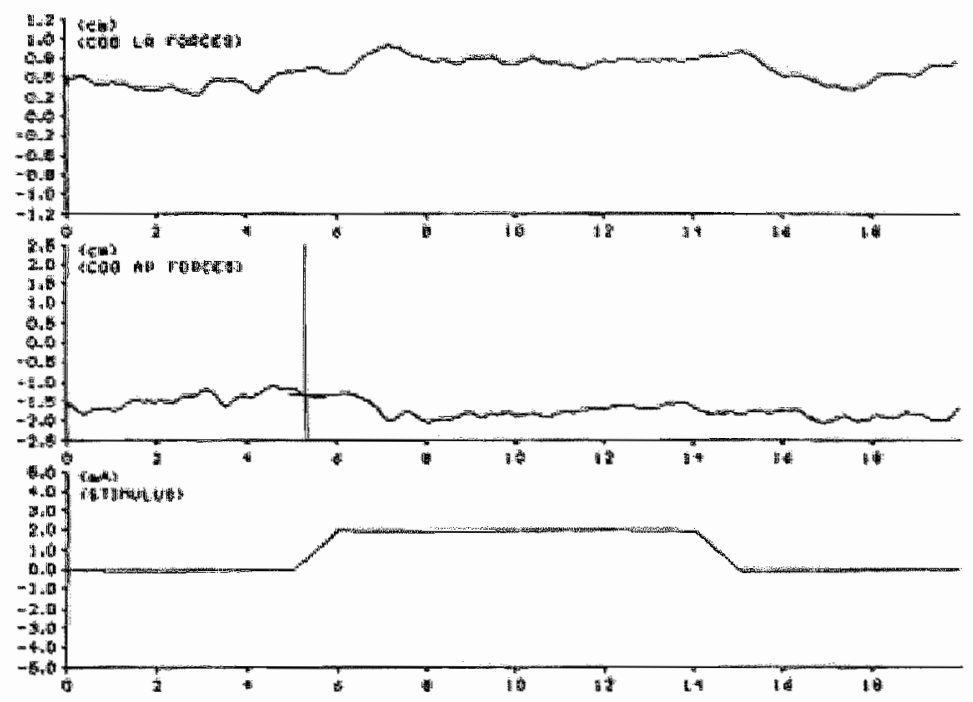

Figure 8: Response trapezoidal stimulation

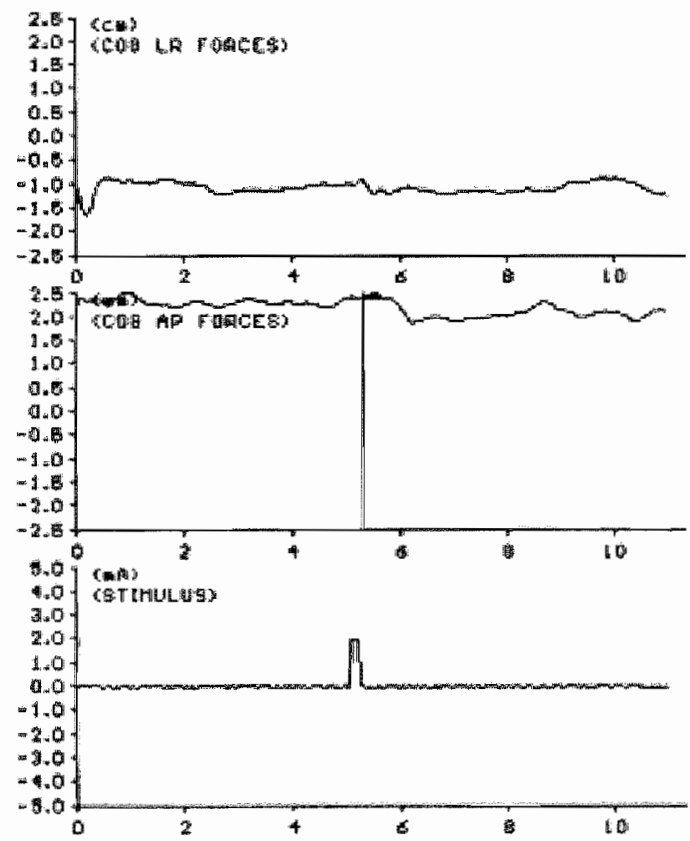

Fìgure 9: Response short pulse stimullation 


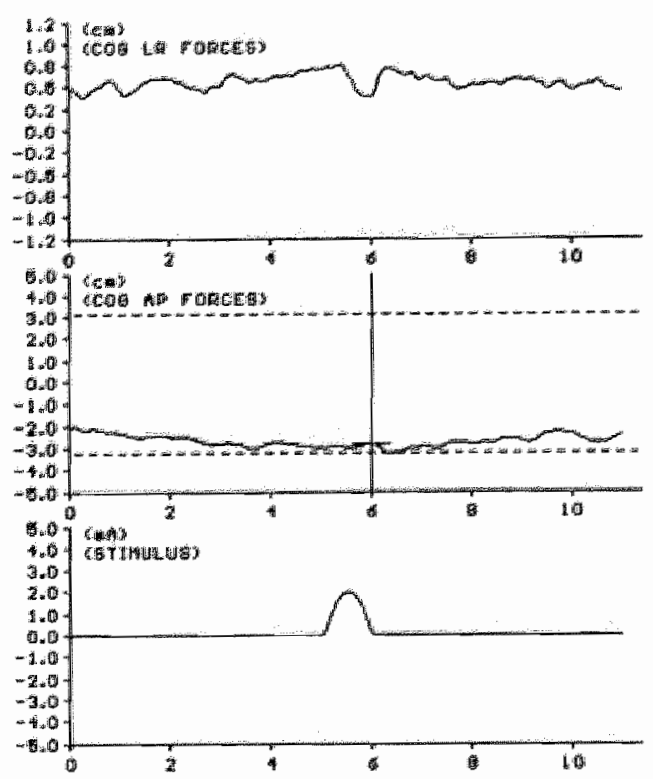

Figure 10: Response 1-cosinusoidal stimulation

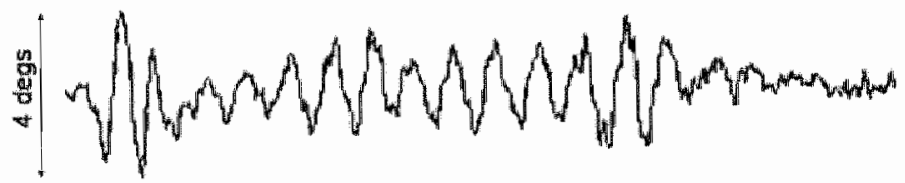

$\begin{array}{lllllllllll}0 & 4 & 4 & 12 & 16 & 20 & 24 & 28 & 32 & 3606\end{array}$

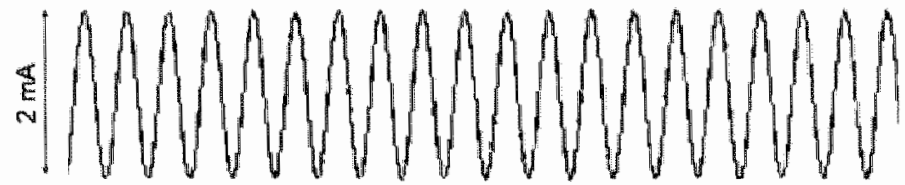

Figure 11: Response continuous 1-cosinusoidal stimulation $(0.5 \mathrm{~Hz} ; 2 \mathrm{~mA})$ 

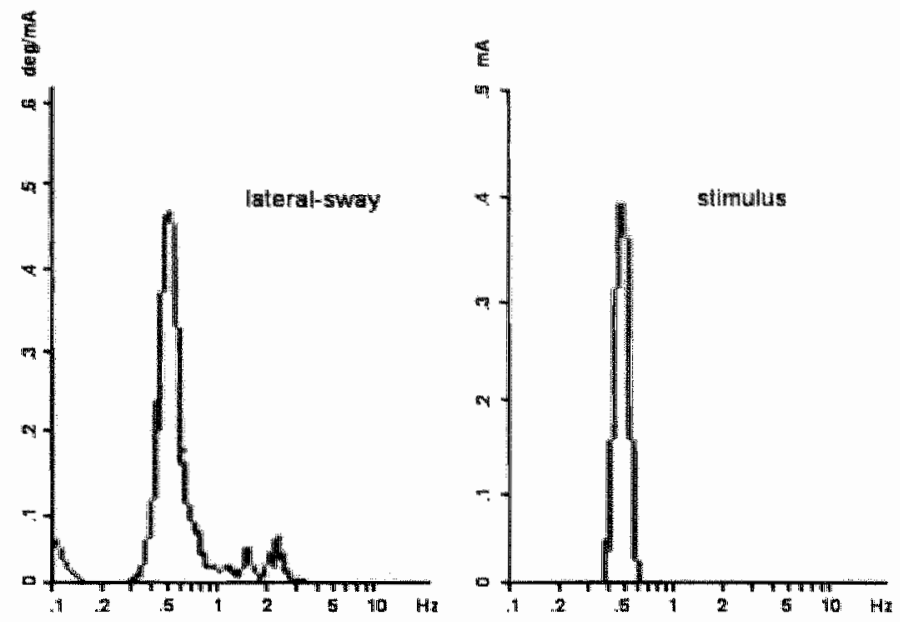

Figure 12: Response continuous 1-cosinusoidal stimulation $(0.5 \mathrm{~Hz} ; 2 \mathrm{~mA})$ after spectral analysis

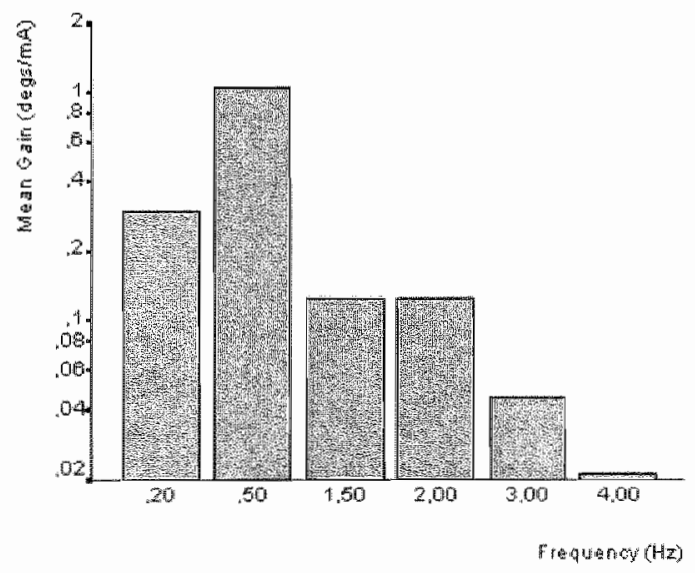

Figure 13: Average GBS as a function of stimulus frequency 
Only the continuous 1-cosinusoidal stimulation (Fig. 11) resulted in reproducible responses. All other stimulus patterns (Figs. 6-10) showed a significant decline in response (habituation) upon repetition that complicated a reliable comparison of dependent parameters.

Habituation was also observed to a lesser extent with continuous1-cosinusoidal stimulation, but this form of stimulation allowed the most reliable measurement of the GBS as a function of stimulus frequency and amplitude. Fig. 13 shows the average GBS $(n=10)$ induced by continuous 1-cosinusoidal stimulation as a function of the stimulus frequency. GBS gain is defimed as the power response of the spectral analysis at the stimulus frequency (FFT), GBS gain at a stimulus frequency of $0.5 \mathrm{~Hz}$ showing optimal responses. Fig. 14 shows the average GBS gain $(\mathrm{m}=10)$ induced by $0.5-\mathrm{Hz}$ stimulation as a function of the stimulus amplitude, stimulus amplitude of $2 \mathrm{~mA}$ showing optimal responses.

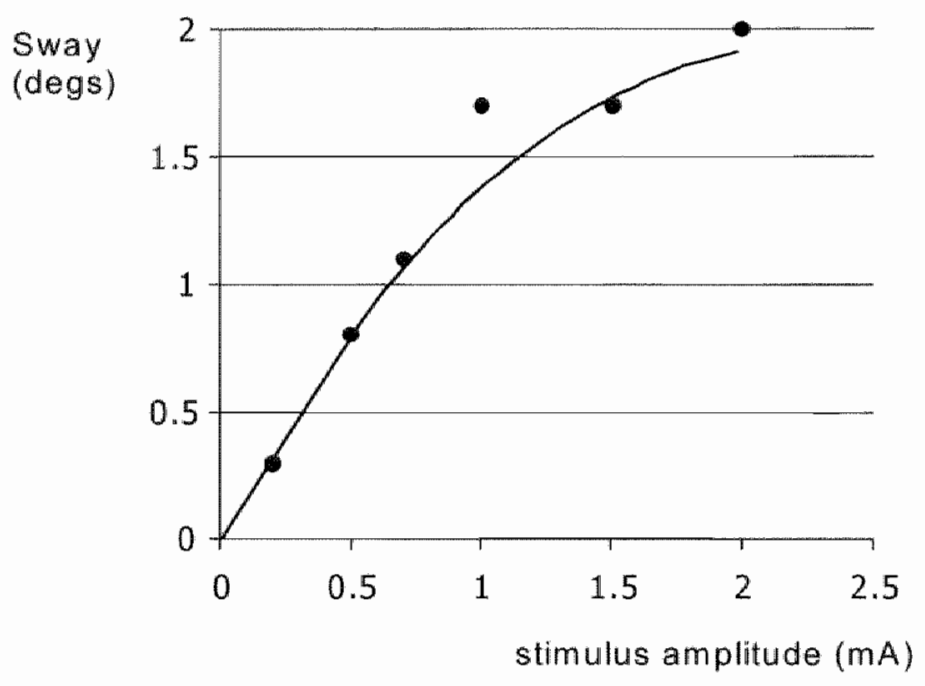

Figure 14: Average GBS as a function of stimulus amplitude

\section{Subjective sensations}

In the normative study, all subjects were asked to report pain or tingling sensations at the electrode positions, abnormal taste sensations, dizziness or a sensation of movement (Fig. 15). Tingling sensations occurred in 60\% of the subjects and abnormal taste sensations ("ifunny taste" or "battery taste") in 18\%. Dizziness was not reported by any of the subjects. Instability or a sensation of body motion was reported by all of the subjects $(100 \%)$.

In previous experiments we observed that subjective sensations tended to increase with stimulus amplitude. One subject reported pain or a slight burning sensation at the side of 
the active electrodes (retro-auricular skin). One subject reported light-headedness and slight nausea.

In the subsequent series of measurements the optimal stimulus of $0.5 \mathrm{~Hz}$ and $2 \mathrm{~mA}$ was applied. As mentioned above, habituation was also observed with this type of stimulation. Fig. 16 shows the decrease in gain during one series of six consecutive measurements (left side, right side, left side, right side, etc). To minimize habituation a binaural sinusoidal stimulation of $0.5 \mathrm{~Hz}$ and $1 \mathrm{~mA}$ was applied pror to the six monaural stimulations. Comparison of Fig. $16 \mathrm{~A}$ and $\mathrm{Fig} .16 \mathrm{~B}$ indicates that prestimulation effectively reduces the habituation phenomenon that might mimic an asymmetric sensitivity (left versus right).

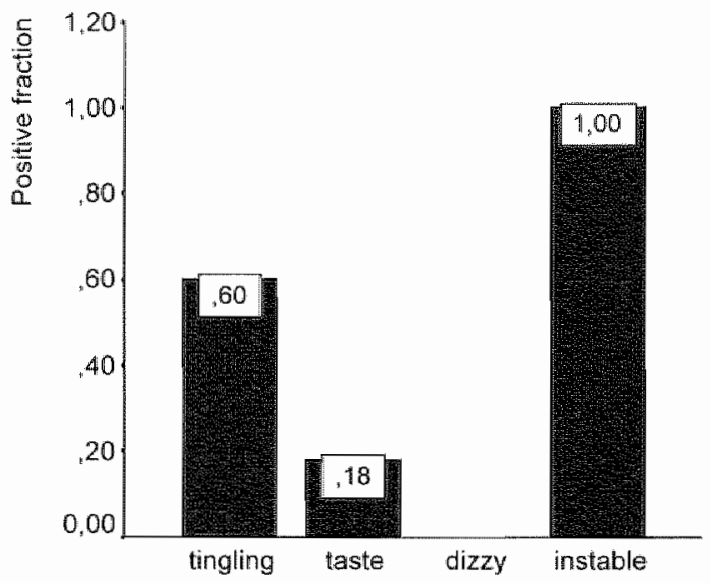

Figure 15: Subjective sensations

Impact of age, physical condition, weight, length, quetelet index, foot size and gender on GBS

No significant relation was found between gain and either age, physical condition, weight, length, quetelet index [weight $\left.(\mathrm{kg}) /(\text { length }(\mathrm{m}))^{2}\right]$, foot size or gender (ANOVA and Pearson's correlation coefficients).

Inter-and intra-subject variability

Inter- was larger than intra-subject variability (Fig. 17). The test-retest variability (intrasubject variability) was $<20 \%$. The correlation between two subsequent tests was high $(p=0.92)$. 


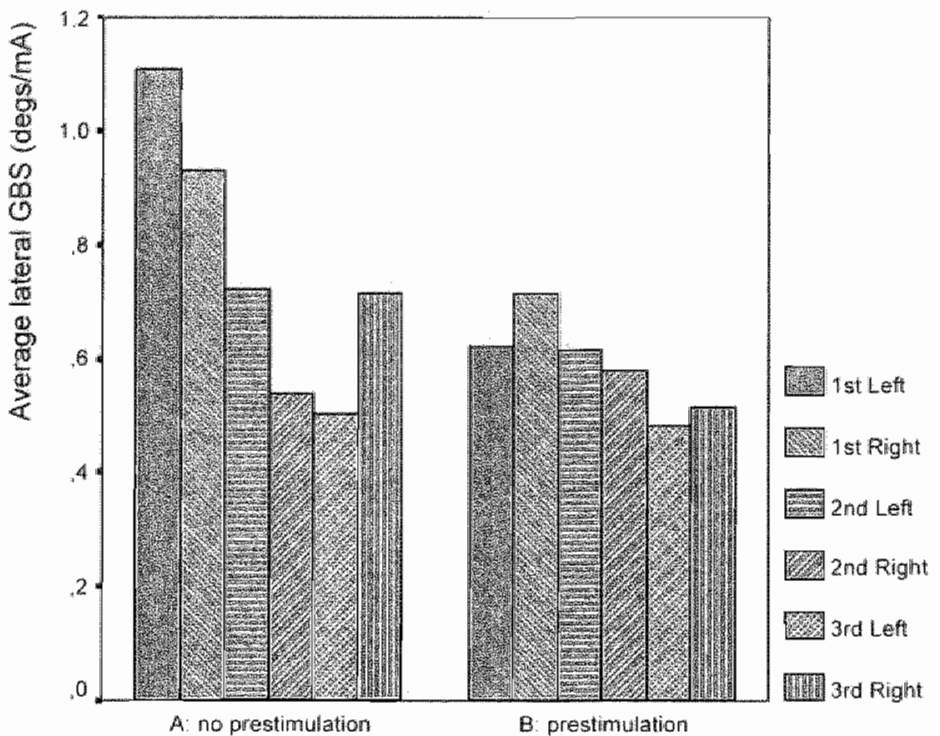

Figure 16: Average GBS with or without prestimulation

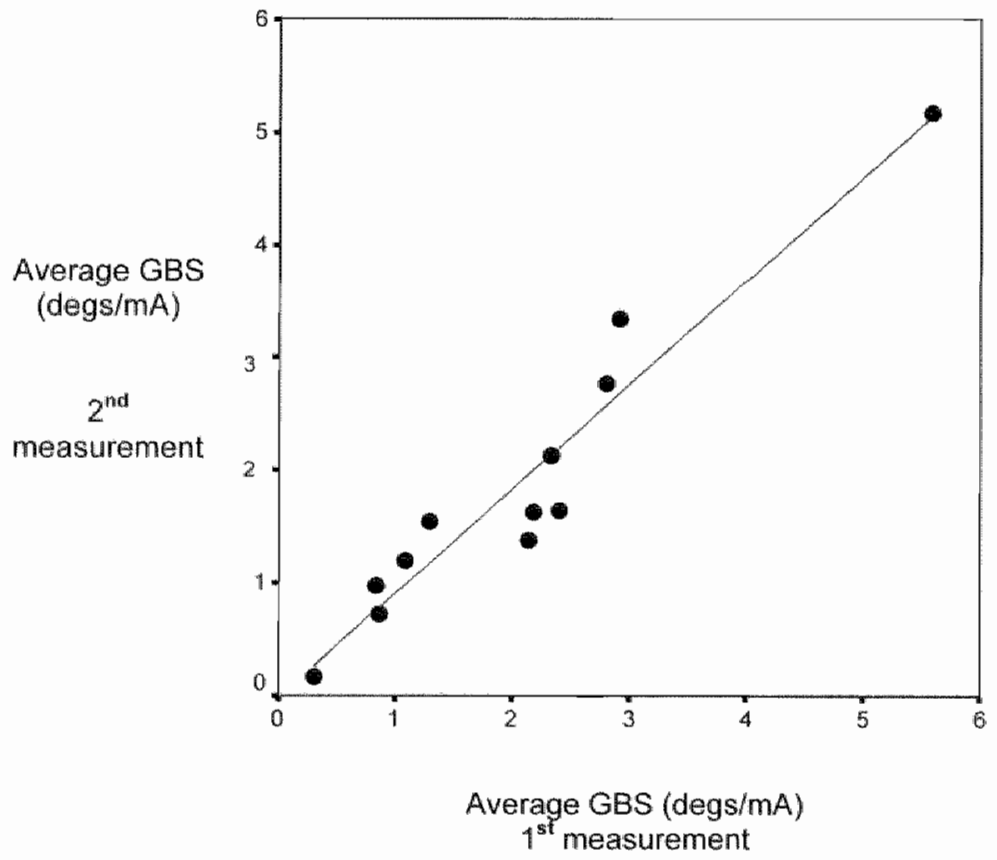

Figure 17: Test-retest variability and intra-subject variability 


\section{DISCUSSION}

GBS or subjective sensation occurred exclusively when the electrodes were placed in the vicinity of the labyrinths, which points to a specific vestibular activation. Only continuous1-cosinusoidal GVS resulted in reproducible responses. The test-retest variability (intra-subject variability) was $<20 \%$. Inter-subject variability was larger, with GBS ranging from $0.3-5.6 \% \mathrm{~mA}$ (Mean 2.1\% $\mathrm{mA}$; SD $1.4 \% \mathrm{~mA}$; SE $0.4 \% \mathrm{~mA}$ ). Spectral analysis showed that maximum responses occurred at $0.5 \mathrm{~Hz}$. Responses increased with stimulus amplitude and saturated at about $2 \mathrm{~mA}$. A detailed study of the amplitude and frequency characteristics will be published in the subsequent chapter. Responses declined upon repetition, indicating substantial habituation. The observed habituation hindered a reliable comparison of side differences in the case of monaural stimulation. Binaural sinusoidal prestimulation reduced this habituation phenomenon substantially, allowing a solid quantification of side differences. Habituation to the sinusoidal stimulus also occurred when non-sinusoidal prestimulation was performed. To our knowledge, habituation to GVS has not been explored extensively or explained in the literature. At random (sham) stimulation might limit habituation. Magnusson et al. (24) used this type of stimulation and analyzed the sway variance as the measure of outcome. In another study, Magnusson's group showed that the sway variance does not vary with the stimulus frequency, in contrast to our observations when periodic stimuli are applied. As we were specifically interested in the frequency dependence of the transfer function, we choose an evaluation of periodic stimuli. These allow easy frequency analysis, are applied most frequently in literature (especially in the clinic) and allow a comparison with other studies.

In a previous Dutch report we hypothesized that the habituation might show the ability of the vestibular system to recognize and partially neglect a non-physiological input. A recent paper by Cenciarini et al. supports this hypothesis, indicating that the galvanic habituation is a centrally mediated phenomenon associated with the sensory reweighting process (25). The results of an extensive study related to this habituation process will be discussed in a following chapter. Interestingly, we observed, in line with other reports, that habituation occurred to all the stimulus profiles that we studied. Habituation to the sinusoidal stimulus also occurred when non-sinusoidal prestimulation was performed. So habituation is indeed a common finding. The choice of sinusoidal stimulation is, however, primarily based on the relatively good reproducibility and large GBS amplitude and not as much on the habituation aspect.

The subjective sensations (tingling, taste "dizziness, instability) indicate that, in addition to the vestibular system, other sensory systems, e.g. the visual, are also stimulated. This suggests that the stimulus induces an electrical field that expands over a wide area. Remarkably, no auditory sensations are induced. We can only speculate about an explanation for this phenomenon, but perhaps the auditory system is insensitive to the low frequencies applied. No significant relation was found between the GBS gain and either age, physical condition, weight, length, quetelet index, foot size or gender. However, our study population was too small for possible weak correlations to be shown. Further analysis will be necessary at lower stimulus intensities where no saturation occurs. In 
surmmary, we are convinced that the current approach brings the implementation of the GVS as a clinical test close to reality. 


\section{REFERENCES}

1. Cass S, Redfern M, Furman J, DiPascquale J. Galvanic-induced postural movements as a lest of vestibular function in humans. Laryngoscope 1996;106;423-430.

2. Watanabe $Y$, Mizukoshi $K$, Otyi $H$, Yasuda $K$, Ohasi $N$. Kobayashi $H$. Retro-labyrinthine disorders detected by galvanic body sway response in routine equilibrim examinations. Acta Oto-Lanyngol. Suppl. 1989; 468: :343-348.

3. Lund $S$, Broberg $C$. Effects of different head positions on postural sway in man induced by a reproducible vestibular error signal. Acta Physiol. Scand. 1983:417:307-309.

4. Britton T, Day B, Brown P, Rothwell J, Thompson P. Marsden C. Postural electro-myographic responses in the arm and leg following galvanic vestibular stimulation in man. Exp. Brain Res. 1993;94:143-151.

5. Coats A. Effect of varying stimulus parameters on the galvanic body-sway response. Ann. Otol. $1973 ; 82: 96-102$.

6. Coats A. Limit of normal of the galvanic body-sway test. Ann. Otol. 1972;81:410-416.

7. Sekitani T. Differential diagnosis of vertigo - combined galvanic test and MRI. Acta OtoLaryngol. Suppl. 1988:458:113-119.

8. Courjon J, Precht $W_{\mathrm{n}}$ Sirkin D. Vestibular nerve and nuclei responses and eye movement responses to repetitive galvanic stimulation of the labyrinth in the rat. Exp. Brain Res. $1987 ; 66: 41-48$.

9. Day $B$. Séverac Cauquil $A$, Bartolomei $L$, Pastor M, Lyon I. Human body-segment tilts induced by galvanic stimulation: a vestibularly driven balance protection mechanism. J. Physioll. 1997;500:661-672.

10. Johansson $R$, Magnusson $M$, Fransson P. Galvanic vestibular stimulation for analysis of postural adaptation and stability. IEEE Trans. Biomed. Eng. 1995;42:282-292.

11. Day $B$, Pastor $M$, Bartolomei $L$, Bonato $C$. Influence of conflicting sensory information on vestibular-induced postural adjustments in man. Jpn. J. Physiol. 1995;45, Suppl. 2:S333.

12. Coats A. The sinusoidal galvanic body-sway response. Acta Oto-Laryngol. Suppl. 1972;74:155162.

13. Lowenstein OJ. The effect of galvanic polarization on the impulse discharge from sense endings in the isolated labyrinth of the thomback ray (raja clavata). Physial. 1955;127:104-117.

14. Goldberg J. Fernandez $\mathrm{C}$. Smith $C$. Responses of vestibularmerve afferents in the squirrel monkey to externally applied galwanic currents. Brain Res. 1982;252:156-160.

15. Goldberg J, Smith $C$. Fernandez $C$. Relation between discharge regularity and responses to externally applied galvanic currents in vestibular nerve afferents of the squirrel monkey. d. Neurophysiol. 1984,51:1236-1256.

16. Nashner L. Wolfson P. Influence of head position and proprioceptive cues on short latency postural reflexes evoked by gallvanic stimulation of the human labyrinth. Brain Res. $1974,67: 255-268$.

17. Pastor M. Day $B$, Marsden $C$. Vestibular induced postural responses in Parkinson's disease. Brain 1993;116:1177-1190. 
18. Fransson $P$, Karlberg M. Sterner $T$. Magnusson M. Direction of galvanically-induced Vestibulopostural Responses during active and passiwe neck torsion. Acta Oto-Laryngol. Suppl. $2000: 120: 500-503$.

19. Coats A. The variability of the galvanic body-sway test. Anm. Otol. 1973;82:333-339.

20. Ahn SC, Lee CY, Kim DW, Lee MH. Short-term vestibular responses to repeated rotations. J. Vest. Res. 2000;10(1):17-23.

21. Barries $G$. Adaptation in the oculomotor response to caloric irrigation and the merits of bithermal stimulation. Br. J. Audiol. 1995;29(2):95-106.

22. Albert HHv. Untersuchungen zur habituation des postrotatorischen nystagmus. Dtsch. $Z$. Nerverheilk. 1965:187.503-506.

23. Winter DA. Biomechanics of human movement. New York: Wiley \&Sons; 1979.

24. Magnusson $M$, Johansson $R$, Wiklund J. Galvanically induced body sway in the anteriorposterior plane. Acta Otolaryngol. (Stockh) 1990;110:11-17.

25. Cenciarini $M$. Peterka $R_{*}$, Horak $F$. Habituation to galvanic vestibular stimulation depends on sensory reweighting. J. Vest. Res, 2001/2002;11(3-5):288. 


\section{Chapter 3}

\section{Frequency dependence of galvanic-induced body sway}

Herman Kingma, Susanne G.T. Balter, Cindy Penners Accepted for publication in Acta Otolaryngol 


\section{ABSTRACT}

Objective - Quantification and verification of the frequency dependence of galvanicinduced body sway (GBS).

Materials and Methods - This was a prospective experimental study conducted in a lertiarry referral center. The study was performed in 12 healthy subjects that underwent binaural continuous 1-cosinusoidal galvanic vestibular stimulation (GVS) with eyes closed. Movements of the center of pressure were measured using a force platform. Lateral GBS was analyzed when the head was facing forwards, sagittal GBS was analyzed when the head relative to the feet was rotated over 90 degrees to the left. Both the log transformed torque variance (LTTV) of GBS and the GBS gain were calculated to determine the frequency dependence of the responses.

Results - The LTTV of the lateral and sagittal GBS did not depend on the stimulus frequency. In contrast, lateral and sagittal GBS gain showed a clear optimum between 0.20 and $0.29 \mathrm{~Hz}$ and decreases with increasing frequency down to nil.

Conclusion - We could confirm the results presented by Peterson et al (1) that LTV is invariant to the stimulus frequency. However, in contrast to the LTTV, the GBS gain showed a clear dependence on the stimulus frequency in agreement with the galvanicinduced ocular torsion (2). The discrepancy can be explained by the fact that, in case of the calculation of the LTTV, the response per frequency is composed of contributions of all frequencies in the response proflle, which masks a possible frequency-dependence. In case of calculation of the power response per frequency, the response is composed by contribution of response at the associated stimulus frequency onlly. Our results indicate that, in case of a clinical application of GBS, the frequency dependence of GBS has to be takem into account.

Key words: galvanic vestibular stimulation, frequency dependence, torque variance, healthy subjects

\section{INTRODUCTION}

Galvanic stimulation of the vestibular system (GVS) is a challenging technique for application in the clinic, because of the ability to stimulate the left and right vestibular system separately, the involvement of both vestibulo-ocular and vestibulo-spinal reflexes and the suggestions in the literature that it might allow discrimination between labyrinthine and retro-labyrinthine disorders $(2-9)$. However, no standardized procedures have been introduced that are generally accepted so far. To standardize the technique, both amplitude and frequency characteristics need to be well documented. The frequency dependence of galvanic-induced ocular torsion has been described by Schneider et all. (2). They observed low pass frequency characteristics with a maximum gain of on average 1 $\operatorname{deg} / \mathrm{mA}$ at $0.01 \mathrm{~Hz}$ that decreases substantially at stimulus frequencies above $0.1 \mathrm{~Hz}$ till nil at about $1 \mathrm{~Hz}$. 
To our knowledge, the frequency dependence of gavanic-induced body sway (GBS) was first and only reported and analyzed by Petersen el al. (1). With a force platform they measured body sway induced in normal subjects by binaural galvanic stimulation at stimulus frequencies ranging from 0.2 to $4.0 \mathrm{~Hz}$ with amplitudes of $\pm 1 \mathrm{~mA}$. Petersen et al. reported that the log transformed torque variance (LTTV) of body sway velocity did not vary with stimulus frequency. In contrast, during the clinical application of GVS (10, 11). we got the impression that the GBS gain that is calculated from the power spectra of the response and stimulus, does depend on the stimulus frequency. We therefore repeated the experiments of Peterson et al. in 12 healthy subjects. Apart from determining the frequency dependence of the LTTV, we also analyzed the power spectra of body sway to obtain an extended insight in the frequency characteristics of GBS.

\section{MATERIALS AND METHODS}

\section{Subjects}

Twelve healthy subjects were tested ( 6 males, 6 females; mean age 37 years; range 23 56 years). Subjects with a history of better-than-average motor or ballance skills (ballet dancers, gymnasts, and semi-professional sportsmen) and those with a history of vestibular, musculoskeletal or neurological complaints were excluded. Subjects did not use any medication that could affect the vestibular or musculoskeletal system. Alcohol consumption was prohibited for $24 \mathrm{~h}$ prior to testing.

\section{Materials}

A computer-controlled stimulator, built in our department and meeting the appropriate safety regulations (IEC 601.1), generated the galvanic stimulus described below. The stimulator is equipped with a feedback mechanism so that an identical galvanic stimulus can be applied to every subject tested, irrespective of the electrical conductivity of skin and temporal bone. The electrodes measure $50 \times 35 \mathrm{~mm}^{2}$ and are composed of silicon rubber, mixed with conducting carbon particles (CEFARTM Medical Products, Lund, Sweden). The electrodes were attached to the retro-auricular skin with electroconductive adhesive gel (Tac Gelim). Movements of the centre of pressure (COP) were measured using a force platform $\left(42 \times 35 \mathrm{~cm}^{2}\right.$; Jaeger-Toennies $\mathrm{GmbH}$. Wurzburg, Germany) equipped with four transducers, one at each corner. Data-acquisition (50 $-\mathrm{Hz}$ sampling rate) and analysis were performed using a T-Post-Nystagliner computer system (JaegerToennies $\mathrm{GmbH}$ ). 
Prior to testing the retro-auricular skin was cleaned with petroleum ether and Tac Gelp* was applied to three electrodes. The gel was allowed to dry for five min to improve adhesion to the skin. We placed two electrodes at the mastoid, one behind each ear. A third electrode was placed on the neck at the $C 7$ vertebra (10). The electrodes were fixed with adhesive tape (Mefix@). Subjects wore headphones in order to optimize retro-auricular stabilization of the electrodes and reduce auditory spatial orientation. During each test. lights in the test cabin were dimmed and the subjects were ordered to keep their eyes. closed to prevent any visual orientation. Subjects were instructed to stand upright in bare closed feel (inter-foot distance $0 \mathrm{~cm}$ ) on the force platform with their arms crossed in front of their body. The test cabin was prowided with a frame surrounding, which did not touch the subject, in order to prevent a fall in the case of severe imbalance.

To avoid strong habituation effects (11) all subjects received a prestimulus consisting of a 40 -s continuous binaural sinuscidal $0.5-H z$ stimulation of $\pm 1 \mathrm{~mA}$. To measure GBS frequency dependence in both the lateral and sagittal plane, we subsequently performed two measurements series. First series: the subject faced forward (lateral movement). Second series: head and shoulders turned over to the left in such a way that the head was rotated about 90 degrees relatively to the feet (sagittal movement). First, the natural body sway (NBS) of each subject was measured in both series, without any stimulation for $40 \mathrm{~s}$ (zero-measurement). To avoid saturation effects (10) and to allow an optimal comparison of our results with those of Peterson et al. a maximum amplitude of $\pm 1 \mathrm{~mA}$ was applied for all subsequent measurements. To avoid interference between habituation and frequency dependence, the test sequence of stimulus frequencies was randomized over the 12 subjects.

\section{Data analysis}

In all subjects we observed that at stimulus frequencies above $1.5 \mathrm{~Hz}$, a significant peak appeared in the power spectrum between 0.2 to $0.3 \mathrm{~Hz}$ (see results). At the end of every series of measurements we additionally stimulated all subjects at this so called "resonance frequency" and detected the LTTV and the frequency spectra. LTTV was calculated as described by Peterson et al.

The power spectra were based on calculation of the GBS expressed in degrees per $m A$. First, the displacement of the COP was normalized for body length:

$$
\text { Body sway }\left({ }^{\circ}\right)=\operatorname{cotan}[\mathrm{COP} /(0.56 \times \text { body length })]
$$

Here we assume that the centre of body mass is positioned on average at a point $56 \%$ along the length of the body (12). The frequency spectrum of the time series is calculated by fast Fourier transform (FFT) using a Hamming filter and a 2048-point window. The frequency spectrum acquired with stimulation is then corrected for the background noise and the NBS by subtracting the frequency spectrum acquired without stimulation. Subsequently, the average amplitude of the difference spectrum is calculated at the 
stimulus frequency ( 7 classes wide of the discrete Fourier spectrum), taken as the typical response and normalized relative to the stimulus amplitude (in millamperes). The response is expressed in degrees per milliampere.

Similar to the GBS gains and the procedure described by Peterson et al., all LTTV spectra were corrected for the natural sway obtained without galvanic stimulation (zero measurement).

Statistical analysis (Mann-Whitney U-test, Independent Samples Test, KolmogorovSmirnov Test for Normality, Pearson and Spearman correlation tests) was performed using SPSS software (version 11.0; SPSS Inc., Cary, NC).

\section{RESULTS}

\section{Log transformed torque variance (LTTV)}

Fig. 1 shows the results obtained in the twelve healthy subjects using the LTTV as the outcome parameter in comparison to the original data of Peterson et al. Responses did not significantly differ between the various stimulus frequencies $(p>0.05)$ and between the lateral and sagittal LTTV. The LTTV for lateral and sagittal GBS ranged from 1.45 to 2.18 ( $S D<0,48)$, which is slightly less than reported by Petersen et al.
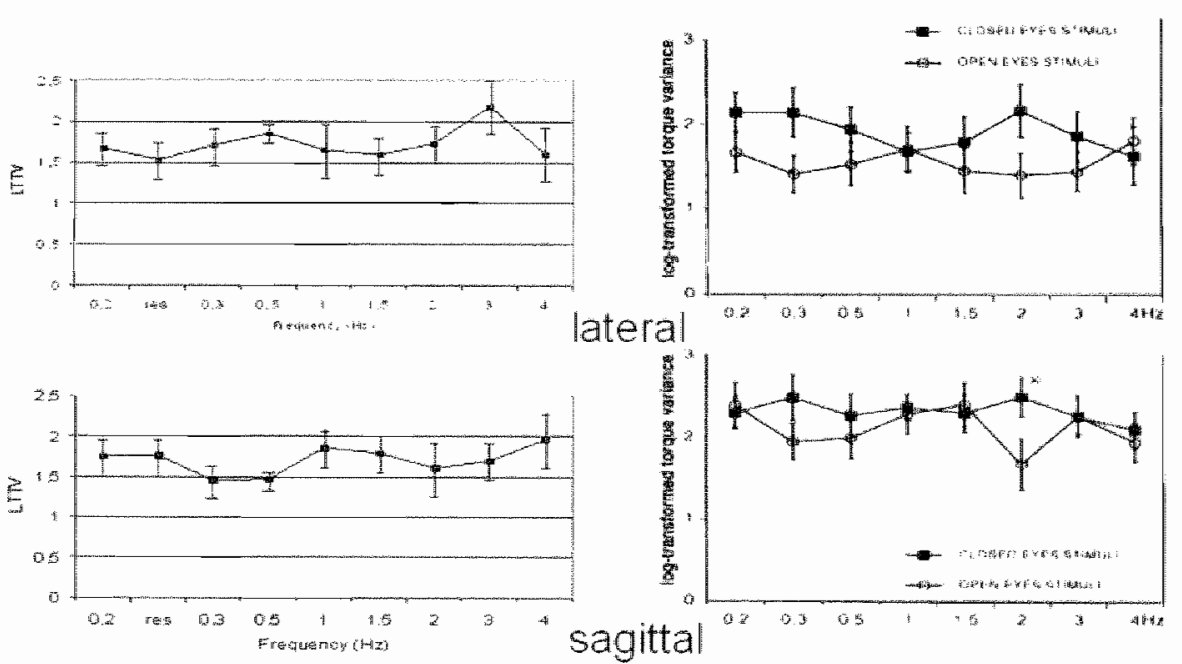

Figure 1: LTTV as a function of stimulus frequency Left graphs: results of this study Right graphs: results copied from Peterson et al. 
Fig. 2 shows the GBS gains calculated from the power spectra of stimulus and respionse. Responses clearly depend on the stimulus frequency. GBS gains were maximum between 0.2 and $0.29 \mathrm{~Hz}$. At low frequencies $(<1 \mathrm{~Hz}$ ) the subjects swayed with a frequency equal to the stimulus. At high frequencies $(>3 \mathrm{~Hz})$ the inertia of the body prevented the subjects from swaying at the stimulus frequency. In that case, the energy put in the system resulted in a GBS at a lower frequency, which we suggest to be the "resonance frequency". Stimulation above $1.0 \mathrm{~Hz}$ resulted in this additional peak in the power spectrum of the response situated between 0.20 and $0.29 \mathrm{~Hz}$ (Fig. 2: arrow Res). The average "resonance frequency" was $0.23 \mathrm{~Hz}(S D 0.03 \mathrm{~Hz})$ for the lateral GBS gain, which was not significantly different $(\rho>0.05)$ from the average "resonance frequency" of the sagittal GBS gain (0.24 Hz, SD 0.04).

The "resonance frequiencies" were not correlated to body weight or body length (rho< $0.2, p>0.05)$.

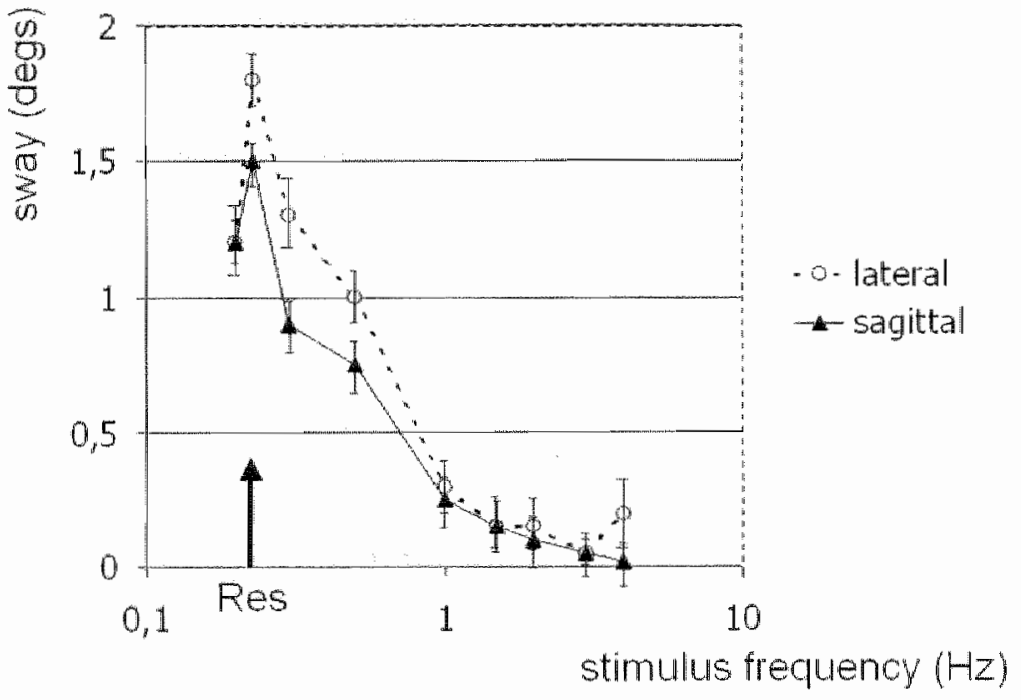

Figure 2: GBS as a function of the stimulus frequency as obtained by calculation of the power spectra 


\section{DISCUSSION}

We observe that the GBS gain depends on the stimulus frequency. GBS gain is maximum between 0.2 and $0.3 \mathrm{~Hz}$ and decreases with frequency up to $4 \mathrm{~Hz}$. The system behaves to some extent non-linear: stimulation at any frequency results in minor but evident responses between 0.2 and $0.3 \mathrm{~Hz}$, designated as a possible "resonance frequency" related to the body dynamics. This would imply that calculating the transfer functions, implicit assuming a linear system, is not a valid approach per se. However, the contribution of the response at the "resonance frequency" to the total response is only small, which validates a linear system analysis as a first approach. Schneider et al. described a low pass frequency characteristic of the galvanic-induced ocular torsion and suggest that the response is dominated by semicircular canal input. As posture control is predominantly influenced by statolith input, our data indicate that the galvanic stimulus (also) excites the statolith input. Apart from the "resonance frequency", we also observe a low pass characteristic. The similarity suggests that the frequency dependence is dominated by the characteristics of the excitation process and not that much by the frequency characteristics of the semicircular canals or statolith organs or mechanics of the eye or body. However, the absence of a "resonance frequency" in the galvanicinduced ocular torsion spectra suggests that the "resonance frequency" may be induced by the mechanics of the body.

To summarize, the hypothesis seems just that low pass frequency characteristics of lateral and sagittal GBS and ocular torsion are determined by the sensitivity of the receptors (probably retro-labyrinthine) to the galvanic stimulus. The mechanicall characteristics of the body are responsible for the GBS peak between 0.2 and $0.3 \mathrm{~Hz}$. Counteracting this last statement is the fact that the "resonance frequency" is not related to body length or weight. Maybe the remaining variability and the relatively small population are the cause of a missing significant correlation. The absence of a "resonance frequency" in the galvanic-induced ocular torsion spectra suggests that the "resonance frequency" may be induced by the mechanics of the body. However, the "resonance frequency" is the same for lateral and sagittal GBS, and is not related to body length or weight, which suggests that the frequency dependence of the GBS is perhaps more determined by the frequency sensitivity of vestibulo-spinal systern than by body dynamics.

In agreement with Peterson et al., we found that the LITV does not vary with stimulus frequency. Apparently, the analysis technique is crucial in relation to the frequency characteristics of the response. The seemingly discrepancy can be explained as follows. Although both Peterson et al. and we corrected the data for the NBS, still when using the LTTV as a response measure, all frequency components of the response contribute to the outcome, irrespective the stimulus frequency. This results in a masking of the frequency dependence that is not present when a common spectral analysis (FFT) is performed. Taken this into account and considering the spectra presented here, we conclude that GBS does depend on the stimulus frequency.

Our results indicate that in case of a clinical application of GBS, the frequency dependence of GBS has to be taken into account. We are currently exploring the fundamental 
arigin of the frequency dependence of GBS that we obsened and especially that of the "resonance frequency". For our further explorative clinical studies, we choose a stimulus frequency of $0.5 \mathrm{~Hz}$ at which substantial responses occur(10). We avoided the "resonance frequency" as a stimulus frequency, because the precise origin is still unclear. 


\section{REFERENCES}

1. Petersen $H$, Magnusson M. Fransson PA. Johansson R. Vestibular stimulation perturbs human stance also at higher frequencies. Acta Otolaryngol Suppl 1995,520 Pt 2:443-6.

2. Schneider $E$, Glasauer $S$. Dieterich M. Central processing of human ocular torsion analyzed by galvanic vestibular stimulation. Neuroreport 2000;11(7):1559-63.

3. Pfaltz CR. [The galvanic vestibular test]. Acta Otorhinolaryngol Belg 1965;19(2);367-73.

4. Pfaltz CR. [Proceedings: Studies on the diagnostic significance of the galvanic test in acoustic neurinoma]. Arch Klin Exp Ohren Nasen Kehlkopfheilkd 1973;205(2): 130-4.

5. Pfaltz CR, Rilchter HR. [The diagnostic value of the galvanic vestibular reaction]. Confin Neurol $1965 ; 25(4): 203-9$

6. Pfaltz $C R$, Koike $Y$. Galvanic test in central vestibular lesions. Acta Otolaryngol 1968;65(1):1618.

7. Pfallz CR. The diagnostic importance of the galvanic test in otoneurology. Pract Otorhinolaryngal (Basell) 1969:31(4):193-203.

8. Gosepath K, Maurer J. Mann W. Diagnostik intrameatal gelegener akustikusneurinome-die rolie akustisch evozierter hirnstampotentiale und anderer otoneurologischer untersuchungsverfahren. Laryngo-Rhino-Otol. 1995;74:728-732.

9. Hulshof $\mathrm{JH}_{\text {" Hilders }} \mathrm{CG}$, Baarsma EA. Vestibular investigations in acoustic neuroma. Acta Otalaryngol 1989;108(1-2):38-44.

10. Balter SG, Stokroos RJ, Boumans $R$, Kingma $H$. Background on methods af stimulation in galvanic-induced body sway in young healthy adults. Acta Otalaryngol 2004;124(3):262-71.

11. Balter SG, Stokroos RJ, Eterman RM, Paredis SA Orbons J Kingma H. Habituation to glalvanic vestibular stimulation. Accepted for publication in Acta Otolaryngol.

12. Winter DA. Biomechanics of human movement. New York: Wiley \&Sons: 1979. 



\section{Chapter 4}

\section{Habituation to galvanic vestibular stimulation}

Susanne G.T. Balter, Robert J. Stokroos, Rosemiek M.A. Eterman, Sophie A.B. Paredis, Joep Orbons, Herman Kingma

Accepted for publication in Acta Otolaryngol 


\section{ABSTRACT}

Objective - To examine the response decline that occurs upon repetitive galvanic vestibular stimulation (GVS) and hampers long-term clinical evaluations.

Materials and Methods - This was a prospective experimental study conducted in a teriary referral centre. In our previous study we developed a standardized procedure for reproducible quantification of galvanic-induced body sway (GBS). The most reproducible responses were found using a continuous 1-cosinusoidal stimulus $(0.5 \mathrm{~Hz} ; 2 \mathrm{~mA})$ preceded by a pre habituating stimulus. This binaural prestimulation reduced the shortterm ( $<5$ min) response decline to a non significant level. The response decline without prestimulation was interpreted as habituation to the galvanic stimulation. In the present study we evaluated possible long-term habituation to GVS, which may hamper longitudinall clinical evaluations. Possible long-term habituation using the short-term habituating prestimulus concept was studied by quantifying GBS in 40 subjects at 5 consecutive time points. Subjects were subdivided into four groups who were tested with four different time-intervals between the five measurements, ranging from 1 day to 2 weeks.

Results - The absolute test results did not vary with the time interval $(p=0.217$; repeated measurement test). Irrespective the time interval between the tests, habituation occurred after the first stimulation and remained stable at all consecutive measurements. GVS habituation did not depend on the either the degree of daily life activity (moderate practice of sports) or on gender.

Conclusion - The current protocol, using a prehabituating binaural stimulus, showed that a reproducible assessment of the GVS over a time course of days to weeks was possible starting from the second test.

Key words: daily life acilvity, galvanic vestibular stimulation, habituation, response decline

\section{INTRODUCTION}

Vestibular afferent neurons exhibit a resting discharge (100 spikes/s), even in the absence of any stimulus (1). The spontaneous activity is either increased or decreased upon stimulation. A great variety of stimulation techniques can be used in order to excite vestibular receptors. It is generally accepted that angular as well as linear accelerations are the physiological or adequate stimuli for vestibular receptors. However, it is thought that the receptors are bypassed in galvanic vestibular stimulation (GVS), or when anodal and cathodal polarizing currents are applied to the mastoids (2). In the primary and most of the siecondary vestibular neurons, cathodal stimulation generally increases the discharge frequencies and anodal stimulation has the opposite effect. Often response declines upon prolonged or repeated stimulation, which is designated as either adaptation or habituation to the stimulus. There is considerable confusion surrounding the difference between adaptation and habituation. For clarity we use the following definitions. Adapta- 
tion refers to the response decline during constant stimulation. Generally, sensory receptors adapt to constant stimulation. The receptor potential then invariably decreases in amplitude in response to a sustained stimulus (3). Receptor adaptation is thought to be an important component of perceptual adaptation (1 4). Habituation is the simplest way in which an organism learns about the properties of a novel stimulus when that stimulus is repeated. The learned suppression of the response to a repeated stimulus is called habituation (1). Habituation requires feedback to inform the organism that the stimulus is less relevant. Habituation to vestibular stimulation is a well-known phenomenon which is observed for example in repeated velocity step experiments (5) and repeated caloric irrigation $(6,7)$, whereas adaptation occurs during prolonged caloric irrigation $(6,7)$. Many years ago, Lowenstein (8) found that the discharge rate of primary neurons connected to the semicircular canals showed only very slight adaptation in a isolated preparation of the labyrinth of the thomback ray. However, in the intact frog $65 \%$ of the primary fibres showed signs of adaptation in response to prolonged acceleration steps (9). This may imply that in the intact preparation the efferent vestibular system may contribute to the frequency decline in response to constant acceleration. Also, even if there is a slight tendency for adaptation in some neurons, it is not significant enough to explain the considerable "adaptation" observed by Hallpike and Hood (10) in human subjects under the condition of sustained cupula deflection. Single neuron studies would suggest that the response decline is not only produced by intherent mechanisms in the end organs or in the vestibular nuclei but may also involve more complicated neuronal reflex pathways situated downstream from the vestibular nuclei (11). The aim of this study was to examine the response decline in GVS, as reported previously (2). We focused on the onset, duration and offset of the habituation process.

\section{MATERIALS AND METHODS}

\section{Subjects}

Forty healthy subjects were tested (20 males, 20 females, mean age 25.6 years, range 20-45 years). Subjects with a history of vestibular, musculoskeletal or neurological complaints were excluded. Subjects were not using any medication that could affect the vestibular or musculoskeletal system. Alcohol consumption was prohibited for $24 \mathrm{~h}$ prior to testing. The subjects were subdivided into 4 equal groups as foliows: Group 1 were tested every day for a period of 5 days; Group 2 were tested every olher day for a period of 10 days; Group 3 were tested every week for a period of 5 weeks; and Group 4 were tested every other week for a period of 10 weeks.

All consecutive tests were performed at about the same time of day to make the time intervals between the tests as constant as possible. Subjects were also categorized into three subgroups based on their daily life activity (moderate practice of sport) as follows: 
Group 1, no practice of sport; Group 2, practiced sport 1-3 times a week; Group 3, practiced sport $>3$ times a week.

\section{Materials}

A computer-controlled stimulator, built in our department and meeting the appropriate safety regulations (IEC 604.1), generated the galvanic stimulus type described below. The stimulator is provided with a feedback mechanism so that an identical galvanic stimulus can be applied to every subject tested, irrespective of the electrical conductivity of skin and temporal bone. The ellectrodes measure $50 \times 35 \mathrm{~mm}^{2}$ and are composed of silicon rubber, mixed with conducting carbon particles (CEFAR ${ }^{\mathrm{TM}}$ Medical Products, Lund, Sweden). The electrodes were attached to the retro-auricular skin with electroconductive and adhesive gel (Tac Gellm). Movements of the centre of pressure (COP) were measured using a force platform $\left(42 \times 35 \mathrm{~cm}^{2}\right.$; Jaeger-Toennies $\mathrm{GmbH}$, Wurzburg, Germany) equipped with four transducers, one at each corner. Dataacquisition (50 $\mathrm{Hz}$ sampling rate) and analysis were performed using a T-PostNystagliner computer system (Jaeger-Toennies $\mathrm{GmbH}$ ).

\section{Procedure}

Prior to testing, the retro-auricular skin was cleaned with petroleum-ether and Tac Gel't was applied to three electrodes (12). The gel was allowed to dry for five min to improve adhesion to the skin. Two electrodes were placed at the mastoid, one behind each ear. A third electrode was placed on the neck at the $C 7$ vertebra. In the case of monaural stimulation the retro-auricular electrodes were used as positive electrodes and the neck electrode as a negative electrode. The electrodes were fixed with adhesive tape (Mefix(B)). Subjects wore headphones in order to optimize retro-auricular stabilization of the electrodes and reduce auditory spatial orientation. During each test, lights in the test-cabin were dimmed and the subjects were ordered to keep their eyes closed to prevent any visual orientation. Subjects were instructed to stand upright in bare feet with their feet together (inter-foot distance $0 \mathrm{~cm}$ ) on the force platform with the arms crossed in front of the body. The test cabin was provided with a frame surrounding, which did not touch the subject, in order to prevent a fall in the case of severe imbalance. In each test the following eight test sequences were completed: First, the natural body sway (NBS) of each subject was measured without any stimulation for $40 \mathrm{~s}$ (zero reference). Next, all subjects received a prestimulus consisting of a 40 -s continuous binaural sinusoidal $0.5-\mathrm{Hz}$ stimulation of $1 \mathrm{~mA}$. Subsequently all subjects were stimulated 3 times on both the left and right sides alternately using a 40 -s continuous 1 -cosinusoidal $0.5 \times \mathrm{Hz}$ stimulus of 2 mA:

$$
t \mathrm{t}=\operatorname{lmax}(1-\operatorname{cosinus}(2 \pi \mathrm{ft})
$$

Where $\| t=$ the actual stimulation current as a function of time, $\| \max =2 \mathrm{~mA}$ and $f=0.5$ Hz. The anterior-posterior and lateral GBS were measured during each of these last six 
monaural test sequences. The outcome of each test was expressed as the average GBS gain of all six sequences. The complete experiment consisted of five repetitions of this test per subject (Table 1 ).

\begin{tabular}{|c|c|c|c|c|c|c|c|c|c|}
\hline & \multicolumn{8}{|c|}{ Test sequences } \\
\hline & & 1 & 2 & 3 & 4 & 5 & 6 & 7 & 8 \\
\hline Test & 1 & NBS & Prestimulus & Left & Right & Left & Right & Left & Right \\
\hline Test & 2 & NBS & Prestimulus & Left & Right & Left & Right & Left & Right \\
\hline Test & 3 & NBS & Prestimulus & Left & Right & Left & Right & Left & Right \\
\hline Test & 4 & NBS & Prestimulus & Left & Right & Left & Right & Left & Right \\
\hline$\overline{\text { Test }}$ & 5 & NBS & Prestimulus & Left & Right & Left & Right & Left & Right \\
\hline
\end{tabular}

Table 1: Procedure of experiment (5 repeated tests with different time-intervals)

\section{Data analysis}

Anterior-posterior and lateral body sway were expressed in degrees to normalize the displacement of the COP for body length:

$$
\text { Body sway } \left.\left({ }^{\circ}\right)=\text { cotan [COP / }(0.56 \times \text { body length })\right]
$$

Here we assume that the centre of body mass is positioned on average at a point $56 \%$ along the length of the body (13). The frequency spectrum of the time series is calcu= lated by fast Fourier transform (FFT) using a Hamming filter and a 2048-point window. The frequency spectrum acquired with stimulation is then corrected for the background noise and NBS by subtracting the frequency spectrum acquired without stimulation. Subsequently, the average amplitude of the difference spectrum is calculated at the stimulus frequency (seven classes wide of the discrete Fourier spectrum), taken as the typical response and normalized relative to the stimulus amplitude (in milliamperes). The response is expressed in degrees/milliampere. The phase difference between stimulus and response was also calculated from the Fourier spectra (difference spectrum of the response compared to the spectrum of the stimulus).

Statistical analysis [Split-plot design, general linear model, repeated measures, MannWhitney U-test (in subgroups) and Wilcoxon Signed Rank test (in sequences)] was performed using SPSS software (version 11.0; SPSS Inc. Cary NC). 


\section{RESULTS}

\section{Short-term habituation}

The GBS gains within one test (test sequences three to eight) showed considerable variability. Fig. 1 shows the median GBS gain for all six sequences and all five tests in all subgroups. No significant differences were observed between the sequences. No significant differences were observed between the various subgroups.

Fig. 2 shows the median values of the gains of the six sequences of the first test per subgroup. There seemed to be a declining trend, despite the pre-habituating stimulus, but this was not statistically significant. Because no significant decline in gain could be observed, we calculated the average GBS gain per test. Further analysis focussed on this new parameter which we call "GBS gain".

Figs. 3 and 4 show the median values of the gains of the six sequences of the second and fifth tests, respectively per subgroup.

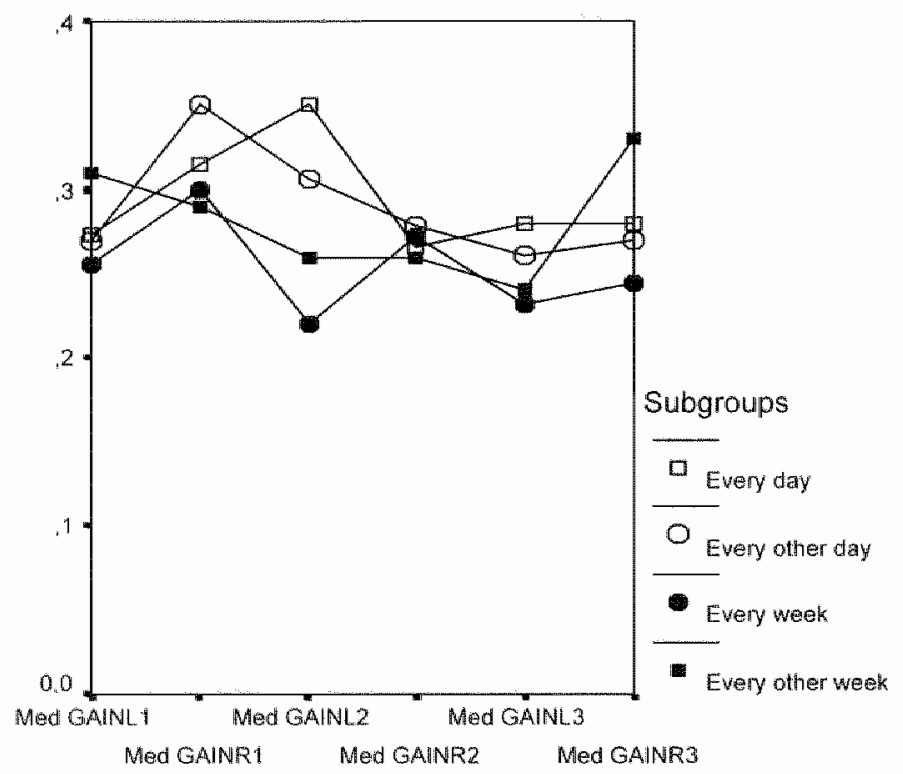

Figure 1: Short-term habituation: Median GBS gain of 5 tests 


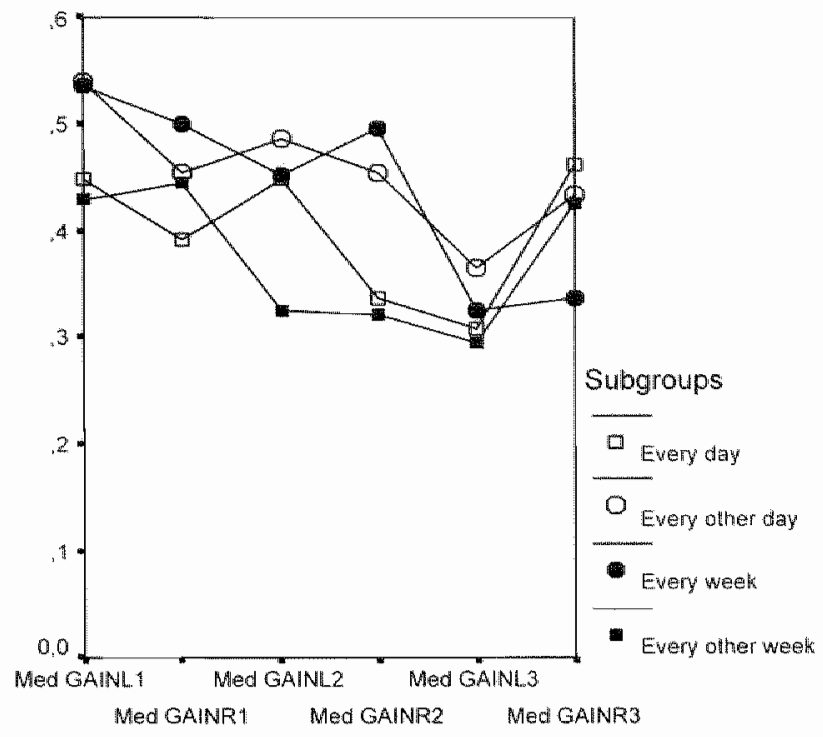

Figure 2: Short-term habituation: Median GBS gain of first test

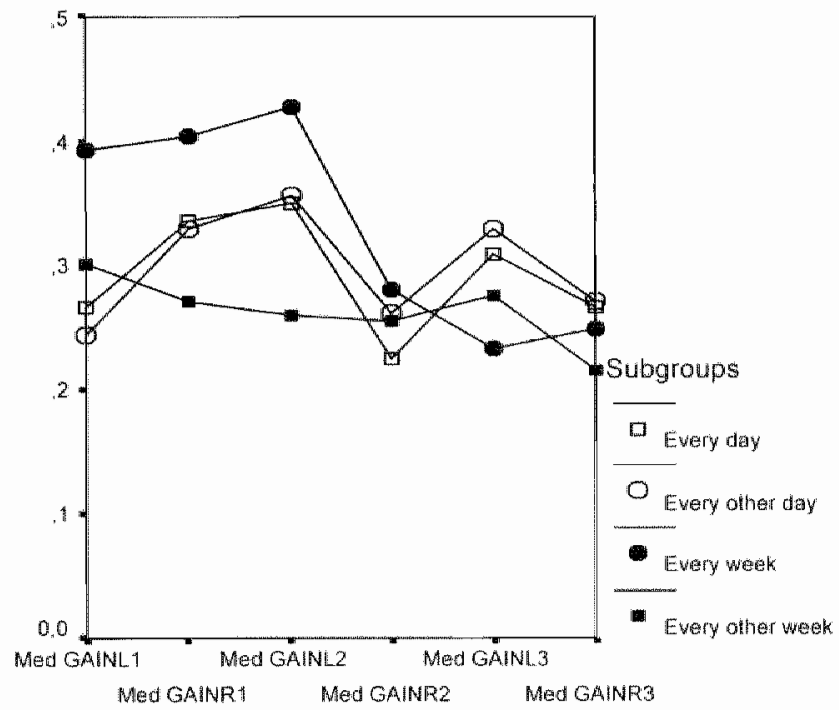

Figure 3: Short-term habituation: Median GBS gain of second test 


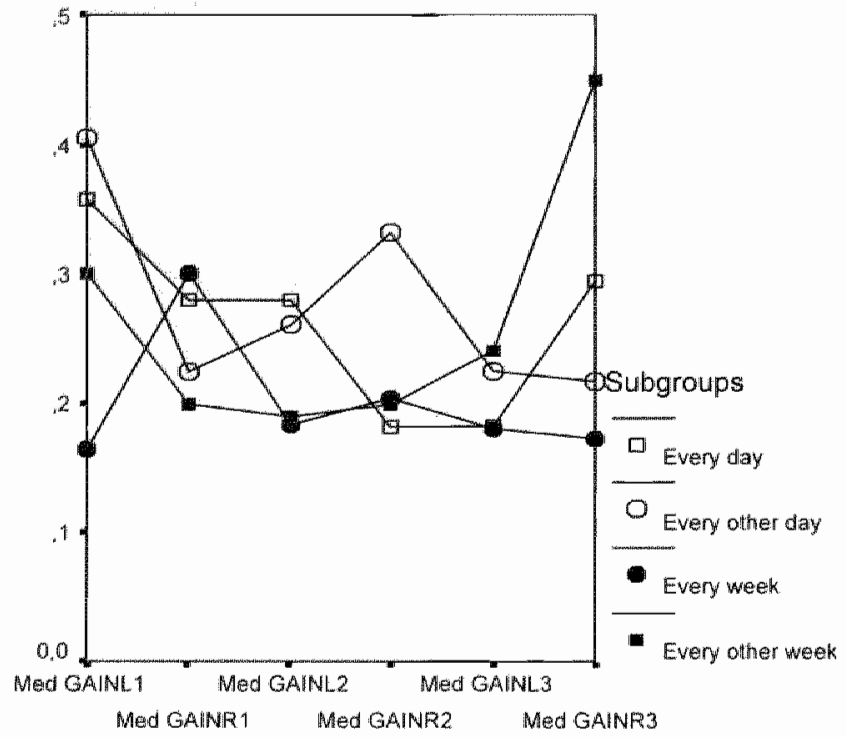

Figure 4: Short-term habituation: Median GBS gain of fifth test

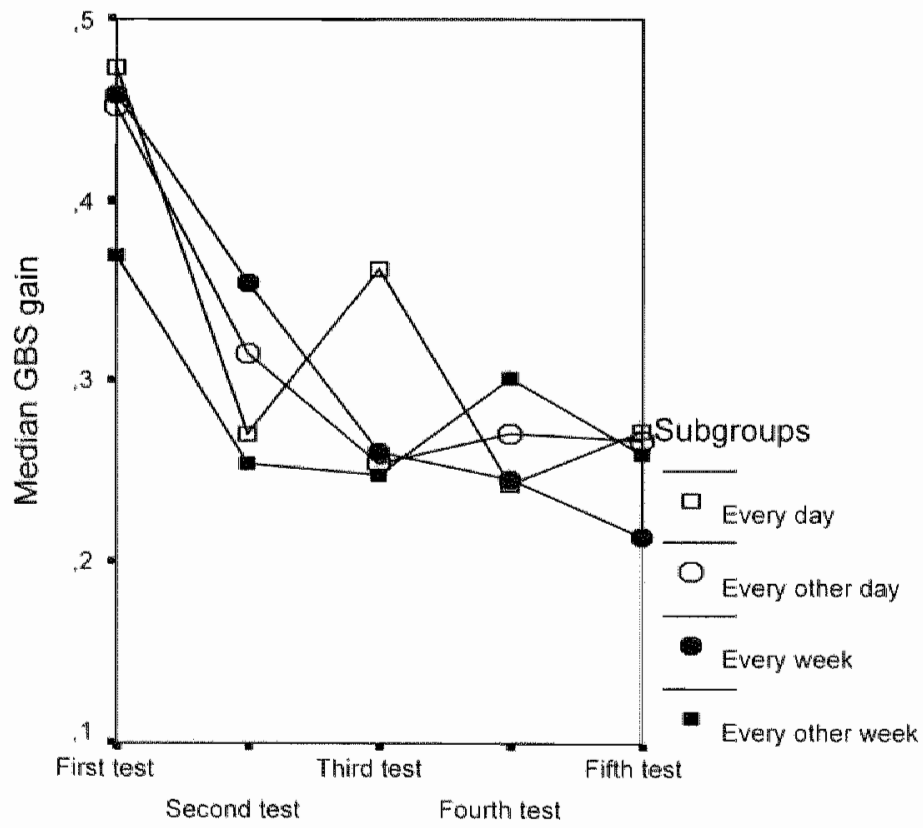

Figure 5: Long-term habituation: Median GBS gain per test 
Absolute test results did not vary with the time-interval $(p=0.217)$. Irrespective of the time-interval between the tests, a response decline was only observed after the first test $(p<0.05)$ and the response amplitudes of the $2 \mathrm{nd}, 3 \mathrm{rd}$, 4th and 5 th tests did not differ $(p>0.05 ;$ Fig. 5). Apparently, habituation only occurs after the first repetition of the test.

\section{Daily life activity, gender and GBS}

The mean GBS gain did not depend upon a subject's daily life activity or gender $(p>0.05)$.

\section{DISCUSSION}

In this paper we focused on the onset, duration and offset of the habituation process in GVS. It was expected, that a short-term response decline to GVS would occur, because nerves adapt as a result of constant stimulation, in accordance with the data of Precht et al. (9) on adaptation of primary nerve fibres of the intact frog. Courjon et al. (2) previously observed a response decline upon repetitive GVS in the rat. To our knowledge, the time course of response decline or habituation process in repeated GVS in humans has not been studied accurately to date. Based on this and our previous study (12), we observed that both short- and long-term habituation to GVS occurred. Short-term habituation occurred during testing with six consecutive monaural stimuli, and was reduced by a binaural prestimulation. This procedure allowed a reliable comparison of the GBS to left and right GVS. In the present study we confirmed the observation that the pre-habituating stimulus reduced the short-term habituation (Fig. 1). In contrast, we observed that habituation still occurred in the long term, namely there was a decline in the outcome of the complete test result (the average GBS gain of the six consecutive stimuli). However, this long-term habituation always occurred only after the first repetition of the test, irrespective of the time interval between the test (1 day-2 weeks), indicating a fast, long-lasting learning process. The outcome parameters (averaged gains) still showed variability, indicating test-retest variability and inter-individual differences in all subgroups. Many responses of the vestibular system to a variety of stimuli show considerable variability, e.g. caloric responses, rotatory tests in the dark, vestibular evoked myogenic potentials, OCR induced by lateroflexion, centrifugation or linear translation and thresholds of perception of motion. Variability seems to be more or less a common feature of the vestibular system, indicating substantial inter-subject variability and many factors that affect the testretest reproducibility (the mental state of the subject, prior knowledge, mental instruction etc.). We have studied GBS for $>10$ years and we reduced the variability considerably by identification of several independent parameters: technical aspects related to positioning and application of the electrodes (minimizing variations in the strength and shape of the electrical field induced in the head), standardizing the subject's instructions, standardiz- 
ing the position of the feet etc. Despite all these precautions, like in many other clinical vestibular tests, substantial variability remains. Our current interpretation of this phenomenon is that the response to a galvanic stimulus is also affected by negative feedback of the proprioceptive and vestibular system, counteracting the GBS. Habituation also affects the reproducibility of galvanic tests markedly. Application of the prehabituating stimulus reduced the initial response decline within one test (e.g. Fig. 2). However, the average test-responses still decreased on application of a galvanic stimulus after the first test (Fig. 5). We interpreted this response decline after the first test as a long-term habituation. Our study shows that this affect occurs irrespective of the time interval between the first and second tests (1-14 days). Use of a pre-habituating stimulus (short term) in combination with a pre-habituating first test (long term) reduced variability considerably to a non-significant level.

In this way the first step to designing a useful clinical tool was established, as reproducibility is a major prerequisite. In a previous Dutch report (unpublished data) we hypothesized that the habituation may represent the ability of the vestibular system to recognize and partially neglect a non physiological input. A recent paper by Cenciarini et al. (14) supports this hypothesis, indicating that gavanic habituation is a centrally mediated phenomenon associated with the sensory reweighting process, meaning a subject is capable of discarding irrelevant stimuli. It would be interesting to study the habituation phenomenon with longer time intervals (>2 weeks) between the tests, in order to obtain more accurate information on the on-and offset of the habituation phenomenon and the learning abilities of the vestibular system.

We conclude from this study that the procedure we have developed to assess GBS can be used as a clinical test, by performing a first test to habituate the system, followed by a second test to quantify the sensitivity (GBS gain). In this way the Iong-term habituation phenomenon is assessed and bypassed. After the second measurement, habituation no longer occurs. In our ongoing research we have used the measuring protocol described here to study vestibular schwannoma patients and to quantify the vestibular sensitivity of the vestibullar system in professional gymnasts and in carsick subjects. The improved reproducibility of the test allowed us to draw firm conclusions, and convinced us of the possible usefulness of the galvanic test as a clinical tool. Our research is now focused on this clinical applicability. 


\section{REFERENCES}

1. Kandel ER, Schwartz JH, Jessel TM. Principles of neural science. In. third ed. New York: Elsevier Science Publishing co.; 1991. p. 506

2. Courjon J, Precht $W$. Sirkin D. Vestibular nerve and nuclei responses and eye movement responses to repetitive galvanic stimulation of the labyrinth in the rat. Exp. Brain Res. $1987: 66: 41-48$.

3. du Lac S, Lisberger SG. Cellular processing of temporal information in medial vestibular nucleus neurons. I Neurosci 1995;15(12):8000-10.

4. Andrew $F$, Teich, Qian $N$. Learning and adaptation in a recurrent model of $V 1$ orientation selectivity. I Neurophysiol april 2003;89:2086-2100.

5. Ahn SC, Lee $\mathrm{CY}$, Kim DW, Lee MH. Short-term vestibular responses to repeated rotations. J. Vest. Res. 2000; 10(1):17-23.

6. Barnes $G$. Adaptation in the oculomotor response to caloric irrigation and the merits of bithermall stimulation. Br. J. Audiol. 1995;29(2):95-106.

7. Bock $\mathrm{O}$, von Koschitzky $\mathrm{H}$, Zangemeister WH. Vestibular adaptation to long-term stimuli. Biol Cybern. 1979;33(2):77-79.

8. Lowenstein $0 J$. The effect of galvanic polarization on the impulse discharge from sense endings in the isolated labyrinth of the thornback ray (raja clavata). Physiol. 1955;127:104-117.

9. Precht $W$, Llinas $R$, Clarke $M$. Physiological responses of frog vestibular fibers to horizontal angular rotation. Exp Brain Res 1971:13(4):378-407.

10. Hallpike CS, Hood JD. Fatigue and adaptation of the cupular mechanisms of the human horizontal semicircular canal: an experimental investigation. In: Proc. roy. Soc. B.; 1953; 1953. p. $542-567$.

11. Albert HHv. Untersuchungen zur habituation des postrotatorischen nystagmus. Dtsch. $Z$ Nervenheillk. 1965;187:503-506.

12. Balter $S G$, Stokroos RJ, Boumans R, Kingma $H$. Background on methods af stimulation in galvanic-induced body sway in young healthy adults. Acta Otolaryngol 2004;124(3):262-71.

13. Winter DA. Biomechanics of human movement. New York: Wiley \&Sons; 1979.

14. Cenciarini M. Peterka R. Horak F. Habituation to galvanic vestibular stimulation depends on sensory reweighting. J Vest. Res. 2001/2002;11(3-5):288. 



\section{Chapter 5}

\section{Habituation to galvanic vestibular stimulation for analysis of susceptibility to carsickness}

Susanne G.T. Baller, Robert J. Stokroos, Maikel M.M. Van De Laar, Nadia Hendrice, Herman Kingma Accepted for publication in Acta Otolaryngol 


\section{ABSTRACT}

Objective - In a previous study we developed a standardized procedure for a reproducible quantification of galvanic-induced body sway (GBS). In line with other reports, GBS shows short-term (fast) habituation upon stimulus repetition. The aim of this study was to evaluate whether the degree of short-term habituation to galvanic vestibular stimulation (GVS) is correlated with susceptibility to carsickness.

Materials and Methods - A total of 24 female subjects underwent computer-controlled GVS as part of a prospective experimental study conducted in a tertiary referral center. A binaural 1-cosinusoidal stimulus of $0.5 \mathrm{~Hz}$ and $1 \mathrm{~mA}$ was repeated five times. Binaural stimulation was chosen to obtain maximum responses, making possible habituation to repetitive GVS obvious. The groups consisted of 12 subjects suffering from carsickness and 12 healthy subjects.

Results - The analysis of the repeated measurements test showed that the GBS gain curve of the carsickness group was always superimposed on that for the healthy subjects. However, the (absolute) first to fifth GBS gains showed no significant differences ( $p=0.134$ to $p=0.995$ ). When comparing short-term habituation in subjects suffering from carsickness versus healthy subjects, results showed no difference in the mean values of the first $(30.534 \%$ versus $27.024 \%)$, final $(42.637 \%$ versus $38.544 \%)$ and average $(35.544 \%$ versus $33.644 \%)$ habituation $(p=0.875, p=0.991$ and $p=0.951$, respectively).

Conclusion - We did not observe any significant differences in sensitivity or habituation of the GBS in carsick subjects compared to healthy subjects. This implies that carsick subjects show a similar ability to discard an irrelevant, non-motion sickness-inducing galvanic stimulus as healthy subjects.

Key words: carsickness, galvanic vestibular stimulation, short-term habituation

\section{INTRODUCTION}

In previous studies we observed that healthy subjects habituate to galvanic vestibular stimulation (GVS) withim minutes and for up to at least 2 weeks $(1,2)$. In a previous Dutch report (2) we hypothesized that this habituation may represent the ability of the vestibular system to recognize and partially neglect a non-physiological input. A paper by Cenciarini et al. (3) supports this hypothesis, indicating that galvanic habituation is a centrally mediated phenomenon associated with the sensory reweighting process, meaning a subject is capable of discarding irrelevant stimuli.

The sensory conflict theory is almost universally accepted as a means of explaining motion sickness, e.g. carsickness. According to this theory, motion sickness occurs when there is a intersensory mismatch involving conflicting sensory signals (visual, vestibular and somatic) and prediction of such inputs as made by the central nervous system $(4,5)$. Loss of awareness of the orientation relative to the gravity vector resulting from the sensory mismatch seems to be a crucial factor in the induction of motion sickness in general 
(6). The sensitivity to motion sickness seems to decrease when subjects are repeatedly exposed to the complex stimulus condition; learning to interpret the condition and discarding of irrelevant stimuli play a major role (similar to habituation to GVS, as mentioned above). Training of each of the levels of the sensorimotor chain (i.e. somatosensoric, visual and vestibular) may improve balance control under complex conditions (710). The identification and correct interpretation of complex stimulus conditions seem to be an important aspect in motion sickness and in sport (11). In this study we hypothesize that short-term habituation to GVS (discarding of irrelevant stmuli) is less in subjects suffering from carsickness than in healthy subjects.

\section{MATERIALS AND METHODS}

\section{Subjects}

The study subjects were as follows: Group 1, 12 female subjects suffering from carsickness (mean age 25 years; range 19-35 years); Group 2, 12 healthy female subjects (mean age 25 years; range $20-34$ years).

Inclusion criteria (all subjects): Age: 19-35 years; female gender (in order to exclude a sex-dependent bias). Inclusion criteria (Group 1): subjects who experienced symptoms such as dizziness, nausea, retching and vomiting during passive motion in a car. Only therapy-resistant (habituation, cinnerizine, scopolamine) subjects with a $>1$ year history of carsickness as a passenger in a car were included.

Exclusion criteria: a history of better than average motor or balance skills (ballet dancers, gymnasts, and semi-professional sportsmen) and a history of vestibular, musculoskeletal or neurological disorders. Subjects were not using any medication that could affect the vestibular or musculoskeletal systems. Alcohol consumption was prohibited for $24 \mathrm{~h}$ prior to testing.

\section{Materials}

A computer-controlled stimulator, built in our department and meeting the appropriate safety regulations (IEC 601.1), generated the galvanic stimulus described below. The stimulator is equipped with a feedback mechanism so that an identical galvanic stimulus can be applied to every subject tested, irrespective of the electrical conductivity of skin and temporal bone. The electrodes measure $50 \times 35 \mathrm{~mm}^{2}$ and are composed of silicon rubber, mixed with conducting carbon particles (CEFAR MM Medical Products, Lund, Sweden). The electrodes were attached to the retro-auricular skin with electroconductive adhesive gel (Tac Gelrm). Movements of the centre of pressure (COP) were measured using a force platform (42 x $35 \mathrm{~cm}^{2}$; Jaeger-Toennies $\mathrm{GmbH}$. Wurzburg, Germany) equipped with four transducers, one at each corner. Data-acquisition (50-Hz sampling 
rate) and analysis were performed using a T-Post-Nystagliner computer system (JaegerToennies $\mathrm{GmbH}$ ).

\section{Procedure}

In all subjects, caloric testing was performed first to exclude vestibular function loss or asymmetry. None of the subjects showed function loss or asymmetry on caloric stimulation and thus they were selected for further testing. Prior to testing the retro-auricular skin was cleaned with petroleum ether and Tac Gel ${ }^{\text {TM }}$ was applied to three electrodes. The gel was allowed to dry for five min to improve adhesion to the skin. We placed two electrodes at the mastoid, one behind each ear. A third electrode was placed on the neck at the $\mathrm{C} 7$ vertebra (1). The electrodes were fixed with adhesive tape (Mefix(e)). Subjects wore headphones in order to optimize retro-auricular stabilization of the electrodes and reduce auditory spatial orientation. During each test, lights in the test cabin were dimmed and the subjects were ordered to keep their eyes closed to prevent any visulal orientation. Subjects were instructed to stand upright in bare closed feet (inter-foot distance $0 \mathrm{~cm}$ ) on the force platform with their arms crossed in front of their body. The test cabin was provided with a frame surrounding, which did not touch the subject, in order to prevent a fall in the case of severe imbalance. The following test sequence was used. First, the natural body sway (NBS) of each subject was measured without any stimulation for $40 \mathrm{~s}$ (zero reference). Next, the subjects received a binaural stimulus consisting of a 40-s continuous 1-cosinusoidal $0.5 \mathrm{~Hz}$ stimulation of $1 \mathrm{~mA}$. This test sequence (binaural stimulation) was repeated five times. The lateral GBS-glain was measured for each of these test sequences.

\section{Data analysis}

Lateral sway was expressed in degrees to normalize the displacement of the COP for body length:

$$
\text { Body sway }\left({ }^{\circ}\right)=\text { cotan }[\text { COP } /(0.56 x \text { body length })]
$$

Here we assume that the centre of body mass is positioned on average at a point $56 \%$ along the length of the body (12). The frequency spectrum of the time series is calculated by fast Fourier transform (FFT) using a Hamming filter and a 2048-point window. The frequency spectrum acquired with stimulation is then corrected for the background noise and the NBS by subtracting the frequency spectrum acquired without stimulation. Subsequently, the average amplitude of the difference spectrum is calculated at the stimulus frequency ( 7 classes wide of the discrete Fourier spectrum), taken as the typical response and normalized relative to the stimulus amplitude (in milliamperes). The response is expressed in degrees per milliampere. The phase difference between the stimulus and response was also calculated from the Fourier spectra (difference spectrum of the response compared to the spectrum of the stimulus). First habituation [100x(gain1gain 2)/gain1] measured the difference betweem the first gain (gain1) and the second gain 
(gain2). Final habituation [100x(gain1-gain5)/gain1] measured the decrease in gain comparing the first (gainl) and the last gain (gain5). Average habituation $100 \times$ (gain 1 gain2)/gain 1 + (gain 1-gain3)/gain1 +(gain 1-gain4)/gain 1 +(gain1-gain5)/gain1]4) measured the average decrease in gain 1 compared to gains $2-5$. The average gain was calculated using the following formula:

$$
\text { average gain }=100 \times[(\text { gaim } 1+\text { gain } 2+\text { gain } 3+\text { gain } 4+\text { gain } 5) / 5]
$$

Statistical analysis (Mann-Whitney U-test, General Linear Model, Kolmogorow-Smimov test) was performed using SPSS software (version 11.0; SPSS Inc., Cary, NC).

\section{RESULTS}

\section{GBS gains in subjects suffering from carsickness and healthy subjects}

The distribution of GBS gains did not differ from normal ( $p>0.448$; Kolmogorov-Smirnov test).

In healthy subjects the mean GBS gain decreased upon repetition from 2.710 to $1.705^{\circ} / \mathrm{mA}$. Subjects suffering from carsickness showed a mean GBS gain that decreases upon repetition from 3.305 to $1.751 \% \mathrm{~mA}$ (Fig. 1). Analysis of the repeated measurements test showed that the GBS gain curve for the carsickness-group was always superimposed on that for the healthy subjects (Fig. 1). However, the (absolute) first to fifth GBS gains showed no significant differences ( $p=0.134-0.995)$ (Fig. 1).

The SD's of the initial GBS gain were large in the healthy subject group and in the carsickness group ( 1.373 and $\$ .288^{\circ} / \mathrm{mA}$, respectively) (Fig. 2).

These two findings indicate that predictions of susceptibility to carsickmess cannot be based on GBS gains.

\section{Short-term habituation in subjects suffering from carsickness and healthy subjects}

When comparing short-term habituation in subjects suffering from carsickness and healthy subjects, the results showed no difference in the mean values of the first (30.534\% vs $27.024 \%$ ), final (42.637\% vs $38.544 \%$ ) and average (35.544\% vs $33.644 \%$ ) habituation ( $p=0.875, p=0.991$ and $p=0.951$ ) (Fig. 1). The SD's of the habituation were large in the healthy subject group and in the carsickness group (first habituation: $\mathrm{SD}=24.258 \%$ and $27.119 \%$ (Fig. 3); finall habituation: $\mathrm{SD}=23.921 \%$ and $26.550 \%$ (Fig. 4); average habituation: $S D=22.937 \%$ and $22.622 \%$ (Fig. 5)). The degree of shortterm habituation to galvanic vestibular stimulation is thus not correlated with susceptibility to carsickness. 


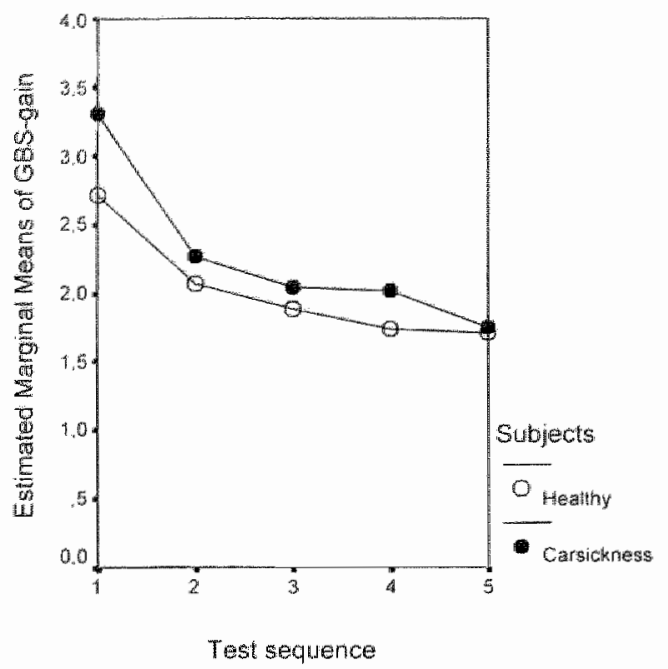

Figure 1: Estimated marginal means of GBS gain: heaithy subjects versus subjects suffering from carsickness

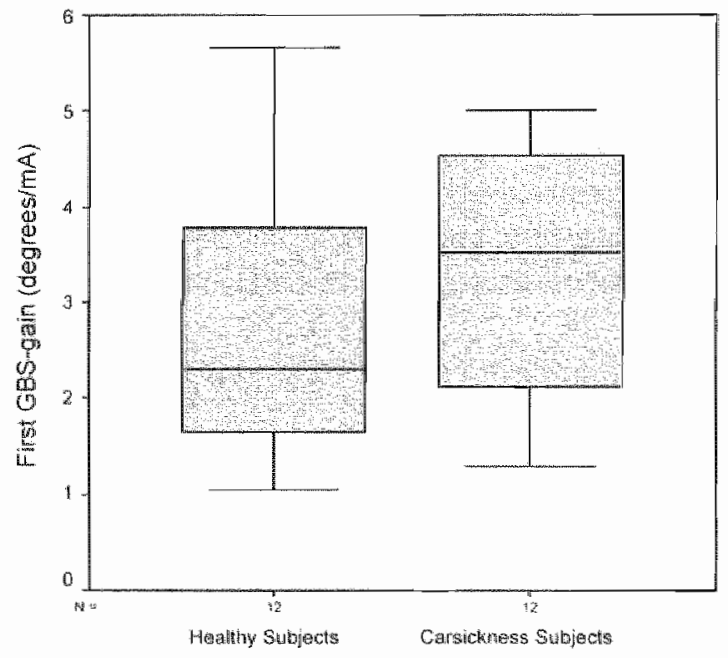

Figure 2: Boxplots of the (absolute) first GBS gain: healthy subjects versus subjects suffering from carsickness 


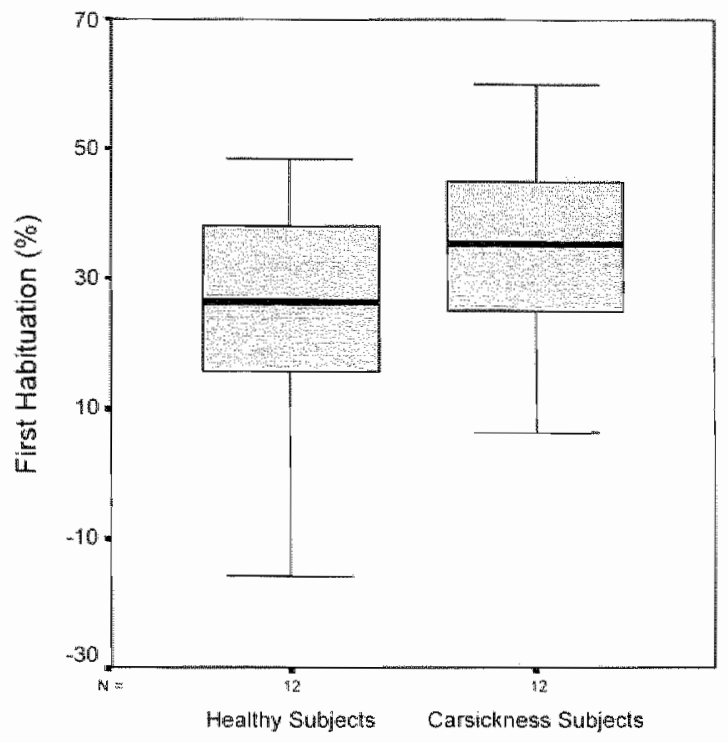

Figure 3: Bioxplats of the first habituation: healthy subjects versus subjects suffering from carsickness

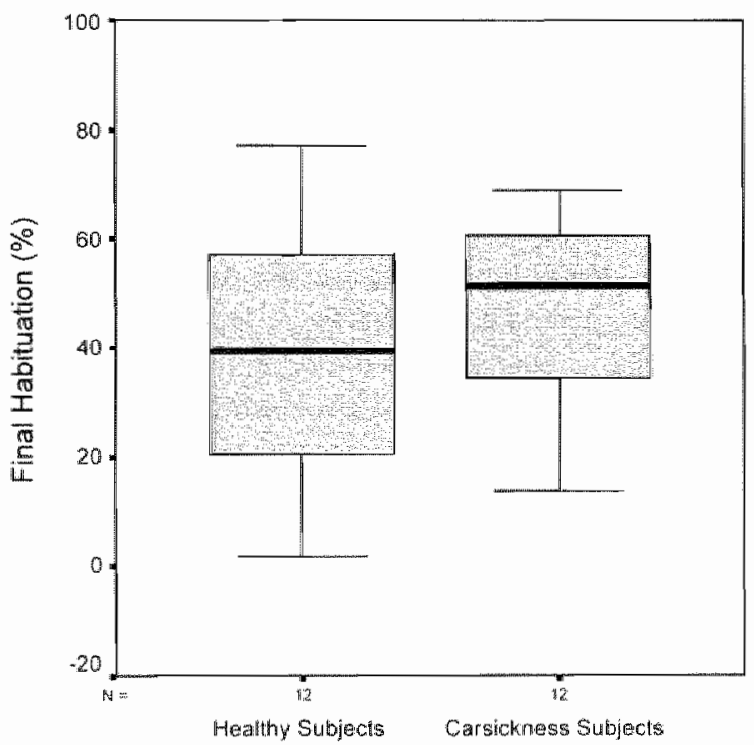

Figure 4: Boxplots of the final habituation: healthy subjects versus subjects suffering from carsickness 


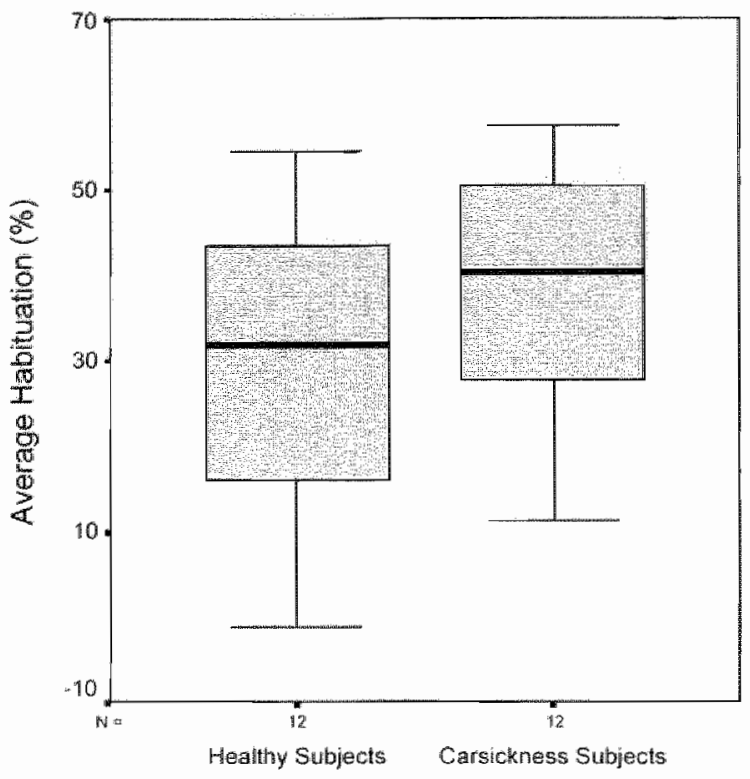

Figure 5: Box-plots of the average habituation: healthy subjects versus subjects suffering from carsickness

\section{DISCUSSION}

In this study the relation between susceptibility to carsickness and the degree of shortterm habituation (2) to galvanic vestibular stimulation (GVS) was analyzed. In order to exclude a gender-dependent bias all of our subjects who suffered from carsickness were fernale (13). It is well known that repetitive exposure to motion sickness-inducing conditions often leads to habituation and reduction in symptoms (11), unless subjects are particularly sensitive to motion sickness and develop related anxieties. Healthy subjects also habituate to repetitive rotatory and caloric stimuli in laboratory conditions. In many subjects with a high sensitivity to motion sickness, caloric (14) and rotatory stimulation (15) induce similar symptoms as in motion sickness, but substantial habituation rarely occurs. These sensitive subjects often report substantial fear of repetition of these tests and often show increasing responses (hyperactivity). Hyperventilation and anxiety generally lead to hyper-responses to vestibular stimulation too (16). These observations suggest that the initial response to vestibular stimuli (natural and artificial) is strongly affected by anxiety and that substantial habituation only occurs in healthy, non-anxious subjects who can cope with the stimulus patterns (pattern recognition). 
In our study, GVS did not lead to motion sickness symptoms, and habituation occurred in both groups. Analysis of the repeated measurements test showed that the GBS gain curve of the carsickness group was always superimposed on that of the heallhy subjects. However, the (absolute) first to fifth GBS gains showed no significant differences.

When comparing short-term habituation in subjects suffering from carsickness and healthy subjects, results showed no differences in the mean values of the first, final and average habituation. We therefore reject our hypothesis that carsickness is associated with poor habituation to GVS. In contrast to our hypothesis, the response decline to GVS was not significantly different when comparing the carsickness group with the healthy subjecits.

There may have been a difference between the GBS parameters in the two groups that was not apparent in our study because of the relatively small sample size. However, the major point is which difference should be considered to be relevant. We wanted to be able to identify any subject as either normal or carsick based on the GBS parameters. We therefore calculated beforehand the power, needed to show a clinically relevant difference between the carsick and healthy subjects, which led to a required minimum sample size of nine, given the variance of 0.08 observed in our previous study. To summarize, our study had sufficient power to show a clinically relevant difference between normal and carsick subjects, which was not observed. Use of a larger sample size may have shown smaller but clinically irrelevant differences and relatively weak correlations.

Habituation behavior induced by GVS did differ from that induced by caloric or rotatory stimulation or that induced by car motion. Healthy subjects show normal initial responses and habituate to GVS, ratatory and caloric stimulation and vehicle motions (ships, cars, planes). Carsick subjects often show initial high responses to rotatory and caloric stimulation and vehicle motions, but normal responses to GVS. Carsick subjects do not habituate effectively to the previously mentioned stimuli, but habituate normally lo GVS without experiencing motion sickness symptoms.

The SD's of the initial GBS gain and the first habituation were large in both groups. This indicates that the sensitivity and fast habituation to GVS are not strong indicators of carsickness.

\section{CONCLUSION}

We did not observe any significant differences in sensitivity and habituation of the GBS in carsick subjects compared to healthy subjects. This implies that carsick subjects show a similar ability to discard an irrelevant, non-motion sickness-inducing galvanic stimulus as healthy subjects. 


\section{REFERENCES}

1. Balter $\mathrm{SG}$, Stokroos RJ, Boumans R. Kingma H. Background on methods of stimulation in galwanicunduced body sway in young healthy aduls. Acta Otolaryngol 2004;124(3):262-71.

2. Balter $S G$. Stokroos RJ "Eterman RM, Paredis SA, Orbons J, Kingma H. Habituation to galvanic vestibular stimulation. Accepted for publication in Acta Otolaryngol.

3. Cenciarini M. Peterka R. Horak F. Habituation to galvanic vestibular stimulation depends on sensory reweighting. J. Vest. Res. 2001/2002;11(3-5):288.

4. Warwick-Ewans LA, Symons $N$, Fitch $T$, Burrows $L$. Evaluating sensory conflict and postural instability. Theories of motion sickness. Brain Res Bull 1998:47( 5):465-469.

5. Takeda $N$, Morita $M$, Horii $A_{u}$ Nishilke $S$, Kithahara $T$. Uno A. Neural mechanisms of motion sickness. J Med Invest 2001;48(1-2);44-59.

6. Bles W, Bos JE, de Graaf B, Groen E, Wertheim AH. Motion sickness; Only one provocative conflict? Brain Research Bulletin 1998;47(5):481-487.

7. Hlavacka F, Mergner T, Schweigart $G$. Interaction of vestibular and proprioceptive inputs for human self-motion perception. NHeurasc. Lett. 1992;138:161-164

8. Perrin $P$, Béné MC, Perrin $C$, Durupt $D$. Ankle trauma significantly impairs posture control: a study in basketball players and controls. Int J. Sports Med. 1997:18:387-392.

9. Vidal PP. Bierthoz $A_{n}$ Millavoye $M$. Difference between eye closure and visual stabilization in the control of posture in man. Aviat. Space Environ. Med. 1982;53:166-178.

10. Perrin $P$, Schneider D, Deviterne D, Perrot $C$, Constantinescu $L$. Training improves the adaptation to changing visual conditions in maintaining human posture control in a test of sinusoidal ascillation of the support. Neuroscience Letters 1998;225:155-158.

11. Vuillerme $N$. Teasdale $N$, Nougier $V$. The effect of expertise in gymnastics on proprioceptive sensory integration in human subjects. Neurosci Lett 2001;311(2):73-6.

12. Winter DA. Biomechanics of human movement. New York: Wiley \&Sons; 1979.

13. Sharma K, Aparna. Prevalence and correlates of susceptibility to motion sickness. Acta Genet Med Gemellol (Roma) 1997:46(2):105-21.

14. Malinson AI, Longridge NS. Motion sickness and westibular hypersensitivity. The Journal of Otolaryngology 2002;31(6):381-385.

15. Denise P. Etard O, Zupan $L_{\text {" }}$ Darlol $C$. Motion sickness during off-verticall axis rotation: prediction by a model of sensory interactions and correlation with other forms of motion sickness. Neuroscience Letters 1996;203(3):183-186

16. Theunissen $E \mathcal{U}$. Huygen PL. Folgering HT. Vestibular hyperreactivity and hyperventilation. Clin Otolaryngol 1986;11(3):161-9. 


\section{Chapter 6}

\section{Habituation to galvanic vestibular stimulation for analysis of postural control abilities in gymnasts}




\section{ABSTRACT}

The possible correlation between postural control abilities in gymnasts and the sensitivity for and the degree of short-term habituation to galvanic vestibular stimulation (GVS) was studied. Seven balance trained young girls (Dutch National Junior Gymnasts Championship) versus seven non-trained girls and twenty-five women underwent computer controlled GVS using a monaural continuous 1-cosinusoidal stimulus of $0.5 \mathrm{~Hz}$ and $2 \mathrm{~mA}$. repeated three times on each side $(1,2)$. Results showed that mean total galvanicinduced body sway (GBS) gain was significantly lower in the trained and untrained girls compared to the adult women $(p<0.05$ ). Mean habituation to GVS (learning abilities) however showed no significant differences between the three groups. We suggest that the superior balance control in professional gymnasts is primarily achieved through motor training and not by learning abilities or a higher sensitivity of the vestibular system (3). Key words: galvanic vestibular stimulation, habituation, professional gymnasts

\section{INTRODUCTION}

In previous studies we observed that healthy subjects habituate to galvanic vestibular stimulation (GVS) within minutes and lasting for at least two weeks (1,2). in a previous Dutch report we hypothesized that the habituation might show the ability of the vestibular system to recognize and partially neglect the non-physiological galvanic input thanks to visual or somatosensoric feedback induced by the elicited body sway itself. A paper by Cenciarini et al. (4) supports this hypothesis, indicating that galvanic habituation is a centrally mediated phenomenon associated with the sensory reweighting process, meaning a subject is capable of discarding irrelevant stimuli.

Training of each of the levels of the sensory-motor chain (i.e. somatosensoric, visual and vestibular) may improve balance control in complex conditions (5-7). Perrin et al. (3) suggested that training improves adaptive postural control. Intensively trained gymnasts seem to be able to rapidly reorganize the hierarchy among sensory inputs to ensure adequate postural control in complex conditions. This finding is also seen in judoists and dancers, indicating a positive effect of training on sensorimotor adaptability (8). Vuillerme et al. (9) objectified that gymnasts present the particularity of being less dependant on visual cues than other sportsmen for maintaining balance in challenging postures. Also, dynamic posturography-tests show that postural control has developed better in gymnasts, compared to controls (10). Identification and correct interpretation of complex stimulus conditions seem to be an important aspect in sports (10).

In the current study we investigate whether short-term habituation to GVS (discarding the irrelevant galvanic stimulus) is correlated to the sensitivity of highly trained gymnasts to cope with complex movements and stimuli. 


\section{MATERIALS AND METHODS}

\section{Subjects}

Thirty-nine subjects participated in this study; they were subdivided in three groups: Group 1: Seven highly balance trained female gymnasts that were selected for Dutch National Junior Gymnasts Championship (mean age 11.7 years, range $11-13$ years) Group 2: Seven female subjects that had no specific balance training (mean age 11.9 years, range $10-13$ years)

Group 3: Twenty-five female (middle-aged) subjects that had no specific balance training (mean age 24.8 years, range $20-48$ years)

All subjects were female to exclude a gender-dependent bias. Exclusion criteria for groups 2 and 3 were a history of more than average motor or balance skills (ballet dancers, gymnasts, and semi-professional sportsmen). Exclusion criteria for all subjects were a history of vestibular, musculoskeletal or neurological disorders. Subjects did not use any medication that could affect the vestibular or musculoskeletal system. Alcohol consumption was prohibited for 24 hours prior to testing.

\section{Procedure}

A computer-controlled stimulator built in our department and meeting the appropriate safety regulations (IEC 601.1) generated the galvanic stimulus described below. The stimulator is provided with a feedback mechanism so that an identical galvanic stimulus can be applied to every subject tested, irrespective of the electrical conductivity of skin and temporal bone. The electrodes measure $50 \times 35 \mathrm{~mm}^{2}$ and are composed of silicon rubber, mixed with conducting carbon particles (CEFAR Medical Products, Lund, Sweden). The electrodes were attached to the retro-auricular skin with electroconductive adhesive gel (Tac Gelm). Movements of the centre of pressure (COP) were measured using a force platform (42 $\times 35 \mathrm{~cm}^{2}$; Jaeger-Toennies $\mathrm{GmbH}$, Wurzburg. Germany) equipped with four transducers, one at each corner. Data-acquisition (50 $\mathrm{Hz}$ sampling rate) and analysis were performed using a T-Post-Nystagliner computer system (JaegerToennies $\mathrm{GmbH}$ ).

\section{Data analysis}

In all subjects (groups 1-3) we first determined length, weight and body mass index (BMI). Next, motor abilities were quantified by use of the composite score of dynamic posturography [(sensory organisation test)(SOT)] (11) using a T-Post system (JaegerToennies $\mathrm{GmbH}$ ), with implementation of the SOT as defined in the Equitest system produced by Neurocom Int. After this all subjects underwent GVS. Prior to testing, the retroauricular skin was cleaned with petroleum ether and Tac Geltim applied to three electrodes. The gel was allowed to dry for five min to improve adhesion to the skin. We 
placed two ectrodes at the mastoid, one behind each ear. A third electrode was placed on the neck at the $C 7$ vertebra (1). The electrodes were fixed with adhesive tape (Mefix(e) ). In order to optimize retro-auricular stabilization of the ellectrodes and reduce auditory spatial orientation a headphone was worn by the subject. During each test, lights in the test-cabin were dimmed and the subject's eyes closed to prewent any visual orientafion. Each subject was instructed to stand upright with bare closed feet (inter-feet distance $0 \mathrm{~cm}$ ) on the force platform with the arms crossed in front of the body. The test cabin was provided with a frame surrounding, which did not touch the subject, to prevent a fall in the case of severe imbalance. The following test sequence was used in this sample: First, the natural body sway (NBS) of each subject was measured without any stimulation for $40 \mathrm{~s}$ (zero-reference). Next, the subjects received a prestimulus consisting of a 40 -s continuous binaurall sinusoidal $0.5-\mathrm{Hz}$ stimulation of $1 \mathrm{~mA}$ (1). Finally, the subjects were stimulated on the left $(L)$ and right $(R)$ sides atternately 3 times using a $40-5$ continuous 1-cosinusoidal $0.5-\mathrm{Hz}$ stimulus of $2 \mathrm{~mA}$.

The test outcome was expressed as the mean total gain of the lateral galvanic-induced body sway (GBS gain) of all six test sequences in degrees per milliampere:

$$
\text { mean total gain = (GAINL1+GAINR1+GAINL2+GAINR2+GAINL3+GAINR3)/6 }
$$

The habituation observed at the second stimulation, compared to the first, was defined by:

$$
\text { HAB12 (=100* (gain1-gain2)/gain1) }
$$

Habituation compared to the first stimulus that occurred at the third, fourth, fifth and sixth stimulation, similarly:

$$
\begin{aligned}
& \text { HAB13 (=100* (gain1-gain3)/gain1) } \\
& \text { HAB14 (=100* (gain1-gain4)/gain1) } \\
& \text { HAB15 (=100* (gain1-gain5)/gain1) } \\
& \text { HAB16 (=100* (gain1-gain6)/gain1) }
\end{aligned}
$$

The mean total habituation (HAB) was defined by:

$$
\mathrm{HAB}=((\mathrm{HAB} 12)+(\mathrm{HAB} 13)+(\mathrm{HAB14})+(\mathrm{HAB} 15)+(\mathrm{HAB16})) / 5
$$

Body mass index (BMI) is calculated as follows:

$$
\mathrm{BM}=\text { weight }(\mathrm{kg}) /\left[(\text { length }(\mathrm{m})]^{2}\right.
$$

Lateral sway was expressed in degrees per milliampere (degs/mA) and the displacement of the COP was normalized for body length:

$$
\text { Body sway }\left({ }^{\circ}\right)=\operatorname{cotan}[\text { COP } /(0.56 \times \text { body length })]
$$

Here we assume that the centre of body mass is positioned on average at a point $56 \%$ along the length of the body (12). Fast Fourier transform (FFT) using a Hamming filter and a 2048-point window calculates the frequency spectrum of the time series. The frequency spectrum acquired with stimulation is then corrected for the background noise 
and the NBS by subtracting the frequency spectrum acquired without stimulation. Subsequently, the average amplitude of the difference spectrum is calculated at the stimulus. frequency ( 7 classes wide of the discrete fourrier spectrum), taken as the lypical re. sponse and nomalized relative to the stimulus amplitude (in milliamperes). The response is expressed in degs $/ \mathrm{mA}$. Statistical analysis (Mann-Whithey U-test "Independent Samples Test, Kolmogorov-Smirnov Test for Nomality) was performed using SPSS software (version 11.0; SPSS Inc., Cary, NC).

\section{RESULTS}

Length, weight and body mass index (BMI)

Results show that professional gymnasts are significantly shorter (Fig. 1) and lighter (Fig. 2) than untrained girls ( $p=0.001$ and $p=0.024$ ) or women $(p<0.001$ and $p<0.001)$.

The mean value of the computed body mass index (BMI) (Fig. 3 ) is 18.36 in young un trained girls versus 18.63 in gymnasts and 23.01 in women. BMI is not significantly different between trained and untrained girls $(p=0.844)$, but significantly higher in adult women $(p<0.005)$.

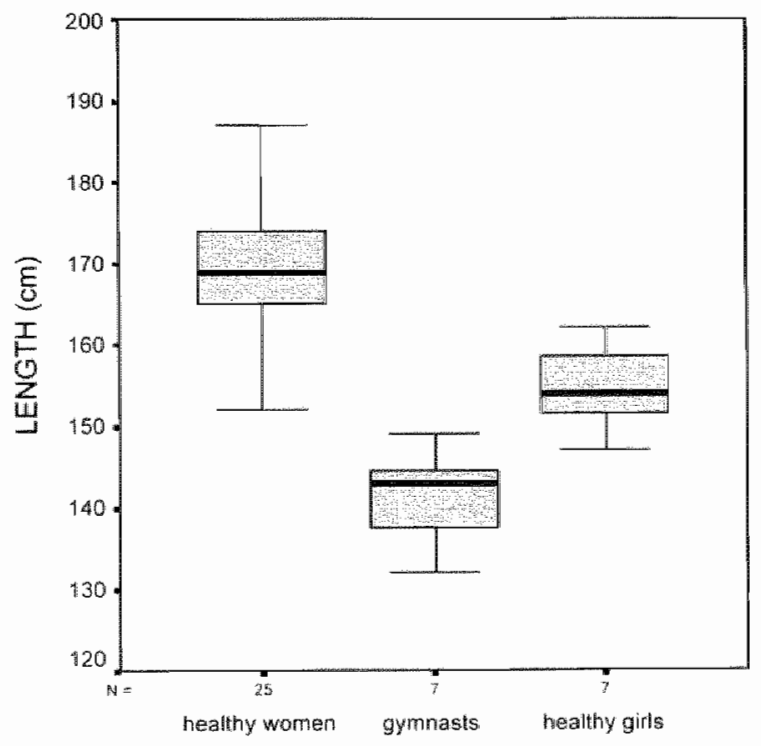

Figure 1: Length $(\mathrm{cm})$ of professional gymnasts versus untrained girls and women 


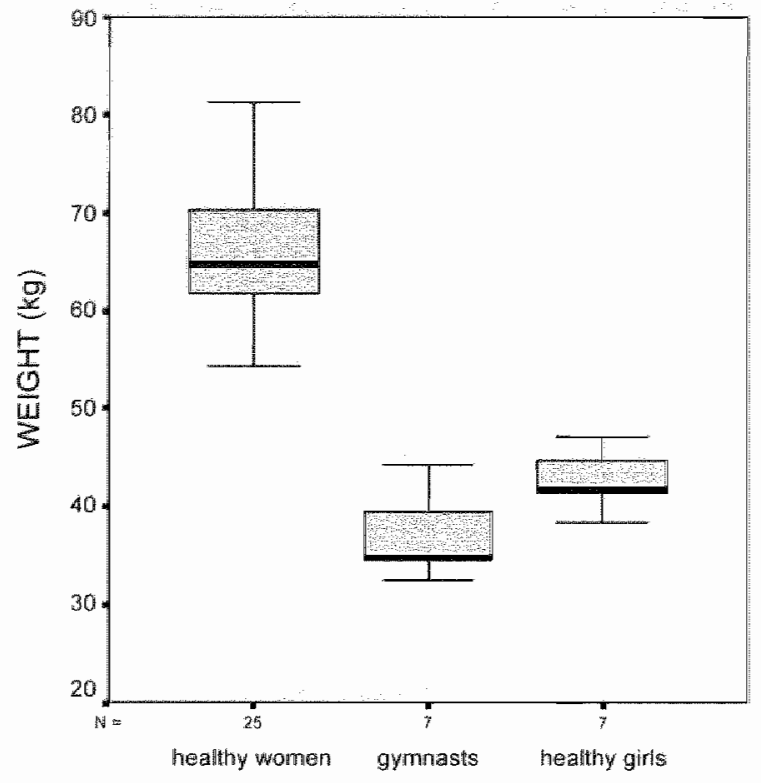

Figure 2: Weight (kg) of professional gymnasts versus untrained girls and women

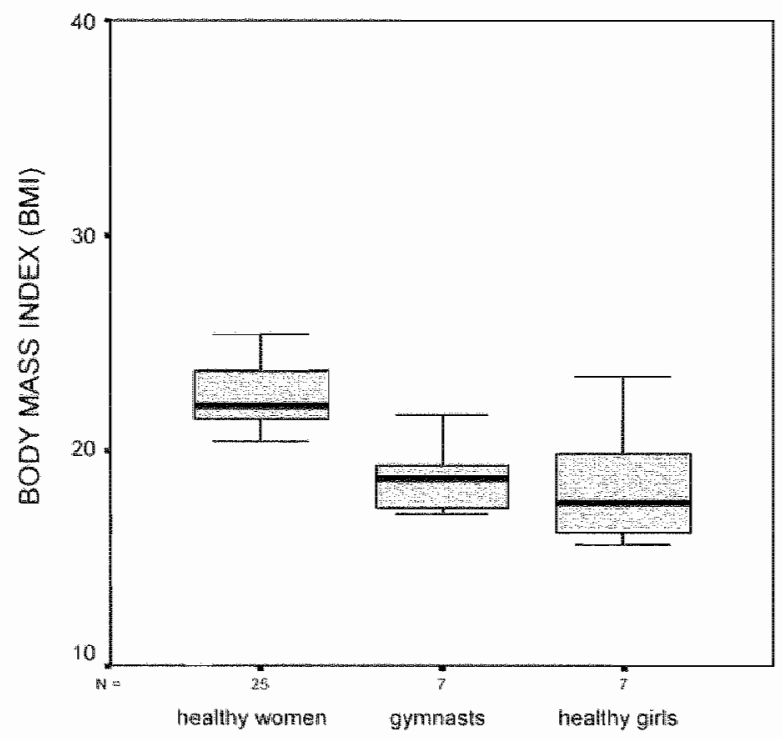

Figure 3: Body mass index (BMI) of professional gymnasts versus untrained girls and women 
As shown in Fig. 4, professional gymnasts have a higher SOT composite score (mean $=91.6, S D=1.6)$, compared to untrained girls (mean $=83.3, S D=2.8, p<0.001$ ) and women (mean $=81.0, S D=2.3, p<0.001$ ).

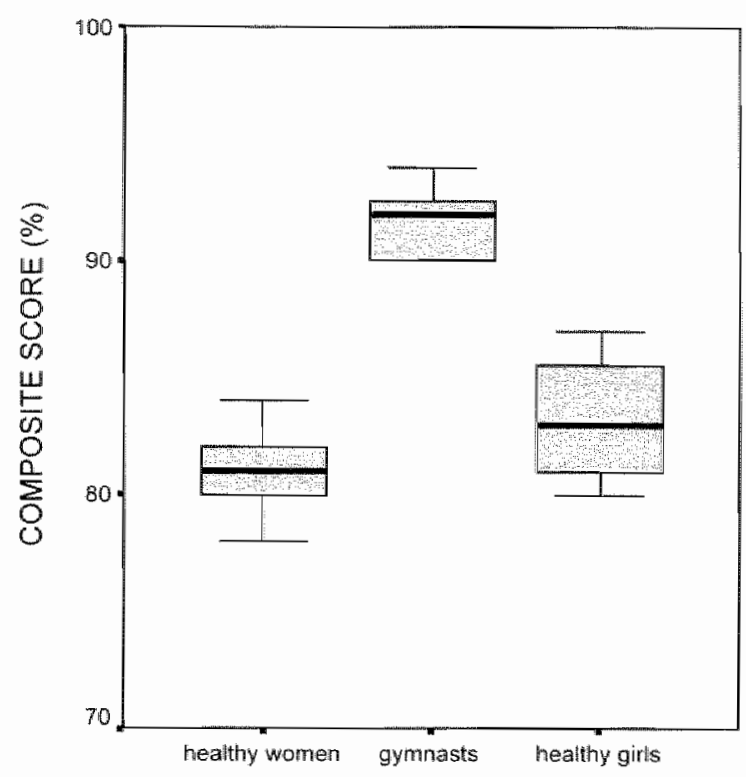

Figure 4: Composite score (\%) and standard deviation of dynamic posturograply; professional gymnasts versus healthy untrained girls and women

Median GBS gain and short-term habituation to GVS

As shown in Fig. 5 , the mean total GBS gain was significantly $(p=0.041)$ lower in the trained girls (mean $=0.47, S D=0.17)$ and also $(p=0.044)$ in the untrained girls (mean $=0.46, \mathrm{SD}=0.24$ ) compared to the adult women (mean $=0.66, \mathrm{SD}=0.22$ ). Mean total GBS gain was not significantly different between the trained and the untrained girls $(p=0.93$ ).

As shown in Fig. 6, the mean total habituation was not significantly $(p>0.20)$ different between the trained girls (mean $=8.3 \%, S D=40.7 \%$ ), the untrained girls (mean $=9.1 \%$, $\mathrm{SD}=42.6 \%$ ) and the adult women (mean $=-19.5 \%, \mathrm{SD}=53.2 \%$ ). This is probably due to the large standard deviation in all 3 groups. 


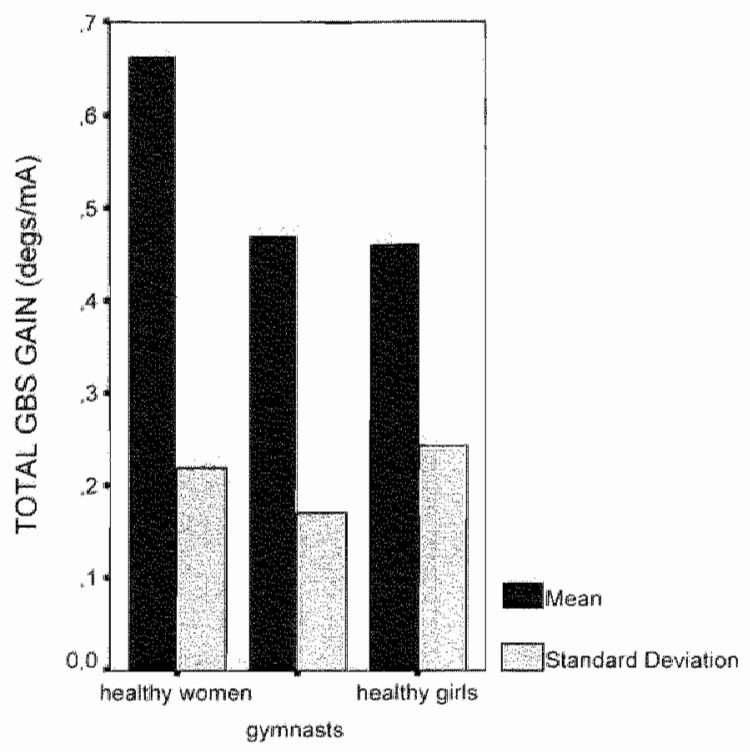

Figure 5: Mean total galvanic body sway (GBS) gain (degs/mA) and standard deviation: professional gymnasts versus healthy untrained girls and women

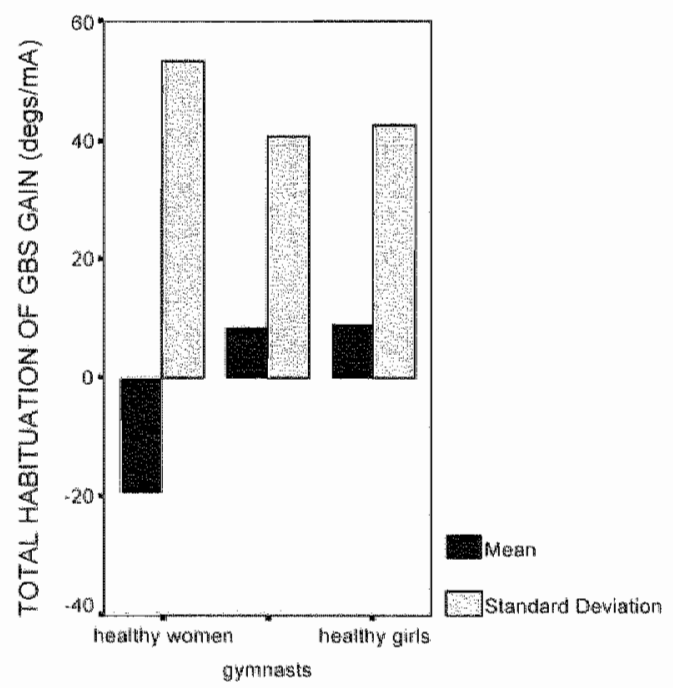

Figure 6: Mean total habituation of galvanic body sway (GBS) gain (degs/mA) and standard deviation; professional gymnasts versus healthy untrained girls and women 


\section{DISCUSSION}

As described already before $(13,14)$, professional gymnasts are significantly shorter and lighter than untrained girls or women. This suggests that intense physical training might impair growth. Also, in line with the literature, we observed that BMI in adult women is higher than in trained or untrained young girls, pointing to a higher percentage of body fat in the adults. However, in contrast to the literature $(13,14)$ we abserved no difference in BMI between trained and untrained girls. This might be explained by the fact that young physically untrained Dutch girls tend to control body weight quite strict.

It is trivial that motor control is superior in the gymnasts selected for Dutch National Junfor Gymnasts Championship than in untrained subjects, and in line with the literature ( 9 , 10). This was nicely abjectified in this study by the significant higher composite scone on the dynamic posturography test $(p<0.05)$. In this study we made an attempt to inwestigate factors that have a clear impact on the postural control abilities.

The impact of vestibular function upon motor abilities seems to differ between slow and fast body motions (15). In line with Brandt (16) we observed that patients with a recent not yet fully compensated peripheral vestibular function loss tend to fall to the affected side in stance and during siow glait, but have a normal gait when running. Also, in subjects with a centrally compensated bilateral peripheral vestibular areflexia, problems with ballance are evident when they perform walking tasks at a low speed and far less at higher speeds. We interpret these observations in the way that humans learn complex movements at a low speed limplementing them within the restraints of gravity using the labyrinths for adequate feedback. By repetition these movements can be fastened and automated in motor protocols where labyrinthine input becomes less important, as vestibulo-spinal reflexes would be too slow to correct motions. In subjects without correctly functioning labyrinths, motor learning strongly depends on proprioceptive and visual detection of the orientation of the gravity vector, which is less accurate and slower than detection by the labyrinths and results in worse motor abilities. This implies that the quality of the labyrinthine function could indeed be an important factor to account for the superior balance control in gymmasts, especially in relation to the learning and training phase of complex balance movements.

Our study showed no sigmificant differences in the sensitivity of the vestibular system to galvanic stimulation between the trained and untrained girls. In line with the observation that caloric responses between these groups are not different ether (17), this suggests that superior balance in the trained girls can not be explained by a more sensitive (better?) vestibular system per se. The observation that the untrained adult woman are more sensitive to galvanic stimulation than the young untrained girls, despite the similar motor abilities, also points to a poor correlation between vestibular sensitivity and motor abilithes. Most likely, gymnasts do not have a "better" vestibular system, or reduced VOR (apart from the well-known shorter time constant in velocity steps etc.), but have learned to use different sensory inputs better. However, a difference should be made regarding the learning process and slow balancing motions where labyrinthine function is crucial, versus motor abilities that are automatic like in acrobats and gymnasts where vestibular feedback is too slow and inadequate to correct posture and subjects use much more 
visual anticipation. We expected a faster reduction/habituation to the stimulus within the test or upon repetition in the gymnasts compared to the controls. However, this response reduction within the test was not different between the groups (unpublished data). We therefore tend to reject the hypothesis that a higher vestibular sensitivity could account for superior balance control im healthy subjects.

The other possible explanation for the superior balance control of the gymnasts, might be the better ability compared to untrained subjects to use different sensory inputs and to identify erroneous sensory input interfering with an accurate detection of the gravity vector. Better postural control of gymnasts might like Perrin (3) suggested, thus originate in the fact that learning or experience and cognition contribute to postural control by identifying threats to balance even before they happen. This will, in feed forward mode, favour the maintenance of postural control. Possibly, professional gymnasts switch faster between sensory inputs, which suggests a better central integration and identification of the really relevant sensory input. In line with this, it is reported in the literature that fighter pilots, used to aerobatics or repeated and very intense rotatory stimuli entailed by their duties, show smaller responses and faster adaptation to continuous rotatory stimulation (18).

We used repetitive galvanic stimulation as a model to mimic a sensory conflict with respect to identification of the gravity vector. This is an important factor in motor learning in gymnasts: the vestibular input is modified by the galvanic stimulation suggesting a tilt of the gravity vector, whereas the proprioceptive system detects the correct orientation relative to gravity. As soon as the body moves as a response to the simulated orientation change (GBS), proprioceptive feedback will supply an alerting response to prevent a fall leading to reduction of the GBS as a part of a learning process upon repetition. The better the subjects recognize the erroneous galvanic input, the faster habituation to the GVS accurs. However, in our study results showed no difference in mean total habituation to GVS ( $p>0.05$ ) comparing professional gymnasts versus untrained controls. It might be that in professional gymnasts proprioception is more important in balance control than other sensorv innuts like GUS Professional avmnasts thus use nast kninwlerige (arquired in sport training) during the GVS-test. This however did not affect short-term memory (developed during the test) to produce a significant difference in response decline in GVS (habituation). Fransson at al. (19) and Johansson et al. (20) already studied adaptation (or short term memory, develloped during the test) to galvanic stimulation. Fransson et al. observed adaptation to a pseudorandlom binary sequence schedule (frequency range 0.1 to $2.5 \mathrm{~Hz}$ ) within a time course of $15-20 \mathrm{sec}$ (time constant less then 7 s). Johansson et all. observed an adaptation time constant of 40-50 sec to a higher frequency stimulus (PRBS 5-10 Hz), which implies maximum adaptation within more then 120 sec ( $3 x$ time constant). The 40 -s stimulus, as used in our study, is relatively short in comparison to those used in the previously mentioned articles (about 205 and $153.6 \mathrm{~s}$ ). This does not allow an accurate determination of the time course of habituation when the time constants are in the same order of magnitude as the duration of our test. We indeed saw that the response steady decreases (unpublished data) during each sequence (40 s) down to about $70 \%$. Therefore, response decays with a time constant that can be estimated to exceed at least $40 \mathrm{~s}$ (like in the article of Johansson et al.). But allso, response 
declined upon repetition of each sequence. So apart from the fast instantaneous "adaptation" within the sequence, habituation also occurs upon repetition. Our manuscript predominantly deals with this habituation effect and not with the adaptation. Also, Vuilleme et al. (10) suggested that the efficiency of the integration process, leading to the reweighting of sensory information, can be significantly improved through a specific training. This could be evaluated by the use of long-term habituation; this was however not part of this study.

When discussing spatial orientation Merfeld et al. (21) exploits the idea that the central nervous system incorporates information about body dynamics and sensory cues to develop an internal model. Assuming that gymnastics requires (re)stabilizing body position in space immediately following the execution of acrobatic vaults involving very unusual and complex motor-perceptual situations, gymnasts might have developed a more precise internal model of their body position in space. In agreement with this "we observed in a parallel study that the abilities of the gymnasts and untrained young girls to detect the orientation of the base of support are $0.62^{\circ}$ and $0.73^{\circ}$ respectively and do not differ significantly $(p>0.05)$. So it seems that the spatial orientation abilities (identifying erroneous sensory input and the orientation of the base of support) are no major factors to account for the differences in motor control.

We suggest that the superior balance control of the gymnasts might more likely arise from the training itself and a better predisposition of them regarding motor abilities per se and not that much from differences in vestibular function or the ability to identify erroneaus sensory inputs. 


\section{REFERENCES}

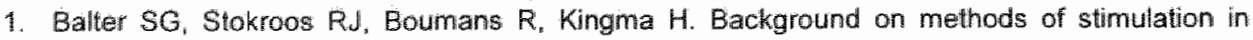
galvanic-induced body sway in young healthy adults. Acta Otolaryngol 2004; $124(3): 262-71$.

2. Balter SG, Stokroos Rd, Eterman RM, Paredis SA, Obbons J, Kingma H. Habituation to galvanic vestibular stimulation. Accepted for publication in Acta Otolaryngol.

3. Perrin $P_{*}$ Schneider $D$, Deviterne $D$, Perrot $C_{*}$ Constantinescu $L$. Training improves the adaptation to changing visual conditions in maintaining human posture control in a test of sinusoidal oscillation of the support. Neuroscience Letters 1998:225:155-158.

4. Cencianini $M$, Peterka $R$, Horak $F$. Habituation to galvanic vestibular stimulation depends on sensory reweighting. d. Vest. Res. 2001/2002;11(3-5):288.

5. Hlavacka $F$, Mergner $T$, Schweigart $G$. Interaction of vestibular and proprioceptive inputs for human self-motion perception. Neurosc. Lett. 1992;138:161-164.

6. Perrin P, Béné MC, Perrin C, Durupt D. Ankle trauma significantly impairs posture control: a study in basketball players and controls. Int J. Sports Med. 1997;18:387-392

7. Vidal PP, Berthoz A, Millavoye M. Difference between eye closure and visual stabilization in the control of posture in man. Aviat. Space Environ. Med. 1982;53:166-178.

8. Perrin P. Deviterne D, Hugel F, Perrot C. Judo, better than dance, develops sensorimotor adaptabilities inwolved in balance control. Gait and Posture 2001:15:187-194.

9. Vuillerme $N$, Danion $F$, Marin L, Boyadjian $A_{4}$ Prieur JM, Weise I, et all. The effect of expertise in gymnastics on postural control. Neurosci Lett 2001,303(2):83-6.

10. Vuillerme $N$, Teasdale $N$, Nougier $V$. The effect of expertise in gymnastics on proprioceptive sensory integration in human subjects. Neuroscience Letters 2001;311:73-76.

11. Nashner LM, Peters JF. Dynamic posturography in the diagnosis and management of dizziness and balance disorders. Neurol Clin 1990;8(2):331-49.

12. Winter DA. Biomechanics of human movement. New York: Wiley \&Sons; 1979.

13. Weimann E. Gender-related differences in elite gymnasts: the female athlete triad. J Appl Physiol 2002:92(5):2146-52.

14. Weimann $E$, Blum WF, Witzel $C$, Schwidergall $S_{\text {n }}$ Bohles HJ. Hypoleptinemia in female and male elite gymnasts. European Journal of Clinical investigation 1999;29:853-860.

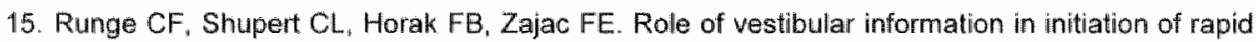
postural responses. Exp Brain Res 1998;122(4):403-12.

16. Brandt T. Vertigo: its multisensory syndromes. In: Vertigo: its multisensory syndromes. London: Springer-Verlag; 1991 . p. 483-496.

17. Shorin GA. [Vestibular and optokinetic reflexes in sportsmen]. Vestn Otorinolaringol 1983(2):1821.

18. Aschan G. Response to rotatory stimull in fighter pillots. Acta Oto-Laryngol. Suppl. 1954:116:2431.

19. Fransson PA. Hafstrom A, Karlberg M, Magnusson M, Tjader A, Johansson R. Postural control adaptation during galvanic vestibular and vibratory proprioceptive stimulation. IEEE Trans Biomed Eng 2003;50(12):1310-9. 
20. Johansson R, Magnusson M, Fransson PA. Gahanic vestibular stimulation for analysis of postural adaptation and stability. IEEE Trans Biomed Eng 1995;42(3):282.92.

21. Merfeld DM, Zupan L, Peterka RJ. Humans use internal models to estimate gravity and linear acceleration. Nature $1999 ; 398: 615-618$. 



\section{Chapter 7}

\section{Galvanic-induced body sway in vestibular schwannoma patients: evidence for stimulation of the central vestibular system}




\section{ABSTRACT}

The aim of this sudy was to investigate the various possible sites of excitation by galvanic stimulation by comparing the galvanicinduced body sway (GBS) in vestibular schwanmoma (VS) patients with GBS in healthy subjects. In line with the literature $(1,2)$ we included in this paper our retrospective clinical data that indicated that GBS is generally normal in patients with a caloric hyporeflexia lacking any signs of a retro-labyrinthine disorders. We observed also that therapeutical ablation of the peripheral vestibular function by gentamicine affects the caloric but not the galvanic excitability. These observations suggest a retro-labyrinthine excitation-site. This study further focussed on the excitability of this retro-labyrinthine conducting-course composed by the vestibular nerve. including Scarpa's ganglion. followed by the vestibular nuclei and more afferent central vestibular areas. In VS-patients the anatomy of the vestibular nerve is disturbed, and even more after vestibular neurectomy, which could make it possible to differentiate between the vestibular nerve and the vestibular nuclei as sites for retro-labyrinthine galvanic excitation.

This was a prospective experimental study conducted in a tertiary referral centre. In our previous study (3) we developed a standardized procedure for a reproducible quantification of galvanic-induced body sway (GBS) using a monaural continuous 1-cosinusoidal stimulus $(0.5 \mathrm{~Hz}-2 \mathrm{~mA})$. In this study $23 \mathrm{VS}$-patients were tested before and $12 \mathrm{VS}$ patients also after surgical intervention (extirpation of tumour with concomitant vestibular neurectomy) versus 47 healthy subjects. Results showed no significant differences in mean total GBS gain between VS-patients and healthy subjects ( $p>0.05$ ) before surgical intervention. After vestibular neurectomy a significant difference in the mean total GBS gain was observed, but GBS was still present after surgery. The latter proved that GVS could excite the central vestibular system even when conduction via the vestibular nerve was hampered.

Key wards: galvanic vestibular stimulation, galvanic-induced body sway, vestibular schwannoma, central vestibular system

\section{INTRODUCTION}

It is generally assumed that in galvanic vestibular stimulation (GVS), or anodal and cathodal polarising currents applied to the mastoids, the peripheral receptors are bypassed and the excitation state of Scarpa's ganglion is directly modified $(2,4,5)$. The actual conduction course of GVS, however, remains uncertain. It is possible that the electrical current is transmitted through the bony tissue surrounding the peripheral vestibular system exciting the labyrinthine hair cells, the vestibular nerve including Scarpa's ganglion, as well as exciting the central vestibular system (vestibular nuclei, cerebellum, cortical areas). Literature (1) indicates that GBS is generally normal in patients with a caloric hyporeflexia lacking any signs of a retro-labyrinthine disorders, suggesting a retrolabyrinthine excitation-site. A study conducted by Hulshof et al. (6) showed that in most 
Cases of vestibular schwannoma (VS), the peripheral part of the vestibular system is disturbed. A study of GVS in VS-patients is therefore interesting as it could show the impact of a disturbed peripheral vestibular system on galvanic-induced body sway (GBS).

The VS, previously called acoustic neuroma and neurinoma, is the most common cerebello-pontine angle tumour and usually arises in the internal auditory camal (7). Currently, the golden standard in assessing patients with a possible VS is GD-enhanced magnetic resonance imaging (MRI) $(8,9)$. Until now no general applied standardized procedures to discriminate disorders of the labyrinth or vestibular nerve have been established (10). The majority of VS-patients present with an asymmetric hearing loss. Brainstem evoked response audiometry (BERA) is the most sensitive auditory test available to date; sensitivity values in literature varying from $63 \%-95 \%(11-13)$. Of the $5 \%$ who do not present with asymmetric hearing loss, $30 \%$ are said to present with disequilibria or vertigo (14). Collins et al. (15) studied postural stability of 51 pre-operative VS-patients assessed by sway magnetometry; $44 \%$ of patients have abnormal sway path lengths, which increases to $49 \%$ with their eyes closed.

According to literature $(16,17)$, most VS originate from the inferior vestibular nerve (IVN), followed by the superior vestibular nerve (SVN) and finally the cochlear and facial nerve in a smaller number of cases. VS is a benign growth of the eight nerve sheath, an over-proliferation of schwann cells, usually originating lateral to the glial-schwannian junction of the nerve (18). It is a slowly growing neoplasm and insidiously progressive in its development (19). Hypothesizing that the vestibular nerve is a necessary conducting course in GVS, VS-patients should show an affected GBS because of a reduced conduction capacity of the electrical current through the growing neoplasm along the vestibular nerve.

Dix and Hallpike and Coats (20-23) tried to quantify vestibular nerve function by study of the GVS, but were not successful due to the large variability of the responses. In our opinion vestibular nerve function cannot be quantified by GVS. In our study evidence for additional direct stimullation of the central vestibular system is given, because GES could be elicited in VS-patients even after vestibular neurectomy.

\section{MATERIALS AND METHODS}

\section{Subjects}

Group 1: Twenty-three patients with a unilateral vestibular schwannoma (VS) (9 males, 14 females; mean age 61.7 years, range 39-81 years) Twelve VS-patients were also tested post-operative

Group 2: Forty-seven healthy subjects

(27 males, 20 females, mean age 26.6 years, range 18.54 years) 
The twelwe (post-operative) VS-patients were subdivided according to the New Hannover classification for tumour-extension (24):

T1: purely intrameatal

T2: intra- and extrameatal

T3a: fithing the cerebello-pontine cistern

T3b: reaching the brainstem

T4a: compressing the brainstem

T5: severely compressing the brainstem and compressing the fourth ventricle

T1-T2 were considered small tumours $(n=7)$; T3a-T5 were considered large tumours $(n=5)$.

All patients with a VS ( $n=23)$ were diagnased by GD-enhanced magnetic resonance irnaging (MRI). In eleven patients the WS was situated on the left side, in twelve patients the VS was situated on the right side.

In the healthy (control) group ( $n=47)$, subjects with a history of vestibular, musculoskeletal or neurological complaints were excluded. All subjects did not use any medication possibly affecting the vestibular or musculoskeletal system. Alcohol consumption was prohibited 24 hours prior to testing.

\section{Materials}

A computer-controlled stimulator, built in our department and meeting the appropriate safety regulations (IEC 601.1), generated the type of galvanic stimulus described below. The stimulator is provided with a feedback mechanism so that an identical galvanic stimulus can be applied to every subject tested, irrespective of the electrical conductivity of skin and temporal bone. The electrodes measure $50 \times 35 \mathrm{~mm}^{2}$ and are composed of silicon rubber, mixed with conducting carbon particles (CEFAR ${ }^{\mathrm{TM}}$ Medical Products, Lund, Sweden). The electrodes were attached to the retro-auricular skin with electro conductive adhesive gel (Tac Gelm). Movements of the centre of pressure (COP) were measured using a force platform $\left(42 \times 35 \mathrm{~cm}^{2}\right.$; Jaeger-Toennies GmbH, Wurzburg. Germany) equipped with four transducers, one at each cormers. Data-acquisition ( $50 \mathrm{~Hz}$ sampling rate) and analysis were performed using a T-Post-Nystagliner computer system (Jaeger-Toennies GmbH).

\section{Procedure}

All VS patients first underwent a caloric test (right and left ear were irrigated for 30 sec with $300 \mathrm{ml}$ of water of $44^{\circ} \mathrm{C}$ and $30^{\circ} \mathrm{C}$ ) and a pure tone audiogram. Next, the GVS-test was performed.

Prior to testing the retro-auricular skin was cleaned with petroleummether and Tac Gelrm. applied onto three electrodes. The gel was allowed to dry for five min to improve adhesion to the skin. We placed two electrodes at the mastoid, one behind each ear. A third electrode was placed on the neck at the $c 7$ vertebra (3). 
In case of monaural stimulation the retro-auricular electrodes were used as positive electhodes and the neck electrode as a negative electrode. The electrodes were fixed with adhesive tape (Mefix(B) ). In order to optimize retro-auricular stabilization of the electrodes and reduce auditory spatial orientation the subject wore a headphone. During each test, lights in the test-cabin were dimmed and the subject's eyes closed to prevent any visual orientation. Each subject was instructed to stand upright with bare closed feet (inter-feet distance $0 \mathrm{~cm}$ ) on the force platform and with the arms crossed in front of the body. The test cabin was provided with a frame surrounding, which did not touch the subject, to prevent a fall in case of severe imbalance.

In each test the following 8 test sequences were completed: First the natural body sway of each subject was measured without any stimulation for $40 \mathrm{~s}$ (zero-reference). Next, all subjects received a prestimulus consisting of a 40 -s continuous sinusoidal $0.5-\mathrm{Hz}$ stimulation of $1 \mathrm{~mA}$. Finally, the subjects were stimulated on the left and right sides alternately 3 times using a 40-s continuous 1-cosinusoidal $0.5-\mathrm{Hz}$ stimulus of $2 \mathrm{~mA}$.

\section{Data analysis}

The mean caloric value (in degrees) was calculated for the affected and unaffected sidie as follows:

$[($ caloric value warm $)+($ caloric value cold $)] / 2$

The asymmetry in caloric values (\%) was calculated in analogy with the Jongkees formula as follows:

$$
100 * \frac{[(\text { caloric value unaffected side })-(\text { caloric value affected side })]}{[(\text { caloric value unaffected side })+(\text { caloric value affected side })]}
$$

The mean hearing loss (in decibel) was calculated on the affected and unaffected side as follows:

thearing loss at $(250 \mathrm{~Hz}+500 \mathrm{~Hz}+1 \mathrm{kHz}+2 \mathrm{kHz}+3 \mathrm{kHz}+4 \mathrm{kHz}+6 \mathrm{kHz}+8 \mathrm{kHz}) / 8$

The asymmetry in mean hearing loss (in decibel) was calculated as follows:

(hearing loss unaffected side) - (hearing loss affected side)

The lateral body sway was expressed in degrees per mA. The displacement of the (COP) was normalized for body length as follows:

$$
\text { Body sway (degrees })=\operatorname{cotan}(\mathrm{COP} /(0.56 \times \text { body length }))
$$

Here we assume that the centre of body mass is positioned on average at a point $56 \%$ along the length of the body (25). The frequency spectrum of the time series is calculated by fast Fourier transform (FFT) using a Hamming filter and a 2048-point window. The frequency spectrum acquired with stimulation is then corrected for the background noise and natural body sway by subtracting the frequency spectrum acquired without stimulation. Subsequently, the average amplitude of the difference spectrum is calculated at the stimulus frequency (seven classes wide of the discrete Fourier spectrum) 
and taken as the typical response and nomalized relative to the stimulus amplitude (per mA. .

The test outcome in the VS-group was expressed as the mean total gain of the lateral galvanic-induced body sway (GBS gain) of the affected (VS) side or the unaffected side of the three test sequences in degrees per $m A$.

$$
\begin{gathered}
\text { mean total glain (affected) = } \\
\text { (GAINaffected1+GAINaffected2+GAlNaffected3)/3 } \\
\text { mean total gain (unaffected) }= \\
\text { (GAlNunaffected1+GAINunaffected2+GAlNunaffected3) / } 3
\end{gathered}
$$

The test outcome in the healthy control-group was expressed as the mean total gain of the lateral GBS gain of the three ipsilateral test sequences in degrees per mA:

$$
\begin{gathered}
\text { mean total gain (Left) }=(\text { GAINL1+GAINL2+GAINL3)/3 } \\
\text { mean total gain }(\text { Right })=(\text { GAINR } 1+\text { GAINR2+GAINR3)/3 }
\end{gathered}
$$

The asymmetry in galvanic outcome $(\%)$ was calculated as follows:

$$
100 * \frac{\text { [Mean total gain (unaffected) - mean total gain (affected)] }}{\text { [Mean total gain (unaffected) + mean total gain (affected)] }}
$$

Statistical analysis (Mann-Whitney U-Test, Levene's Test for Equality of Variances, Independent Samples Test and Nonparametic correlations (Pearson, Kendall"s tau_b, Spearman) was performed using SPSS software (version 11.0; SPSS ImC., Cary, NC).

\section{RESULTS}

\section{Asymmetry in caloric values in VS-patients}

The caloric values of the affected side (mean $=11.4$ degrees, $S D=10.3$ degrees) showed a significant $(p<0.001)$ lower value compared to the unaffected side (mean $=25.0$ degrees, $\mathrm{SD}=9.5$ degrees).

The mean asymmetry in caloric values (unillateral weakness) was $46.9 \%$ ( $S D=30.2 \%$ ).

\section{Asymmetry in hearing in VS-patients}

The hearing loss of the affected side (mean $=67 \mathrm{~dB}, S D=27 \mathrm{~dB}$ ) showed a significant $(p<0.001)$ lower value compared to the unaffected side (mean $=27 \mathrm{~dB}, S \mathrm{~S}=18 \mathrm{~dB}$ ). The mean asymmetry of hearing loss was $40 \mathrm{~dB}(\mathrm{SD}=27 \mathrm{~dB})$. 
In healthy subjects, no significant $(p>0.05)$ differences were observed between the mean total GBS gain upon left and right stimulation.

No significant $(p>0.05)$ differences were observed between the mean total GBS gain obtained by stimulation of the unaffected side in VS-patients $(0.69$ degrees/mA $)$ and healthy subjects $(0.64$ degrees/mA) either (Fig 1$)$.

No significant differences were observed $(p>0.05)$ comparing the mean total GBS gain (affected side) of VS-patients $(0.50$ degrees $/ \mathrm{mA})$ versus healthy subjects (0.64 degrees/mA) pre-operative (Fig. 2).

Only after surgical intervention (extirpation of tumour with concomitant vestibular neurectomy) significant differences $(p<0.001)$ of the mean total GBS gain on the affected side in VS-patients $(0.18$ degrees $/ \mathrm{mA})$ versus the unaffected side $(0.54$ degrees $/ \mathrm{mA})$, and versus healthy controls ( 0.64 degrees $/ \mathrm{mA}$ ) were observed (Fig. 3a and $3 \mathrm{~b}$ ).

Post-operatively, the mean total GBS gain of the unaffected side in VS-patients $(0.54$ degrees $/ \mathrm{mA})$ showed no significant differences $(p=0.25)$ with healthy controls $(0.64$ degrees $/ \mathrm{mA}$ ).

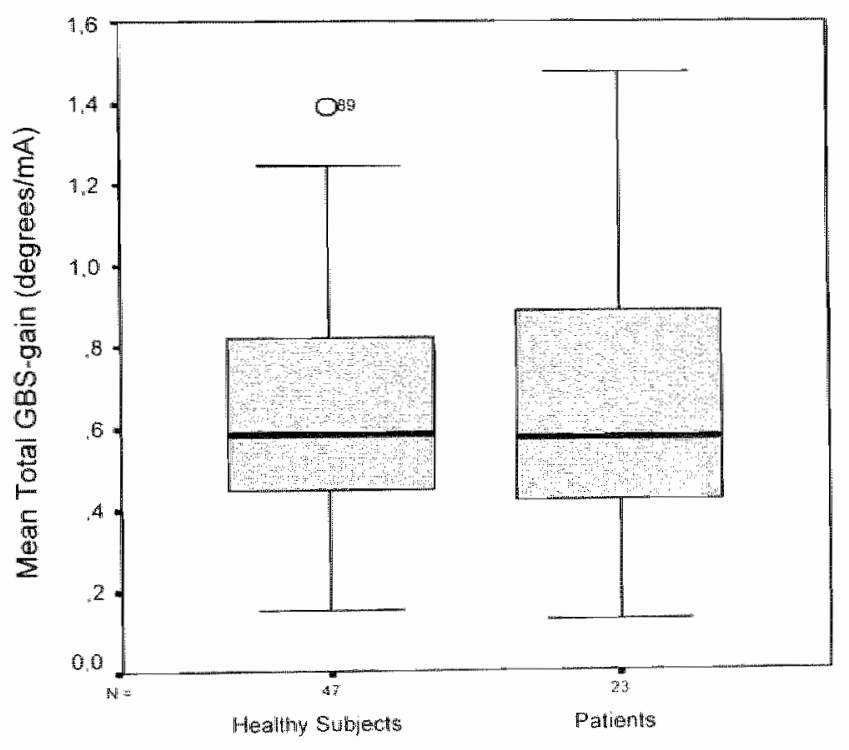

Figure 1: Boxplots of mean total GBS gain (degrees/mA) of the healthy subjects versus VS-patients before operative treatment on the umaffected side 


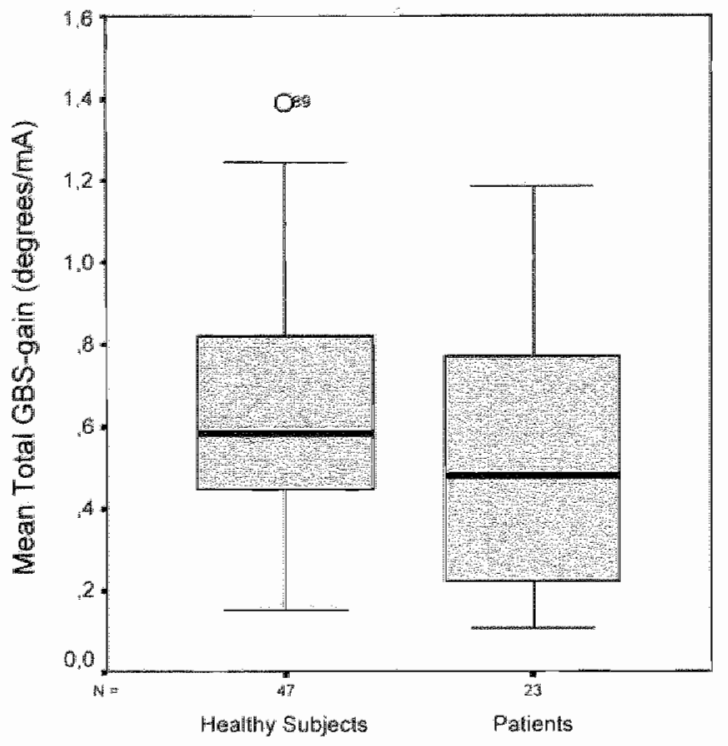

Figure 2: Boxplots of mean total GBS gain (degrees/mA) of the healthy subjects versus VSupatients before operative treatment on the affected side

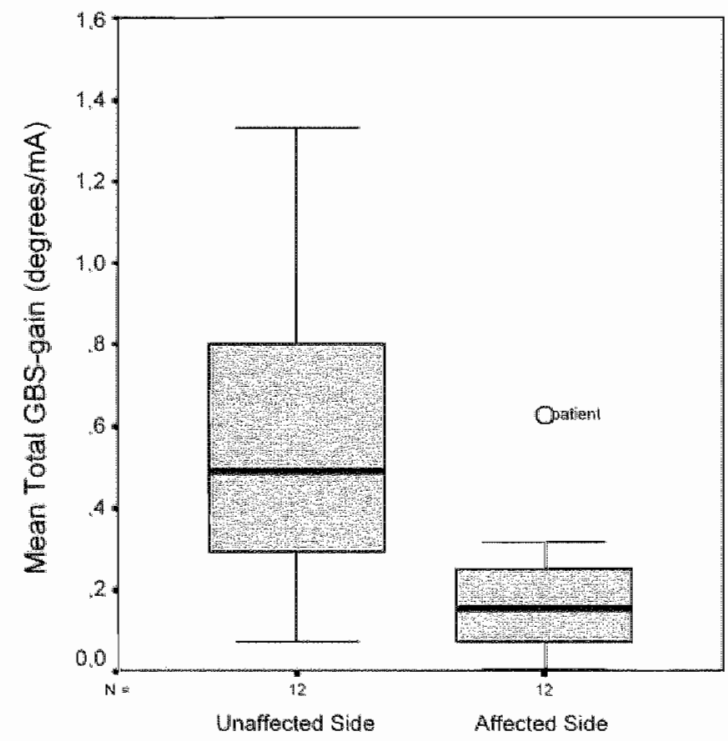

Figure 3a: Boxplots of mean total GBS gain (dlegrees/mA) of the VS-patients after operative treatment; unaffected side versus affected side 


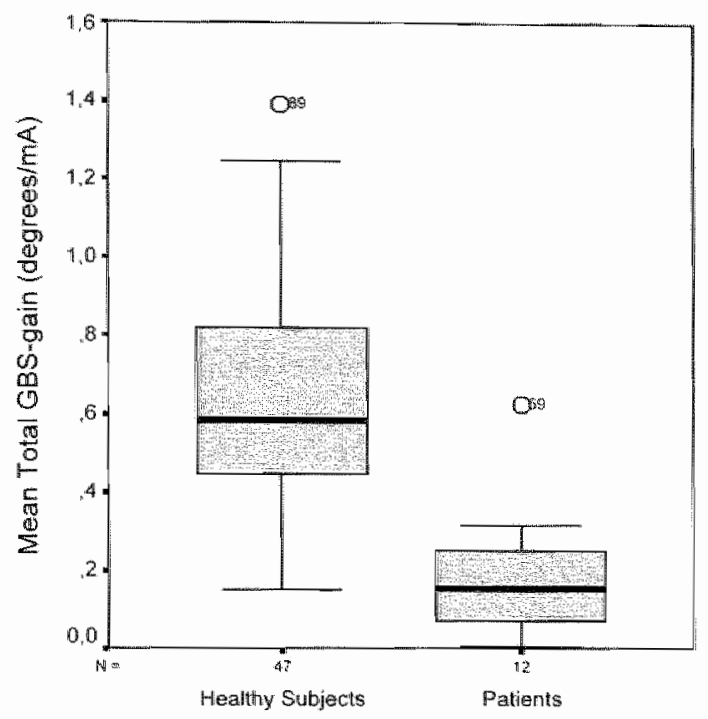

Figure 3b: Boxplots of mean total GBS gain (degrees/mA) of the healthy subjects versus VS-patients after operative treatment on the affected side

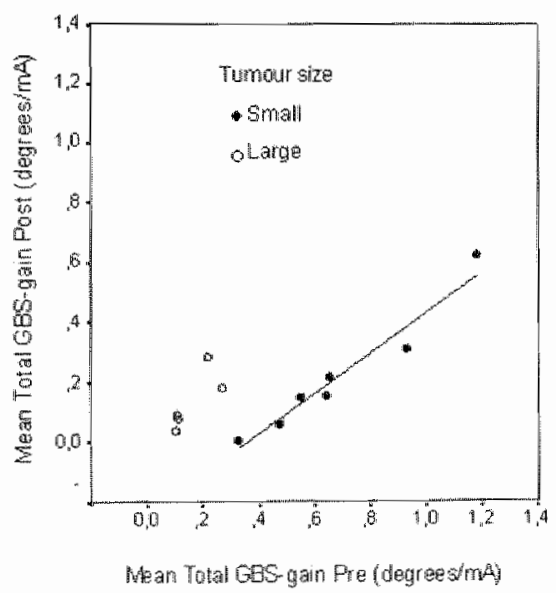

Figure 4: The correlation of the mean total GBS gain (in degrees/mA) in VS-patients with small versus large tumours on the afffected side pre-operative and post-operative (correlation $=0.38 ; p=0.23$ ) 
$K$ - Means Cluster Analysis showed that the post-operatively tested VS-patients ( $n=12$ ) could be subdivided into two different groups according to tumour-size. Comparing the small $(n=7)$ versus large $(n=5)$ tumours, hearing, caloric function and galvanic excitability were all significantly $(p<0.05)$ lower in the five patients with large tumours.

GBS gain was relatively small and not significantly reduced after neurectomy in the five patients with large tumours (Fig. 4, open symbols). The mean total GBS gain of VSpatients with small tumours decreased after surgery: pre- and postoperative mean total GBS gains were correlated (correlation $=0.95 ; p<0.001$. Fig. 4, closed symbols). Regression analysis showed a linear relation expressed by:

$$
\text { GBS gain POST }=-0.25+0.69{ }^{*} \text { GBS gain PRE }
$$

Correlation between hearing loss, caloric values and mean total GBS gain in VS-patients No correlation was observed between hearing loss, caloric excitability and mean total GBS gains on the affected side in VS-patients.

\section{DISCUSSION}

Regardless the origin of the cerebello-pontine angle tumour, the presence of the tumour mass compresses the facial, acoustic and both vestibular nerves (26). Lapsiwala et al. (27) objectified that, in VS-patients, tumour growth into the internal auditory canal results in elevation of intra-canalicular pressure that might play a role in hearing loss.

In our study hearing loss of the affected side showed indeed a significant $(p<0.001)$ lower value compared to the unaffected side. The mean asymmetry in hearing loss was $40 \mathrm{~dB}(\mathrm{SD}=27 \mathrm{~dB})$.

The previously mentioned study (27) also leads to the suspicion that both SVN and IVN will show dysfunction. As indicated before, most VS originate from the IVN, followed by the SVN. Caloric irrigation mainly stimulates the lateral semicircular canal (28), and thus the SVN. This might imply that caloric excitability would be normal in most VS-patients. In contrast, we observed a significant $(p<0.001)$ reduced caloric excitability in the VSpatient population, with a pronounced function loss in some patients and no loss in others. This is best explained by assuming that VS primary affects the IVN function and secondary by intra-canalicular pressure the SVN function (may be larger tumours).

Serizawa and Tokita $(29,30)$ suggested that GVS mainly indicates the reaction of the statolithic system and therefore stimulates both SVN (utriculus) and IVN (sacculus). This suggests that GBS is expected to be more affected than the caloric excitability in VSpatients if the nerve is the primary site of excitation. However, our study showed no significant differences comparing the mean total GBS gain of VS-patients versus healthy subjects. This suggests that the galvanic stimulus can bypass the disturbed nerve to excite more centrally located vestibular structures directly. This hypothesis was further supported by the observation that after surgery (including neurectomy of SVN and IVN) 
still a GBS exists. The significant difference $(p<0.001)$ of the mean total GBS gain (affected side) in VS-patients after surgery versus healthy controls indicates that stimulation of the nerve also significantly contributes to the GBS. To summarize we suggest that the GBS arises from stimulation of the vestibular nerve (IVN and SVN) and more centrally located vestibular structures (vestibular nuclei, cortical areas). In agreement with Magnussom et al. (31) we observed that local gentamicin therapy significantly reduced caloric excitability in patients with active unilateral Meniere's disease, which points to a (partial) labyrinthine ablation. In the same patients we also observed that GBS was nol affected by this treatment (unpublished resuits). which suggests that the GBS does not arise from labyrinthine excitation. In line with this and similar to Tsutsumi ef al. (1), we found no correlation between the GBS and the caloric excitability in VS-patients, which fits the hypothesis that galvanic stimulation - in contrast to caloric stimulation - is still effective in case of a deficit of the vestibular nerve and/or labyrinth.

Fig. 4 shows that in the patients with large tumours excitability is not affecled by surgery. This together with the observation that the excitability pre-operative is already relatively small, suggests that the remaining excitability (ranging from 0.06 till $0.35 \operatorname{degs} / \mathrm{mA}$ ) arises from central excitation only (root entry zone of the vestibular nuclei?). Remarkably two patients with small tumours and a low excitability close to the shown excitability in patients with large tumours, show a $100 \%$ reduction of the response. Apparently no excitation of the central vestibular system occurs in these two patients. Regarding responses in all seven patients with small tumours post-operative excitability increases linear with pre-operative excitability. This curve indicates that central excitation contributes from $0 \%$ to $50 \%$ of the response in patients with small tumours. So, the picture is complex and the contribution of central excitation to the galvanic response depends on several yet unknown factors. In any case, our data support the hypothesis that central excitation occurs in many patients butt not in all.

We can only speculate about the explanation. The poor central excitation in the large tumours might be explained by dysfunction in conduction capacity of the raot entry zone by compression. A major problem is explaining the lack of central excitation in some of the patients with small tumours. We confirmed this observation in our current clinical practice. We seem to be left with the hypothesis that a major factor of the large interindividual variability of the galvanic responses, together with the variable contribution of central excitation, may arise from basic differences in the conduction properties of the scull and surrounding tissues. So despite the observation that the GBS to some extent reflects the function of the peripheral vestibular nerve, the variable contribution of the central excitation hampers a simple clinical interpretation of the GBS. In conclusion, we observe that excitability is a sign of functionality of the peripheral and/or central vestibular system. However, a lack of excitability points to a severe function loss of the vestibular nerve, but does not reflect the absence of central vestibular functionality. Pfaltz et al. (32) suggested already many years ago that low currents only reach the peripheral vestibular system, whereas higher currents additionally stimulate central parts. This would imply that the $2 \mathrm{~mA}$-stimulus, used in this study, might be too high to allow discrimination. 


\section{CONCLUSION}

In contrast to earlier statements in literature (33-37) we conclude with stating that evaluation of GBS should not be seen as a clinical tool in diagnosing VS. For the early clinical diagnosis of VS a complete battery of vestibular tests (including GVS) is essential in combination with audiometric (BERA), neurologic and radiologic analysis.

Our work showed that GBS could still be evoked after vestibular neurectomy. This means that the primary side of excitation is not, as thought so far (2), exclusively the peripheral neurones in the vicinity of the labyrinth (including Scarpa's ganglion). Instead, our work proved that in most (but not all) patients galvanic stimulation additionally excites the central vestibular system. 


\section{REFERENCES}

1. Tsutsumi $T$, Komatsuzaki $A$. An adequate parameter evaluating the galvanic body sway test: comparison with the caloric test in patients with vestibular schwannomas. The Journal of Laryngology and otology 1999;113:418-121.

2. Courjon JH, W. P. D.W. S. Vestibular nerve and nuclei unit responses and eve movement responses to repetitive galvanic stimulation in the llabyrinth in the rat. Exp Brain Res $1987 ; 66: 41-8$.

3. Balter SG, Stokroos RJ, Boumans R, Kingma H. Background on methods of stimulation in galvanic-induced body sway in young healthy aduits. Acta Otolaryngol 2004:124(3):262-71.

4. Lowenstein $\mathrm{OJ}$. The effect of galvanic polarization on the impulse discharge from sense endings in the isolated labyrinth of the thornback ray (raja claviata). Physiol 1955;127:104-17.

5. Goldberg J, Smith $C$. TFernandez $C$. Relation between dicharge regularity and responses to externally applied galvanic currents in vestibular nerve afferents of the squirrel monkey. J Neurophysiol 1984;51:1236-56.

6. Hulshof JH, Hilders CG, Baarsma EA. Vestibular inwestigations in acoustic neuroma. Acta Otolaryngol 1989;108(1-2):38-44.

7. Moffat DA, Golledge J Baguley DM. Hardy DG. Clinical correlates of acoustic neuroma morphology. J laryngol Otol 1993;107:290-4.

8. Brackmann DE. Current status of $A B R$ audiometry in acoustic neuroma diagnosis. Arch Otolaryngol Haed Neck Surg 1999;125:235.

9. Doyle KJ. Is there still a role in auditory brain stem response audiometry in the diagnosis of acoustic neuroma? Arch Otolaryngol Haed Neck Surg 1999;125 (2):232-4.

10. Cass SP, Redfern MS, Furman JM, DiPasquale JJ. Galvanic -Induced posturial movements as a test of vestibular function in humans. Laryngoscope 1996;106:423-430.

11. Swan IRC. Diagnostic vetting of individuals with asymmetic sensorineural hearing impairments. The Journal of Lanyngology and otology 1989;103:823-826.

12. Gosepath K, Maurer J, Mann W. Diagnostik intrameatal gelegener akustikusneurinome-die rolle akustisch evozienter himstampotentiale und anderer otoneurologischer untersuchungsverfahren. Laryngo-Rhino-Otol. 1995; 74:728-732

13. Ruckenstein MJ, Cueva RA, Morrison DH. Press G. A prospective study of ABR and MRI in the screening for westibular schwannomas. Am 』Otol 1996;17(2):317-20.

14. Lustig LR, Rifkin S, Jackler RK. Acoustic neuromas presenting with normal or symmetrical hearing: factors associated with diagnosis and outcome. Am J Otol 1998;19:212-218.

15. Collins MM, Johnson IJM, Clifford E, Birchall JP, O'Donoghue GM. Pastural stability of preoperative acoustic neuroma patients assessed by sway magnetometry: are they unsteady? The Laryngascope 2003:113:640-642.

16. Komatsuzaki A, Tsunoda A. Nerve origin of the acoustic neuroma. The Journal of Laryngology and otology 2001:115:376-379.

17. Jackler RK, Brackmann DE. Neurotology. St. Louis: Mostby; 1994.

18. Xenellis JE, Linthicum FHi. On the myth of the glial/schwann junction (obersteiner-redlich zone) origin of vestibular nerve schwannamas. Otology \&Neurotology $2003,24(1): 1$. 
19. Shiffman F, Dancer J, Rothballer A.B, Berret $A$, Baum $S$. The diagnosis and evaluation of acoustic neuromas. Otolaryngol Clin North Am 1973;6:189-228.

20. Coats AC. Limit of normal of the galvanic body-sway test. Ann. Otol. 1972;81:410-416.

21. Coats $A C$. Effect of varying stimulus parameters on the galvanic body-sway response. Ann. Otol. 1973;82:96-102.

22. Coats AC. The variability of the galwanic body-sway lest. Ann. Otol. 1973;82:333-339.

23. Dix MR: Hallpike CS. The pathology, symptomatology and diagnosis of certain common disarders of the vestibular system. Ann. Otol. Rhinol. Laryngol. 1952;61:988-1016.

24. Cerullo Lu, Grutsch JF, Heiferman $K_{1}$ Osterdock $R$. The preservation of hearing and facial nerve function in a consecutiwe series of Lnilateral vestibular nerve schwannnoma surgical patients (acoustic neuroma). Surg Neural 1993:39(6):485-93.

25. Winter DA. Biomechanics of human movement New York: Willey \&Sons; 1979.

26. Ho SY. Kveton JF. Acoustic neuroma. Assessment and management. Otolaryngol Clin North Am 2002;35(2):393-404, viij.

27. Lapsiwala SB, Pyle GM, Kaemmerle AW, Sasse FJ, Badie B. Correlation between auditory function and internal auditory canal pressure in patients with vestibular schwannomas. J Neurosurg 2002;96:872-876

28. Aw ST, Haslwanter T, Fetter M, Heimberger J, Todd MJ. Comtrilbution of the vertical semicircular canals to the caloric mystagmus. Acta Otolaryngol 1998; 118(5):618-27.

29. Serizawa Y, Nozue M, Yokayama $T$, Uemura K. Galvanic body sway in the cases of inner ear lesion, vestibular nerve lesion and Scarpa's ganglion lesion (in Japanese). Equilibrium Research 1987;46:142-146.

30. Tokita T. The value of galvanic test in the topographical diagnosis of vestibular disorders with reference to vestibular neuronitis (in Japanese). Vestibular Ganglion Cell and Vestibular Neuronitis (Sekitani, T., ed.) Kodama Press. 1988:111-121.

31. Magnusson M, Padoan S. Delayed onset of ototoxic effects of gentamicin in treatment of Meniere's disease. Rationale for extremely low dose therapy. Acta Otolaryngol $1991 ; 111(4): 671-6$.

32. Pfaltz $\mathrm{CR}$. The diagnostic importance of the galvanic test in atoneurology. Pract Otorhinolaryngol (Basel) 1969;31(4):193-203.

33. Watanabe $Y$, Mizukoshi $K$, Ohi $H$, Yasuda $K$, Ohasi $N$ "Kobayashi $H$. Retro-labyrinthine disorders detected by galvanic body sway response in routine equilibrium examinations. Acta Oto-Laryngol. Suppl 1989,468:343-348.

34. Brackmann T, Ranft U. Zum stellenwert der galvanischen gleichgewichtsprüfung. HNO 1989;37:174-178.

35. Schneider $E$, Glasauer $S$, Dieterich $M$. Central processing of human ocular torsion analyzed by galvanic vestibular stimulation. Neuroreport 2000;11(7):1559-63.

36. Praltz CR. [Proceedings: Studies on the diagnostic significance of the galvanic test in acoustic neurinoma]. Arch Klin Exp Ohren Nasen Kehlkopfheilkd 1973;205(2):130-4.

37. Pfaltz CR, Koike Y. Galvanic test in central vestibular lesions. Acta Otolaryngol 1968;65(1):1618. 


\section{Chapter 8}

\section{Summary and general discussion}




\section{SUMMARY}

Our study is designed to investigate galvanic-induced body sway (GBS) and to develop a standardized procedure for a reproducible quantification of GBS. A basic introduction of the relevant literature, the aim of this study and the contents of this thesis are given in the intraduction (chapter 1).

Chapter 2 describes the experimental set-up and the pilot study, in which the galvanic vestibular stimulation (GVS) method that results in the best reproducible responses is defined. A monaural continuous 1 -cosinusoidal current of $0.5 \mathrm{~Hz}$ and $2 \mathrm{~mA}$ gives the best reproducible responses and is used for further testing in our normative study. Binaural prestimulation reduces short-term habituation. Despite the fact that the selected stimulus type improves reproducibility and that prestimulation reduces habituation, testretest variability persists $(<20 \%)$ which still limits the sensitivity of the method.

In chapter 3 the frequency dependency and amplitude characteristics of GBS in healthy subjects are studied in detail in 12 healthy subjects. Using a binaurally applied sinusoidal modulated current $(0.2$ to $4 \mathrm{~Hz})$ of maximum $1 \mathrm{~mA}$, both lateral and sagittal GBS show a clear optimum between 0.2 and $0.3 \mathrm{~Hz}$ of 1.8 degs/mA on average. With increasing frequency GBS decreases down to nil. This result is discussed in relation to the literature using other analysis techniques that state that GBS does not depend on the stimulus frequency.

Chapter 4 presents the evaluation of possible long-term habituation to repetitive GVS. The previous observed habituation to galvanic stimuli might also persist at longer time intervals and complicate the assessment of vestibular function in time. We study the GBS over a period between 5 days to a maximum of 10 weeks, measuring GBS five times within that period. Habituation indeed accurs always at the first repetition of the test irrespective the time between the tests ( 1 day -2 weeks), pointing to a fast and long lasting learning process. Use of a pre-habituating stimulus (short-term) in combination with a pre-habituating first test (long-term), reduces variability and response decline considerably to a non-significant level. So, by that, the first step to design a useful clinical tool is established as reproducibility is a major pre-requisite.

Chapter 5 evaluates whether the degree of short-term habituation to GVS is related to susceptibility to carsickness. Healthy subjects show normal initial responses and habituate to GVS, rotation, caloric and vehicle motions (ship, car, plane). Carsick subjects often show initial high responses to rotation, caloric and vehicle motions $(1,2)$ and do not habituate effectively (3). In our study we observe that habituation and sensitivity to GVS is not different between the carsick subjects and healthy subjects. This indicates that the sensitivity and fast habituation to GVS are no strong indicators for carsickness, and that carsick subjects show a similar ability to discard the irrelevant, non motion sickness inducing, galvanic stimulus as healthy subjects. 
In chapter 6 we investigate the sensitivity and habituation to GVS in young gymnasts compared to healthy subjects (age matched control group and normative data obtained in our previous studies). In contrast to the population of carsick subjects studied in chapter 5, gymnasts are expected to show increased habituation to vestibular stimull. Literature indeed shows that gymnasts and ballet dancers habituate faster to repetitive rotational stimuli than healthy subjects and also initially have lower and shorter responses. Motor control in the gymnasts in our study proves to be superior to that in untrained age matched subjects by the significant higher composite score on the dynamic posturography test $(p<0.05)$. However, our study shows that sensitivity and habituation to galvanic stimulation does not differ from the healthy subjects.

Chapter 7 describes a study of the various possible sites of excitation by galvanic stimulation. It is generally assumed that in GVS the peripheral receptors are bypassed and the excitation state of Scarpa"s ganglion is directly modified (4-10). The actual conduction course of GVS, however, remains uncertain. To study this in detail GBS is determined in vestibular schwannoma (VS) patients before and after surgical intervention (extirpation of tumour with concomittant westibular neurectomy) and compared with GBS in healthy subjects. In VS-patients the anatomy of the vestibular nerve is severely disturbed (11), and even more after vestibular neurectomy, which could make it possible to differentiate between the vestibular nerve and the vestibular nuclei as sites for retro-labyrinthine gatvanic excitation. Results show no differences in GBS comparing VS-patients with healthy subjects before surgical intervention. After vestibular neurectomy a significant difference in the mean total GBS gain is observed, but GBS is still present after surgery. The latter proves that GVS can excite the central vestibular system in most subjects even when conduction via the vestibular nerve is hampered. The localization of a possible lesion within the peripheral and central part of the vestibular system can probably be determined more accurately as described earlier by Pfaltz et al. (12), by making use of currents with smaller amplitude.

\section{GENERAL DISCUSSION}

GBS or subjective sensations exclusively occut when the electrodes are placed in the vicinity of the labyrinths, which points to a specific vestibular activation. However, the galvanic stimulus is not an exclusive vestibular stimulus and can also lead to tingling sensations at the side of stimulation, taste sensations, light flashes (temporal visual field) and facial muscle activation. Remarkably no auditory sensations are mentioned, which may be explained by the low sensitivity of the auditory system at the stimulus frequencies applied $(<4 \mathrm{~Hz})$.

Out of the stimulus profiles chosen, only continuous1-cosinusoidal GVS results the best reproducible responses. A first exploration of the frequency dependency shows that maximum responses occur at $0.5 \mathrm{~Hz}$. Responses increase linear with stimulus amplitude up to $1 \mathrm{~mA}$ and saturate at about $2 \mathrm{~mA}$. 
In comparison to a previous report in the literature (13) we obseme in a detailed study (chapter 3 ) that the GBS gain depends on the stimulus frequency. GBS gain is maximal between 0.2 and $0.3 \mathrm{~Hz}$ and decreases with frequency up to $4 \mathrm{~Hz}$. The system behaves to some extent non-inear. stimulation at any frequency results in minor but evident responses between 0.2 and $0.3 \mathrm{~Hz}$, designated as a possible "resonance frequency" related to the body dynamics. This would imply that calculating the transfer functions as introduced in chapter 2, implicitly assuming a linear system, is not a valid approach per se. However, the contribution of the response at the "resonance frequency" to the total responise is only small which walidates a inear system analysis as a first approach. Schneider et al. (10) described a low pass frequency characteristic of the galvanic-induced ocular torsion and suggest that the response is dominated by semicircular canal input. As posture control is predominantly influenced by statolith input, our data indicate that the galvanic stimulus (also) excites the statolith input. Apart from the "resonance frequency", we also observe a low pass characteristic. The similarity suggests that the frequency dependence is dominated by the characteristics of the excitation process and not that much by the frequency characteristics of the semicircular canals or statolith organs or mechanics of the eye or body. However, the absence of a "resonance frequency" in the galvanic-induced ocular torsion spectra suggests that the "resonance frequency" may be induced by the mechanics of the body.

To summarize, the hypothesis seems just that low pass frequency characteristics of lateral and sagittal GBS and ocular torsion are determined by the sensitivity of the receptors (probably retromabyrinthine) to the galvanic stimulus. The mechanical characteristics of the body are responsible for the GBS peek between 0.2 and $0.3 \mathrm{~Hz}$. Counteracting this last statement is the fact that the "resonance frequency" is not related to body length or weight. Maybe the remaining variability and the relatively small population are the cause of a missing significant correlation.

lin agreement with Peterson et al. (14), we found that the log transformed torque variance (LTTV) does not vary with stimulus frequency. We show that the frequency dependence depends on the analysis technique: we obtained similar results as Peterson et al. when we applied their analysis technique to our data. This seemingly discrepancy can be explained as follows. Although Peterson et al. corrected their data for the natural body sway, still when using the LTTV as a response measure, all frequency components of the response contribute to the outcome, irrespective the stimulus frequency. This results in a masking of the frequency dependence that is not present when a common spectral analysis (FFT) is performed. We conclude that GBS depends on the stimulus frequency. The "resonance frequency" might point to the impact of body mechanics upon the frequency spectrum. However, the "resonance frequency" of lateral GBS equals sagittal GBS, and the resonance frequency is not related to body length or weight, which sug gests that the frequency dependence of the GBS is perhaps more determined by the frequency sensitivity of the vestibulo-spinal system than the body dynamics. We conclude that the frequency characteristics of GBS have to be taken into consideration in relation to clinical implementation. In our subsequent explorative study we chose $0.5 \mathrm{~Hz}$ as the stimulus frequency, because of the firm responses and good signal to noise ra- 
Hio's. We did not select the "resonance frequency" as primary stimulus because of its yet unclear origin.

Two basic problems hinder a wide clinical application of GVS: variability in the responses and habituation.

\section{Variability}

In our study the test-retest variability of GBS gain (intra-subject variability) is $<20 \%$. Intrasubject variability is larger; GBS ranges from 0.3-5.6 degs/mA (Mean 2.1, SD 1.4, SE 0.4) which may partly be explained by individual differences in the conductivity of the electrical stimulus towards the receptive sites. Variability seems to be more or less a common feature of responses to stimuli of the vestibular system (15). This points to substantial inter-subject variability and many factors that affect the test-retest reproducibility (stimulus conduction, mental state and instruction of the subject, preknowledge etc.).

In the course of our study "dealling with GBS for more than ten years, we reduced the variability considerably by identification of several independent parameters: technical aspects related to positioning and application of the electrodes (minimizing variations in the strength and shape of the electrical field induced in the head), standardizing the subject's instructions, standardizing the position of the feet etc. Despite all these precautions, like in many other clinical vestibular tests, substantial variability remains.

\section{Habituation}

Habituation to GVS is substantial, occurs at the short and long-term, and is surprisingly not frequently mentioned in literature. Our current interpretation of this phenomenon is that at least partly, the response to a galvanic stimulus is affected by negative feedback of the proprioceptive and vestibular system, counteracting the GBS per se. Within the test of 6 consecutive monaural stimuli short-term habituation occurs, which we reduce by a binaural prestimulation. This procedure allows a rellable comparison of the GBS to left and right GVS. Extensive studies using pseudo random stimulation (sham stimulation) do not report this short-term habituation to GVS (13). The habituation to sinusoidal stimulation might reflect the ability of subjects to disregard non-physiological stimuli and learning. Therefore we study the habituation phenomenon in detail by application of sinusoidal stimuli. Apart from short-term habituation, habituation also occurs at the long term: a decline of the outcome of the complete test-result (the average GBS gain of the six consecutive stimuli\} upon repetition after 1 day or more. However, this long-term habituation only occurs always at the first repetition of the test, irrespective the time between the test ( 1 day -2 weeks), pointing to a fast and long lasting learning process. Use of a pre-habituating stimulus (short-term) in combination with a pre-habituating first test (long-term), reduces the habituation considerably to a non-significant level. 
So, by application of the prenabituating stimul, a more consistent cinical tool is established as reproducibility is a major pre-requisite. The test-procedure we developed to assess GBS is then applied as a cinical test (a first test to habituate the system, followed by a second test to quantify the sensitivity (GBS gain)).

\section{Habituation in relation to carsickness and professional gymnasts}

We hypothesize that habituation might also show the ability of the vestibular system to recognize and partially neglect a non-physiological input. A recent paper by Cenciarini et all. (16) supports this hypothesis, indicating that galvanic habituation is a centrally mediated phenomenon associated with the sensory reweighting process, meaning a subject is capable of discarding irrelevant stimuli. For this reason motion sickness could be related to a limited ability to select relevant sensory input and disregard irrelevant sensory information, necessary for good spatial orientation and balance control. We therefore hypothesize that subjects with enhanced susceptibility to carsickness may show a reduced habituation to galvanic stimulli too. However habituation in the susceptible and healthy subjects is not found to be significantly different.

Subsequently, we study gymnasts in which we also use repetitive galvanic stimulation as a model to mimic a sensory conflict with respect to identification of the gravity vector. This is an important factor in motor learning in gymnasts: the vestibular input is modified by the galvanic stimulation suggesting a tilt of the gravity vector, whereas the proprioceptive system detects the correct orientation relative to gravity. As soon as the body moves as a response to the simulated orientation change (GBS), proprioceptive feedback will supply an alerting response to prevent a fall leading to reduction of GBS as a part of a learning process upon repetition. The better the subjects recognize the erroneous galvanic input, the faster habitualion to the GVS occurs. However, in our study results show no difference in mean total habituation to GVS in professional gymnasts versus untrained controls. It might be that in professional gymnasts proprioception is more important in balance control than any other sensory inputs, like GVS. Professional gymnasts thus use past knowledge (acquired in sport training) in the GVS-test.

\section{GVS: site of primary excitation}

The mechanisms and pathways of the galvanic response have been investigated in several papers on GBS $(5,6,17-22)$. We studied this in detail by determining GBS in VS-patients before and after surgical intervention (extirpation of tumour with concomittant vestibular neurectomy) and compared it with GBS in healthy subjects. Before surgical intervention, no differences in GBS were observed comparing VSpatients with healthy subjects This suggests that the galvanic stimulus can bypass the disturbed nerve (11) to excite more centrally located vestibular structures directly. This hypothesis was further supported by the observation that after surgery (including neurectomy of SVN and IVN) still a GBS exists. 
Excitability (GBS) may be a sign of functionality of the peripheral and/or central vestibular system. However, a lack of excitability points to a severe function loss of the vestibular nerve, but does not reflect the absence of central vestibular functionality.

However, in the patients with large tumours excitability is not affected by surgery; in these patients the excitability pre-operative is already relatively small, which suggests that the remaining excitability arises from central excitation only (root entry zone of the vestibular nuclei?). Remarkably two patients with small tumours and a low excitability close to the shown excitability in the patients with large tumours, show a 100\% reduction of the response. Apparently no excitation of the central vestibular system occurs in these two patients.

So, the picture is complex and the contribution of central excitation to the galvanic response depends on several yet unknown factors. In any case, our data support the hypothesis that central excitation occurs in many patients but not in all.

We can only speculate about the explanation. The poor central excitation in the large tumours might be explained by dysfunction in conduction capacity of the root entry zone by compression. A major problem is explaining the lack of central excitation in some of the patients with small tumours. We confirmed this observation in our current clinical practice. We seem to be left with the hypothesis that a major factor of the large interindividual variability of the galvanic responses, together with the variable contribution of central excitation, may arise from basic differences in the conduction properties of the scull and surrounding tissues. So despite the observation that the GBS to some extent reflects the function of the peripheral vestibular nerve, the variable contribution of the central excitation hampers a simple clinical interpretation of the GBS. Pfaltz et al. (12) suggested already many years ago that low currents only reach the peripheral vestibular system, whereas higher currents additionally stimulate central parts. This would imply that the 2 mA-stimulus, used in this study, might be too high to allow discrimination. In conclusion, we observe that excitability is a sign of functionality of the peripheral and/or central vestibular system. However, a lack of excitability points to a severe function lass of the vestibular nerve, but does not reflect the absence of central vestibular functionality. 


\section{REFERENCES}

1. Calkins DS, Reschke MF, Kennedy RS, Dunlop WP. Reliability of provocative tests of motion sickness susceptibility. Aviat Space Environ Med 1987:58(9 Pt 2):A50-4.

2. Mallinson Al, Longridge NS. Motion sickness and vestibular hypersensitivity. The Joumal of Otolaryngology $2002 ; 31(6): 381-385$

3. Reason JT. Motion sickness adaptation: a neural mismatch model. J.R. Soc. Med. 1987;71:819. 829.

4. Meran A. Differential diagnosis of cerebellopontine angle tumours with special reference to the galvanic test. Clin Otolaryngol 1977;2(3):221-31.

5. Courjon JH, W. P, D.W. S. Vestibular nerve and nuclei unit responses and eye movement responses to repetitive galvanic stimulation in the labyrinth in the rat. Exp Brain Res $1987 ; 66: 41-8$.

6. Lowenstein OJ. The effect of galvanic polarization on the impulse discharge from sense endings in the isolated labyrinth of the thornback ray (raja claviata). Physiol 1955;127:104-17.

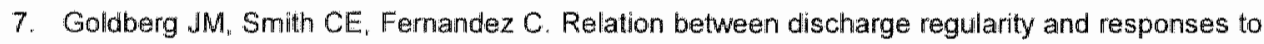
externally applied galwanic currents in vestibular nerve afferents of the squirrel monkey. J Neurophysiol 1984;51(6):1236-56.

8. Pfaltz $C R$ Koike Y. Galvanic test in central vestibular lesions. Acta Otolaryngol 1968;65(1):1618.

9. Pfaltz CR. [Proceedings: Studies on the diagnostic significance of the galwanic test in acoustic neurinoma]. Arch Klin Exp Ohren Nasen Kehlkoptheilkd 1973;205(2):130-4.

10. Schneider E, Glasauer S, Dieterich M. Central processing of human ocular torsion analyzed by galvanic vestibular stimulation. Neuroreport 2000,11(7):1559-63.

11. Hulshof $J H$, Hilders CG, Baarsma EA. Vestibular investigations in acoustic neuroma. Acta Otolaryngol 1989;108(\#-2):38-44.

12. Pfaltz CR. The diagnostic importance of the galvanic test in otoneurology. Pract Otorhinolaryngol (Basel) 1969:31(4):193-203.

13. Magnusson $M$, Johansson $R$, Wiklund $J$. Galwanically induced body sway in the anteriorposterior plane. Acta Otolaryngol 1990;110(1-2):11-7.

14. Petersen H, Magnusson M, Fransson PA, Johansson R. Vestibular stimulation perturbs human stance also at higher frequencies. Acta Otolaryngol Suppl 1995;520 Pt 2:443-6.

15. MacDougall HG, Brizuela AE, Burgess AM, Curthoys IS. Between-subject variability and withinsulject rellability of the human eye-movement response to bilateral galvanic (DC) vestibular stimulation. Exp Brain Res 2002;144(1):69-78.

16. Cenciarini M, Peterka RJ, Horak FB. Habituation to galvanic vestibular stimulation depends on sensory reweighting. J Vestib Res 2001/2002;11(3-5):288.

17. Britton TC, Day BL. Browin P, Rothwell JC. Thompson PD, Marsden CD. Postural electromyographic responses in the arm and leg following galvanic vestibular stimulation in man. Exp Brain Res 1993:94(1):143-51. 
18. Day $B L$, Severac Cauquil $A_{8}$ Bartolomei $L$, Pastor MA, Lyon IN. Human body-segment tilts induced by galvanic stimulation: a vestibularly driven balance protection mechanism. J Pliysiol $1997,500(\mathrm{Pt} 3): 6661-72$.

19. Johansson R, Magnusson M, Fransson PA. Galvanic vestibular stimulation for analysis of postural adaptation and stability. IEEE Trans Biomed Eng 1995;42(3):282-92.

20. Day BL, Pastor MA, Bartolomei $L$, Bonato $C$. Influence of conflicting sensary information on vestibular-induced postural adjustments in man. Jpn J Physiol 1995;45(2):S333.

21. Coats $A C$. The sinusoidal galvanic body-sway response. Acta Otolaryngol 1972; 74(3):155-62.

22. Goldberg JM, Femandez C, Smith CE. Responses of vestibular-nerve afferents in the squirrel. monkey to externally applied galvanic currents. Brain Res $1982 ; 252(1): 156-60$. 

Chapter 9

Samenvatting 
Deze studie is ontwikkeld om galvanisch geinduceerde lichaamszwaai (GLZ) te onderzoeken en een gestandaardiseerde methode te onwwikelen voor een reproduceerbare kwantificering van GLZ. Een algemene inteiding in de relevante literatuur, het doel van de studie en inhoud van de verscheidene hoofdstukken is weergegeven in de introductie (hoofdstuk 1).

Hoofdstuk 2 beschrijft de testopsteling en de pilot-studie, waarbij de galwanische vestibulaire stimulatie (GVS) methode, welke de beste reproduceerbare GLZ geeft, wordt gedefinieerd. Dit blijkt een continue 1 -cosinus stimulatie van $0.5 \mathrm{~Hz}$ en $2 \mathrm{~mA}$ te zijn en wordt verwolgens gebruikt voor het verdere onderzoek in onze normatieve studie. Een binaurale prestimulatie vermindert de korte termijn habituatie (gewenning) aan daaropwolgende stimuli. Ondanks het feit dat de geselecteerde stimulus de reproduceerbaarheid verbetert en dat de binaurale prestimulatie habituatie vermindert, blift enige variabiliteit bestaan $(<20 \%)$, wat de sensitiviteit van de GVS-methode beperkt.

In hoofdstuk 3 wordt een studie raar de frequentie- en amplitudeafhankelijkheid wan GLZ verricht in 12 gezonde proefpersonen. Er wordt gebruik gemaakt van een binaurale continue sinusoidale stimulus $(0.2-4 \mathrm{~Hz})$ van maximaal $1 \mathrm{~mA}$ om de frequentieafhankelijkheid van zowel laterale als sagittale GLZ te bepalen. De gemiddelde GLZ neemt bij toenemende frequentie eerst toe tot een maximum van $1.8 \% \mathrm{~mA}$ bij stimulatie tussen 0.2 en $0.3 \mathrm{~Hz}$ en neemt vervolgens bij toenemende frequentie af tot vrijwel nul. Opmerkelijk is de piek in de responsie tussen 0.2 en $0.3 \mathrm{~Hz}$ die steeds optreedt bij alle stimulatiefrequenties boven $1 \mathrm{~Hz}$. Mogelijk is dit de "resonantiefrequentie", gerelateerd aan de dynamica van het lichaam. Dit suggereert dat toepassing van een Fourier-analyse, welke uitgaat van een lineair systeem, niet per definitie de juiste benadering is. De bijdrage van de respons bij de "resonantiefrequentie" aan de totale respons is echter slechts klein, wat een hineaire systeemanalyse als eerste benadering valideert. Schneider et al. (1) beschreven dat de overdrachtsfunctie van galvanisch geinduceerde oogtorsie zich als een low-pass filter gedraagt en suggereerden dat de respons gedomineerd wordt door input van de semicirculaire kanalen. De inwloed van het vestibulaire systeem op de houdingscontrole verloopt grotendeels vanuit het statolietensysteem, waaruit blijkt dat GVS ook de input van de statalieten beïnvloedt. Behoudens de piekresponsie tussen 0.2 en $0.3 \mathrm{HZ}$ ("resonantiefrequentie") gedraagt de overdrachtsfunctie van de GLZ zich net als die van de galvanisch geïnduceerde oogtorsie als een low-pass filter. Dit suggereert dat de frequentieafhankelijkheid gedomineerd wordt dooi de eigenschappen van het excitatie proces en niet zozeer door de frequentie eigenschappen van de semicirculaire kanalen- of het statolietensysteem, of mechanica van oog- of lichaamsbewegingen. Echter: juist de afwezlgheid van een "resonantiefrequentie" in de galvanisch geinduceerde oogtorsie spectra suggereert dat de "resonantiefrequentie" bij de GLZ primair geassocieerd is met de mechanische eigenschappen van de lichaamsbewegingen. Samenvattend. lijkt de hypothese gerechtvaardigd dat de low-pass frequentiekarakteristiek van sagittaal en lateraal GLZ en oogtorsie bepaald worden door de gevoeligheid van de receptieve structuren (waarschijnlijk retro-labyrinthair) voor de galvanische stimulus en dat de mechanische eigenschappen van het lichaam verantwoordelijk zijn voor de piekresponsie tussen 
0.2 en $0.3 \mathrm{~Hz}$ bij de $\mathrm{GLZ}$. Tegen het laatste pleit echter dat de "resonantiefrequentie" zelf niet samenhangt met lichaamslengte en lichaamsgewicht. Mogelijk echter dat de resterende variabiliteit en de beperkte populatiegrootte debel zijm aan het ontbreken van een significante correlatie.

Net als Petersen et al. (2), objectiveerden we dat de log getransformeerde torsie variantie (LTTV) niet verandert bij wisselende stimulus frequentie. Blijkbaar is de gekozen analyse-methode cruciaal bij de bepaling van de frequentieafhankelijkheid. Deze schijnbare discrepantie kan als volgt worden verklaard. Ondanks het feit dat Petersen et al. de LTTV corrigeerden voor de natuurlijke lichaamszwaai, dragen alle frequentiecomponenten van de respons bij tot de uiteindelijke respons, ongeacht de stimulus frequentie. Dit resulteert in een maskering van de frequentieafhankelijkheid welke niet aanwezig is als een spectraalanalyse wordt uitgevoerd (FFT). We concluderen dat de frequentie eigenschappen van de GLZ in beschouwing moeten worden genomen bij de klinische implementatie. In onze volgende exploratieve studie werd $0.5 \mathrm{~Hz}$ als stimulusfrequentie gekozen, omdat deze een duidelijke respons en een goede signaal-ruis verhouding laat zien. We selecteerden niet de "resonantiefrequentie", als primaire stimulusfrequentie, omdat de origine ervan nog onduidelijk blijft.

Twee basale problemen beperken een brede klinische toepassing van GVS: variabilliteit van de respons en habituatie. Deze aspecten zijn vooral in hoofdstuk 4,5 en 6 beschreven.

\section{Variabiliteit}

In onze studie is de test-retest variabiliteit van de GLZ gain (intra-subject variabiliteit) minder dan $20 \%$. De inter-subject variabiliteit is groter; $G L Z$ varieert van $0.3-5.6 \% \mathrm{~mA}$ (gemiddeld 2.1, SD 1.4, SE 0.4) wat deels verklaart kan worden door inter-individuele verschillen in geleidbaarheid van de electrische stimulus naar de receptieve structuren. Variabiliteit lijkt een min of meer normaal verschijnsel bij het vestibulaire systeem (3), wat wijst op substantiêle inter-subject variabiliteit en vele factoren die test-retest reproduceerbaarheid beïnvloeden (geleidbaarheid van de stimulus, mentale toestand van de proefpersoon, mentale instructie, voorkenmis, etc.). Tijdens dit gehele onderzoek, na de GLZ gedurende meer dan tien jaar te hebben bestudeerd, hebben we de variabiliteit aanzienlijk weten te reduceren door identificatie van enige parameters: technische aspecten gerelateerd aan pasitionering en applicatie van de elektrodes (minimaliseren van de variaties van de sterkte vorm van het gegenereerde elektrische veld geinduceerd in het hoofd), standaardisatie van de stand en positie van de voeten etc. Ondanks al deze voorzorgsmaatregelen blift, zoals bij vele andere vestibulaire testen "een substantiële variabiliteit bestaan. 
In hoofdstuk 4 wordt het habituatie fenomeen bij GVS beschreven. Habituatie aan GVS is substantieel, heeft een korte en lange termijn effect, en wordt verrassend genoeg niet frequent in de literatuur vermeld. Onze huidige interpretatie van dit fenomeen is dat op zijn minst gedeeltelijk, de respons van een galvanische stimulus ook wordt veroorzaakt door een negatieve feedback van het proprioceptieve en vestibulaire systeem, welke tegen de GLZ inwerkt. Echter, habituatie is mogelijk ook een gevolg van het vermogen om niet-fysiologische stimuli te negeren door centrale leerprocessen.

Binnen de test van 6 opeenvolgende monaurale stimuli treedt korte termijn habituatie op. welke beduidend minder is na binaurale prestimulatie. De prestimulatie maakt daardoor een vergelijking tussen $G L Z$ door stimulatie links en rechts mogelijk. Uitgebreide studies, waarbij "pseudo-random" stimulaties ("sham" stimulatie) worden gebruikt, beschrijven geen korte termijn habituatie aan GVS (4). Om deze reden bestudeerden we het habituatie fenomeen in detail middels herhaalde sinusoidale stimulatie. Afgezien van korte termijn habituatie, treedt habituatie ook op lange termijn op: een afname van de respons van 1 complete test (de gemiddielde GLZ van 6 opeenvolgende stimuli) bij herhaling van de test ma 1 dag of meer. Deze lange termijn habituatie treedt alleen en altijd op na de eerste herhaling van de test, ongeacht het tijdsinterval tussen de testen ( 1 dag -2 weken), wat duidt op een snel lleerproces dat ook lang effect sorteert.

De toepassing van de prehabituerende stimulus (korte termijn) in combinatie met een pre-habituerendle eerste test (lange termijn), leidt tot een goed reproduceerbare test.

In hoofdstuk 5 wordt de gevoeligheid voor en korte termijn habituatie aan GVS bestudeerd bij personen gevoelig voor wagenziekte.

Gezonde proefpersonen tonen een normale initiële respons en habitueren aan GVS, rotatie, calorische stimulatie en bewegingen van een voertuig (auto, schip, vliegtuig). Personen gevoelig voor wagenziekte tonen vaak een versterkte initiële respons aan rotatie, calorische stimulatie en bewegingen van een voertuig $(5,6)$ en habitueren niet effectief aan de eerder gemelde stimuli (7). Wij stellen vast dat gevoeligheid voor en korte termijn habituatie aan GVS niet verschilt bij gezonde proefpersonen en personen gevoelig voor wagenziekte.

Dit betekent dat de gevoeligheid voor en korte termijn habituatie aan GVS geen sterke indicatoren zijn voor wagenziekte, en dat proefpersonen gevoelig voor wagenziekte hetzelfde vermogen hebben om een irrelevante, niet bewegingsziekte-provocerende galvanische stimulus te negeren als gezonde proefpersonen.

In hoofdstuk 6 wordt de gevoeligheid voor en korte termijn habituatie aan GVS bestudeerd bij turnsters en ongetrainde proefpersonen (leeftijdsgenoten en normatieve data verkregen in onze vorige studie). In tegenstelling tot de proefpersonen gevoelig voor wagenziekte, welke bestudeerd werden in hoofdstuk 5 , verwachten we dat turnsters een versnelde habituatie laten zien aan vestibulaire stimuli. In de literatuur $(8,9)$ wordt inderdlaad beschreven dat turnsters en ballerina's sneller habitueren aan rotatoire stimuli dan ongetrainde proefpersonen en ook initiële lagere en korter durende responsies hebben. 
In onze studie wordt geobjectiveerd dat fumsters een significant hogere "composite scow $\mathrm{re}^{\mathrm{s}}$ hebben dan ongetrainde leeftijdsgenoten bij de dynamische posturografie test $(\rho<0.05)$. Echter, onze studie laat geen verschil in gevoeligheid woor en korte termin habituatie aan GVS zien $(p>0.05)$ bil vergelijking van turnsters met ongetrainde proefpersonen.

Hoofdstuk 7 beschrijft een studie naar de mogelijke locaties van primaire excitatie bij GVS.

Er wordt algemeen gedacht dat in GVS de perifere receptoren overgeslagen worden en de mate van excitatie van het ganglion van Scarpa direct wordt beinvloed $(1,10-16)$. De werkelijke geleidingsroute van GVS blift echter onzeker. Om dit in detail te bestuderen werd GLZ bepaald in patienten met een vestibulair schwannoom (VS) voor en na chirurgische interventie (extirpatie van de tumor met neurectomie van de nervus vestibularisj en vergeleken met GLZ in gezonde proefpersonen. In patienten met een VS is de anatomie van de nervus vestibularis sterk verstoord (17), temeer na een neurectomie van de nervus vestibularis, waardoor het mogelijk zou kunnen zijn te differentiëren tussen de nervus vestibularis en de vestibulaire kernen als mogelijke oorsprong van galvanische excitatie. De resultaten latten geen verschil zien tussen GLZ in patiënten met een VS en gezonde proefpersonen voor chirurgische interventie. Na neurectomie van de nervus vestibularis is de GLZ in patiënten met een VS en gezonde proefpersonen significant verschillend, maar GLZ is nog steeds aanwezig na de ondergane operatie. GLZ kan dus mogelijk een teken zijn van functionaliteit van het perifere en/of centrale vestibulaire systeem. Een gebrek aan prikkelbaarheid (GLZ) laat echter zien dat het perifere systeem ernstig verlies van functionaliteit heeft, maar wijst niet op een afwezigheid van functionaliteit het centrale vestibulaire systeem.

Echter, in patienten met een grote tumor (VS) wordt de prikkeibaarheid niet significant beïnvloed door de operatie. Bij deze patiënten is de pre-operatieve prikkelbaarheid al relatief klein, wat suggereert dat de overgebleven prikkelbaarheid enkel ontstaat vanuit centrale excitatie (root entry zone wan de vestibulaire kernen?). Opmerkelijk genoeg laten twee patienten met een kleine tumor en een lage prikkelbaarheid, bijna vergelijkbaar met de prikkelbaarheid bij patiënten met grote tumoren, een 100\% afname zien van de respons. Blijkbaar treedt geen excitatie van het centrale vestibulaire systeem op bij deze twee patienten.

Het beeld is dus gecompliceerd en de bijdrage van de centrale excitatie aan de galvanische respons hangt af van meerdere, nog onbekende, factoren. In ieder geval spreken onze data voor de hypothese dat centrale excitatie optreedt in veel, maar niet in alle pathënten. Pfaltz et al. (18) suggereerde reeds vele jaren geleden dat bij gebruikmaking van een lage stroomsterkte alleen het perifere vestibulaire systeem bereikt kan worden, terwij! een hogere stroomsterkte daamaast ook het centrale westibulaire systeem kan bereiken. Dit kan betekenen dat de stroomsterkte van $2 \mathrm{~mA}$, welke toegepast wordt in deze studie, misschien te hoog is om discriminatie mogelijk te maken. 


\section{REFERENTIES}

1. Schneider E, Glasaver S. Dieterich M. Central processing of human acular torsion analyzed by galvanic vestibular stimulation. Neurareport 2000;11(7):1559-63.

2. Petersen $H$, Magnusson $M_{*}$ Fransson $P A$, Johansson $R$. Vestibular stimulation perturbs human stance also at higher frequencies. Acta Otolaryngol Suppl 1955,520 Pt 2443-6.

3. MacDougall HG, Brizuela AE, Burgess AM, Curthoys IS. Between-subject variability and withinsubject reliability of the human eye-movement response to bilateral galvanic (DC) vestibular stimulation. Exp Brain Res 2002;144(1):69-78.

4. Magnusson $M$, Johansson $R$, WikJund $J$. Galvanically induced body sway in the anteriorposterior plane. Acta Otolaryngol 1990;110(1-2):11-7.

5. Calkins DS, Reschke MF, Kennedy RS, Dunlop WP. Reliability of provocative tests of motion sickness susceptibility. Awiat Space Environ Med 1987;58(9 Pt 2):A50-4.

6. Mallinson AI, Longridge NS. Motion sickness and vestibular hypersensitivity. The Journal of Otolaryngology 2002,31(6):381-385.

7. Reason JT. Motion sickness adaptation a neural mismatch model. J.R. Soc. Med. 1987;71:819829

8. Vuillerme $\mathbb{N}$, Teasdale $\mathbb{N}_{\text {"Nougier }} \mathrm{V}$. The effect of expertise in gymnastics on proprioceptive sensory integration in human subjects Neuroscience Letters 2001;311:73-76.

9. Vuillerme N, Danion F, Marin L, Boyadjian A, Prieur JM, Weise $\mathbb{1}$, et all. The effect of expertise in gymnastics on postural control. Neurosci Lett 2001;303(2):83-6.

10. Pfaltz CR, Koike Y. Galvanic test in central vestibular llesions. Acta Otolaryngol 1968;65(1):161 w 8.

11. Courjon JH, W. P, D.W. S. Vestibular nerve and nuclei unit responses and eye movement responses to repetitive galvanic stimulation in the labyrinth in the rat. Exp Brain Res $1987 ; 66: 41-8$.

12. Lowenstein OJ. The effect of galvanic polarization on the impulse discharge from sense endings in the isolated labyrinth of the thornback ray (raja claviata). Physiol 1955;127:104-17.

13. Goldberg JM, Smith CE, Fernandez $\mathrm{C}$. Relation between discharge regularity and responses to externally applied galvanic currents in vestibular nerve afferents of the squirrel monkey. $J$ Neurophysiol 1984; $51(6): 1236-56$.

14. Watanabe $Y$, Mizukoshi $K$, Ohi $H$, Yasuda $K$, Ohasi $N$, Kobayashi $H$. Retro-labyrinthine disorders detected by galvanic body sway response in routine equilibrium examinations. Acta Oto-Laryngol. Suppl. 1989:468:343-348.

15. Meran A. Differential diagnos is of cerebellopontine angle tumours with special reference to the galvanic test. Clin Otolaryngol 1977:2(3):221-31

16. Pfaltz CR. [Proceedings: Studies on the diagnostic significance of the galvanic test in acoustic neurinoma]. Arch Klin Exp Ohren Nasen Kehlkopfheilkd 1973;205(2):130-4.

17. Hulshof JH, Hilders CG, Baarsma EA. Vestibular investigations in acoustic neuroma. Acta Otolaryngol 1989:108(1-2):38-44.

18. Pfaltz CR. The diagnostic importance of the galvanic test in otoneurology. Pract Otorhinalaryngol (Basel) 1969;31(4):193-203. 


\section{ACKNOWLEDGEMENTS}

This dissertation could not have been accomplished without the advise, support and encouragement of a lot of people. I hereby would like to express my appreciation for these people.

First of all prof. dr. H. Kingma, dear Herman, many years ago our paths crossed and you made me enthusiastic about vestibular research. The many years of working together on this project have been a great joy and I will always treasure this valuable experience. You are a great motivator, and good friend. With all your chaos, humor and a great deal of knowledge you are irreplaceable.

Dr. R.J. Stokroos, dear Robert, your otological and vestibular knowledge as an otorhinolaryngologist made your guidance and co-supervision very valuable. Thank you for all suggestions and your support.

All subjects that participated in the experiments I would like to thank again; without them this thesis would never have been published in the first place.

Prof. dr. M. Magnusson, thank you for inviting us to your vestibular laboratory and guidance through the "labyrinth" of the methods of galvanic vestibular stimulation.

Drs. J. van Twisk, dear Jaap, you were the one who initiated this research-project and took the hardest steps, thank you for all your effort.

Thanks to all students, Rob Boumans, Cindy Penners, Maikel van de Laar, Rosemiek Eterman and Martijn Castelijns for their participation in data-aquisition and enthousiastic effortt.

I would also like to thank Ellen Akkermans, Sophie Paredis and Nadia Hendrice, ENGtechnicians at the department of ORL for their great and indispensable contribution in this work.

Thank you Iwan de Jong and Joep Orbons, computer-technicians of the ENG-laboratory for development of all equipment and "keeping the motors running".

All of my collegues, Jan Wouter, Gerl-Jan, Noortje, Ewa, Ivette, Stijn, Willeke and Isabelle: the far right computer-corner in our room is vacant again... It has been a great laugh all those years and 1 will surely miss working with you all.

Special thanks to my parents for always being interested and for their ongoing support.

Dear Martijn. I would like to express my deepest appreciation for you, always standing next to me, taking all other burdens off my shoulders. Just being you, you proved to be the most valuable... 



\section{CURRICULUM VITAE}

Susanne Balter was born in Sittard, The Netherlands, on February 2 nd 1972 . After attending the Serviam Lyceum in Sittard, she graduated (atheneum-beta) in 1990. In 1992 she obtained her propaedeutic diploma in Health Sciences and Medicine at the University Maastricht. She graduated in Medicine in 1996. This was followed by a 6-month research period at the Balance Disorders Unit of the Rayal Prince Alfred Hospital in Sydney, Australia. In 1998 she qualified as a medical doctor.

From 1999-2004 she worked as a resident at the department of Otorhinolaryngology, Head and Neck Surgery at the University Hospital of Maastricht. There she carried out the research project at the vestibular department which is reported on in this thesis. In May 2004, she was registered as an ENT-surgeon.

From June 2004 she is working as an ENT-surgeon at the Jeroen Bosch Hospital in 's Hertogenbosch. 